\title{
MASTER
}

\section{A Sensitivity Analysis of SPURR}

ats

Robert E. Witholder
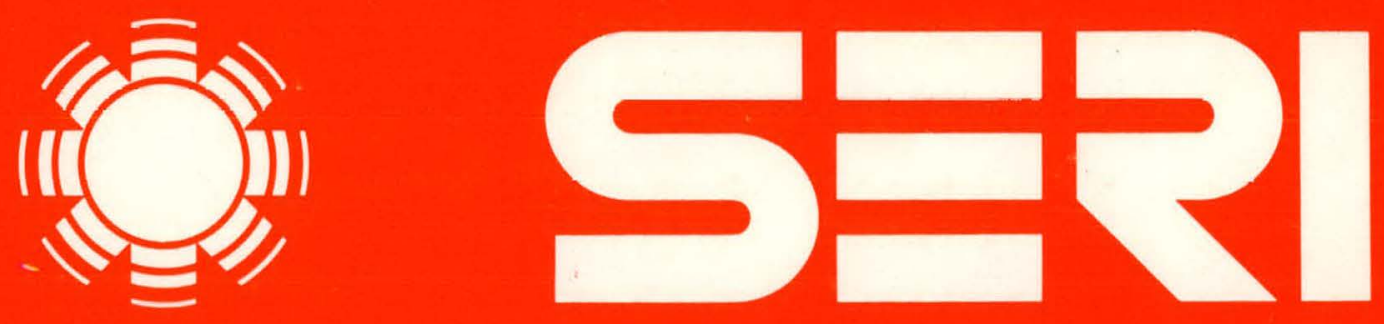

Solar Energy Research Institute

A Division of Midwest Research Institute

1617 Cole Boulevard

Golden, Colorado 80401

Operated for the

U.S. Department of Energy

under Contract No. EG-77-C-01-4042 


\section{DISCLAIMER}

This report was prepared as an account of work sponsored by an agency of the United States Government. Neither the United States Government nor any agency Thereof, nor any of their employees, makes any warranty, express or implied, or assumes any legal liability or responsibility for the accuracy, completeness, or usefulness of any information, apparatus, product, or process disclosed, or represents that its use would not infringe privately owned rights. Reference herein to any specific commercial product, process, or service by trade name, trademark, manufacturer, or otherwise does not necessarily constitute or imply its endorsement, recommendation, or favoring by the United States Government or any agency thereof. The views and opinions of authors expressed herein do not necessarily state or reflect those of the United States Government or any agency thereof. 


\section{DISCLAIMER}

Portions of this document may be illegible in electronic image products. Images are produced from the best available original document. 
Printed in the United States of America Available from:

National Technical Information Service

U.S. Department of Commerce

5285 Port Royal Road

Springfield, VA 22161

Price:

Microfiche $\$ 3.00$

Printed Copy $\$ 6.50$

\begin{abstract}
NOTICE
This report was prepared as an account of work sponsored by the United States Government. Neither the United States nor the United States Department of Energy, nor any of their employees, nor any of their contractors, subcontractors, or their employees, makes any warranty, express or implied, or assumes any legal liability or responsibility for the accuracy, completeness or usefulness of any information, apparatus, product or process disclosed, or represents that its use would not infringe privately owned rights.
\end{abstract}


ROBERT E. WI THOLDER

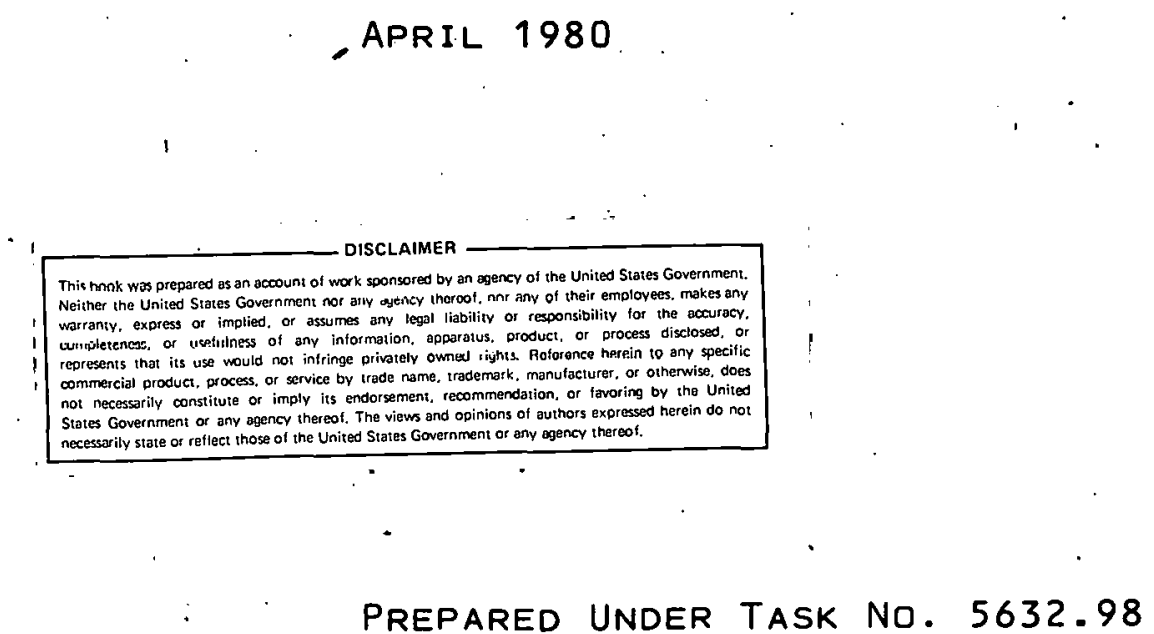

PREPARED UNDER TASK NO. 5632.98

Solar Energy.Research Institute

1536 Cole Boulevard Golden. Colorado 80401

A Division of Midwest Research Institute

Prepared for the U.S. Department of Energy Contrast No. EG.77:C.01.4042 
THIS PAGE

WAS INTENTIONALLY LEFT BLANK 


\section{FOREWORD}

This report documents a portion of the research output of Task 5229, "Solar Modeling Forum," in the Economic Analysis Branch of the Analysis Division. For this sensitivity analysis, a critical parameter in the model was identified and its value changed while all other parameters remained constant. Results were evaluated in terms of intuitive expectations.

The author acknowledges the contributions and critical reviews of Mark Wallenrod, a graduate intern from the University of Pennsylvania.

\section{Approved for:}

SOLAR ENERGY RESEARCH INSTITUTE

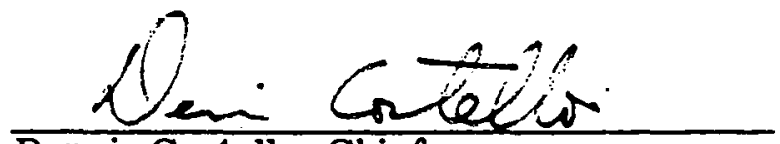

Dennis Costello, Chief

Economic Analysis Branch 


\section{THIS PAGE}

WAS INTENTIONALLY

LEFT BLANK 
Sensitivity analysis was performed on the agricultural and industrial process heat and utility market sectors of the SPURR (System for Projecting the Utilization of Renewable Resources developed by the MITRE Corporation) model which utilized the DPR baseline scenario. The objective of this sensitivity analysis is to determine if variations in solar system capital cost, operation and maintenance cost, and fuel cost (for biomass only) correlate with "common sense" and do not offend basic intuition. In general, this effort is part of a much larger issue: validation of SPURR.

Variations of the factors were evaluated for the following output parameters (others are available):

- accumulated installed systems,

- annúal energy production,

- accumulated capital cost, and

- accumulated life-cycle cost.

An analysis of the resul ts is presented for three criteria: (1) type of relationship, (2) sense, and (3) sensitivity.

The type of relationship indicates whether the change in penetration is linear or nonlinear with respect to a change in a given variable, while sense attemp ts to evaluate the direction of change with respect to an intuitive feeling about penetration. Sensitivity is the ratio of percentage change in penetration versus a percentage change in a given factor (e.g., capital cost).

This study has practical applications for engineering improvements in solar technologies and is useful as a planning tool in the $R \& D$ allocation process. The resul ts of the analysis for the variables studied indicate that SPURR simulation is consistent with intuitive effects for these variables.

Further research efforts will be conducted after a coding problem encountered in the output report of the SHACOB component is corrected. A similar analysis will be performed in this sector.

SPURR must also be modified so that variations in system lifetime can be included. Presently, sensitivity analysis of system lifetime will produce results that are counterintuitive and are the result of the economic equations in the model that cannot handle systems with different lifetimes. Comparisons between systems require a common time basis, including a common year for cost comparison and a common operating period. 
THIS PAGE WAS INTENTIONALLY LEFT BLANK 


\section{TABLE OF CONTENTS}

$\underline{\text { Page }}$

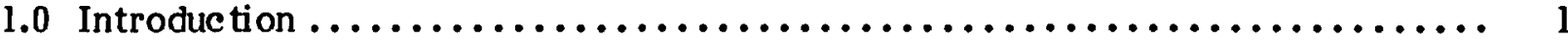

2.0 The SPURR Model................................. 5

2.1 Process Heat Component $\ldots \ldots \ldots \ldots \ldots \ldots \ldots \ldots \ldots \ldots \ldots \ldots \ldots \ldots \ldots \ldots$

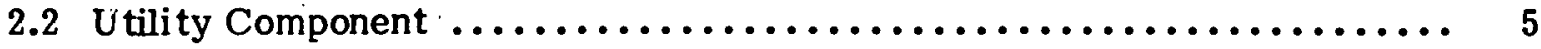

3.0 Capital Cost Sensitivity Analysis $\ldots \ldots \ldots \ldots \ldots \ldots \ldots \ldots \ldots \ldots \ldots \ldots \ldots$

3.1 Process Heat System Penetration vs. Capital Cost

Variation ....................................... 14

3.2 Solar Thermal Utility Penetration vs. Capital Cost

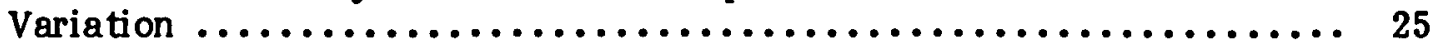

3.3 Photovol taic Utility Penetration vs. Capital Cost .................. 25

3.4 Biomass Systems Penetration vs. Capital Cost. . . . . . . . . . . . . . 36

3.5 WECS Utility Penetration vs. Capital Cost.................... 42

3.6 OTEC Systems Penetration vs. Capital Cost .................. 42

4.0 Annual O\&M Sensitivity Analysis $\ldots \ldots \ldots \ldots \ldots \ldots \ldots \ldots \ldots \ldots \ldots \ldots \ldots \ldots \ldots$

4.1 Process Heat Systems Penetration vs. Annual O\&M Cost............ 56

4.2 Solar Thermal Utilities Penetration vs. Annual O\&M Cost........... 56

4.3 Photovoltaics Utilities Penetration vs. Annual O\&M Cost ........... 67

4.4 Biomass Systems Penetration vs. Annual O\&M Cost .............. 73

4.5 WECS Utility Penetration vs. Annual O\&M Cost ................ 73

4.6 OTEC Systems Penetration vs. Annual O\&M Cost............... 85

5.0 Biomass Fuel Cost Sensitivity Analysis $\ldots \ldots \ldots \ldots \ldots \ldots \ldots \ldots \ldots \ldots \ldots \ldots \ldots \ldots$

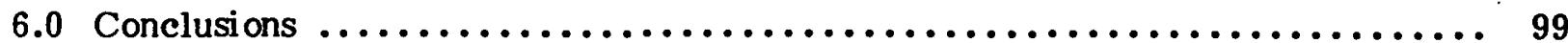

6.1 Capital Cost....................................... 99

6.2 Operating and Maintenance Costs $\ldots \ldots \ldots \ldots \ldots \ldots \ldots \ldots \ldots \ldots \ldots \ldots \ldots \ldots 100$

6.3 Fuel Cost: Biomass $\ldots \ldots \ldots \ldots \ldots \ldots \ldots \ldots \ldots \ldots \ldots \ldots \ldots \ldots \ldots \ldots \ldots \ldots \ldots$

6.4 Summary........................................... 101

7.0 References $\ldots \ldots \ldots \ldots \ldots \ldots \ldots \ldots \ldots \ldots \ldots \ldots \ldots \ldots \ldots \ldots \ldots \ldots \ldots \ldots \ldots$ 
THIS PAGE

WAS INTENTIONALLY

LEFT BLANK 


\section{LIST OF TABLES}

Page

1-1 Sensitivity Analysis $(\%$ Variations) $\ldots \ldots \ldots \ldots \ldots \ldots \ldots \ldots \ldots \ldots \ldots$

2-1 Process Heat Baseline Assumptions in SPURR ................ 8

2-2 Electric Technologies ............................... 9

2-3 Synthetic Fuels and Product Technology ...................... 10

2-4 Utility Synthetic Produc ts Baseline Assumptions in SPURR and

Grouping per Technology Category 


\section{THIS PAGE}

\section{WAS INTENTIONALLY \\ LEFT BLANK}




\section{LIST OF FIGURES}

$\underline{\text { Page }}$

2-1 SPURR Flow Diagram $\ldots \ldots \ldots \ldots \ldots \ldots \ldots \ldots \ldots \ldots \ldots \ldots \ldots \ldots \ldots \ldots \ldots \ldots \ldots$

2-2 MITRE Market Share Function ........................... 7

3-1 Process Heat, \% Capital Costs Change vs. Cumulative

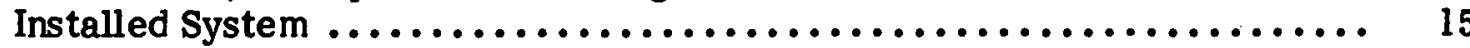

3-2 Process Heat, \% Capital Costs Change vs. Annual Energy

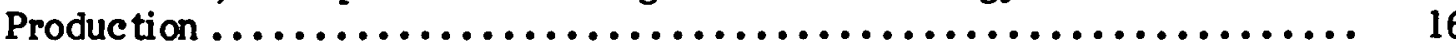

3-3 Process Heat, \% Capital Costs Change vs. Accumulated Capital Cost ...................................... 17

3-4 Process Heat, \% Capital Costs Change vs. Accumulated Lif - Cycle Cost .................................... 18

3-5 Process Heat, $\%$ Capital Costs Change vs. Cumulative Installed Systems .......................................... 19

3-6 Process Heat, $\%$ Capital Costs Change vs. Annual Energy Production .......................................... 20

3-7 Process Heat, \% Capital Costs Change vs. Accumulative Capital Costs.......................................

3-8 Process Heat, \% Capital Costs Change vs. Accumulated Life-Cycle Costs.....................................

3-9 Percent Change in Process Heat Variables vs. $\%$ Change in

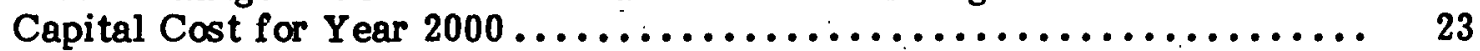

3-10 Percent Change in Process Heat Variable vs. \% Change in Capital Cost for Year 2000 (Accumulated Life Cycle Cost) ........... 24

3-11 Solar Thermal, \% Capital Costs Change vs. Cumulative Installed System

3-12 Solar Thermal, \% Capital Costs Change vs. Annual Energy

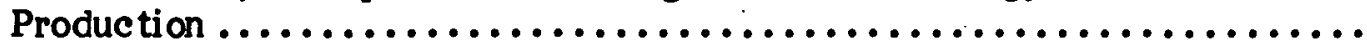

3-13 Solar Thermal, \% Capital Costs Change vs. Accumulated

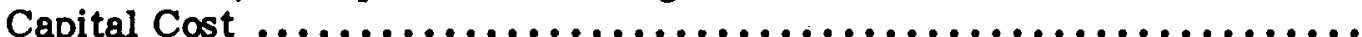

3-14 Solar Thermal, $\%$ Capital Costs Change vs. Accumulated Life-Cycle Cost ......................................

3-15 Percent Change in Solar Thermal Penetration Variables vs. \% Change in System Capital Cost for Year 2000 . . . . . . . . . . . . . . . . . . . .

3-16 Photovoltaics, \% Capital Costs Change vs. Cumulative

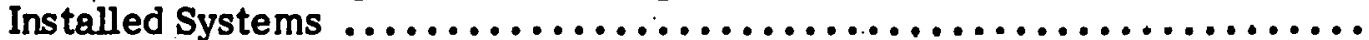

3-17 Photovoltaics, \% Capital Costs Change vs. Annual Energy Production ..........................................

3-18 Photovoltaics, \% Capital Costs Change vs. Accumulated Capital Cost .......................................

3-19 Photovoltaics, \% Capital Costs Change vs. Accumulated Lif e-Cycle Cost .....................................

3-20 Percent Change in Photovoltaic Utility Penetration Variables vs, \% Change in System Capital Cost for Year 2000 . . . . . . . . . . . . . .

3-21 Biomass, \% Capital Costs Change vs. Cumulative Installed

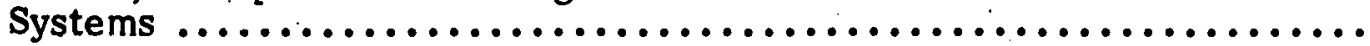

3-22 Biomass, $\%$ Capital Costs Change vs. Annual Energy Production ...........................................

3-23 Biomass, $\%$ Capital Costs Change vs. Accumulated Capital Costs............................................... 


\section{LIST OF FIGURES (continued)}

$\underline{\text { Page }}$

3-24 Biomass, \% Capital Costs Change vs. Accumulated Life-Cycle

Cost ........................................ 40

3-25 Percent Change Biomass System Penetration Variables vs. $\%$

Change in System Capital Cost for Year 2000 ...................

3-26 WECS, \% Capital Costs Change vs. Cumulative Installed

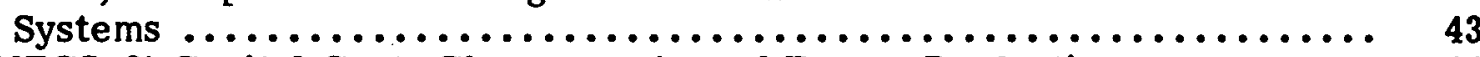

3-27 WECS, \% Capital Costs Change vs. Annual Energy Production . . . . . . . . 44

3-28 WECS, \% Capital Costs Change vs. Annual Fuel

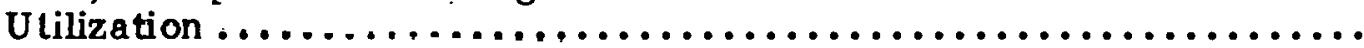

3-29 WF.CS, \% Capital Costs Change vs. Accumulated Capltal

Costs.............................................

3-30 WECS, \% Capital Custs Changc vs. Acelımuląted Life-Cycle

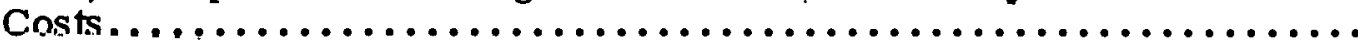

3-31 Percent Change in WECS Syetem Penetration Variables vs. \%

Change in System Capital Cost for Year 2000 ...................

3-32 OTEC, \% System Capital Costs Change vs. Cumulative

Installed System ....................................

3-33 OTEC, \% System Capital Costs Change vs. Annual Energy

Production ..................................... 50

3-34 OTEC, \% System Capital Costs Change vs. Accumulated Capital

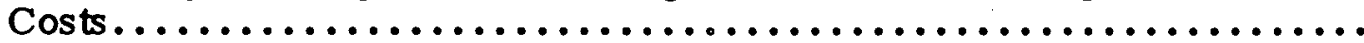

3-35 OTEC, \% System Capital Costs Change vs. Accumulated

Life-Cycle Costs.....................................

3-36 Percent Change in OTEC System Penetration Variables vs. $\%$

Change in System Capital Cost for Year $2000 \ldots \ldots \ldots \ldots \ldots \ldots \ldots \ldots$

4-1 Process Heat, $\%$ O\&M Costs Change vs. Cumulative Installed

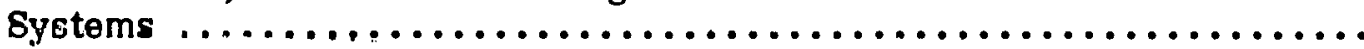

4-2 Process Heat, $\%$ O\&M Costs Change ve. Annual Energy

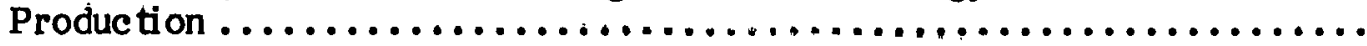

4-3 Process Heat, \% O\&M Costs Change vs. Accumulated Capital

Costs.............................................

4-4 Process Heat, \% O\&M Costs Change vs. Accumulated Life-Cycle Costs...............................................

4-5 Percent Change in Process Heat Variables vs. $\%$ Change in

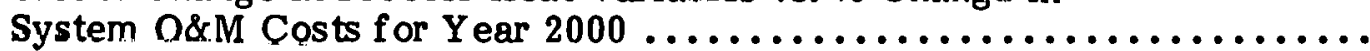

4-6 Solar Thermal, \% O\&M Costs Change vs. Cunulative Installed

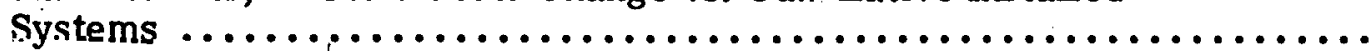

4-7 Solar Thermal, \% O\&M Costs Change vs. Annual Energy

Production ...........................................

4-8 Solar Thermal, \% O\&M Costs Change vs. Accumulated Capital

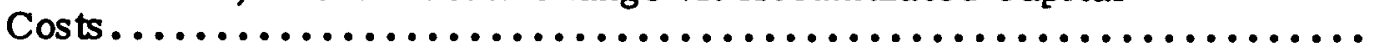

4-9 Solar Thermal, \% O\&M Costs Change vs. Accumulated Lif - Cycle Costs. . .................................

4-10 Percent Change in Solar Thermal Utility Variables vs. $\%$ Change in System Annual O\&M for Year $2000 \ldots \ldots$

4-11 Photovoltaics, \% O\&M Costs Change vs. Cumulative Installed Systems 
LIST OF FIGURES (concluded)

$\underline{\text { Page }}$

4-12 Photovoltaics, \% O\&M Costs Change vs. Annual Energy

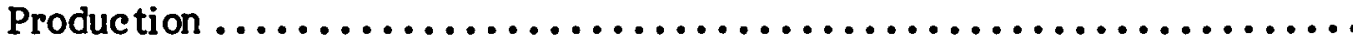

69

4-13 Photovoltaics, \% O\&M Costs Change vs. Accumulated Capital

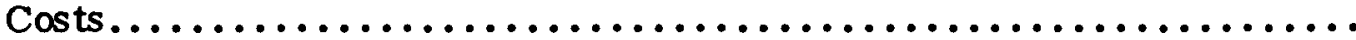

70

4-14 Photovoltaics, \% O\&M Costs Change vs. Accumulated Lif e-Cycle

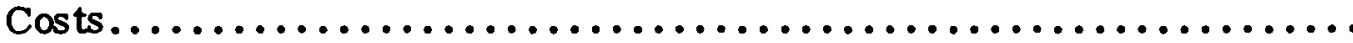

4-15 Percent Change in Photovoltaic Utility Penetration Variables

vs. \% Change in Annual O\&M Cost for Year 2000 .................

4-16 Biomass, \% O\&M Costs Change vs. Cumulative Installed Systems ........

4-17 Biomass, \% O\&M Costs Change vs. Annual Energy Production ...........

4-18 Biomass, \% O\&M Costs Change vs. Accumulated Capital Costs ...........

4-19 Biomass, \% O\&M Costs Change vs. Accumulated Lif e-Cycle Costs ........

4-20 Percent Change in Biomass System Penetration Variables vs. $\%$

Change in Annual O\&M Cost for Year 2000 ....................

77

4-21 WECS, \% O\&M Costs Change vs. Cumulative Installed Systems ..........

4-22 WECS, \% O\&M Costs Change vs. Annual Energy Production ............

4-23 WECS, \% O\&M Costs Change vs. Annual Fuel Utilization ...............

4-24 WECS, \% O\&M Costs Change vs. Accumulated Capital Costs ............

4-25 WECS, $\%$ O\&M Costs Change vs. Accumulated Life-Cycle Cost..........

4-26 Percent Change in WECS Utility Penetration Variables vs. $\%$

Change in Annual O\&M Cost for Year $2000 \ldots \ldots \ldots \ldots \ldots \ldots \ldots$

4-27 OTEC, \% Annual O\&M Costs Change vs. Cumulative Installed

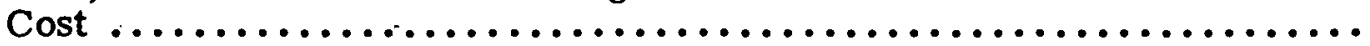

4-28 OTEC, \% Annual O\&M Costs Change vs. Annual Energy Production .......

4-29 OTEC, \% Annual O\&M Costs Change vs. Accumulated Capital Costs.............................................

4-30 OTEC, \% Annual O\&M Costs Change vs. Accumulated Life-Cycle Costs.............................................

Percent Change in OTEC Penetration Variables vs. \% Change in

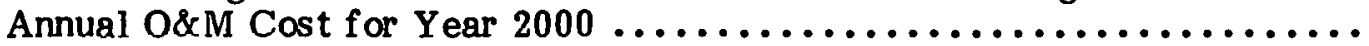

4-31 Percent Annal O\&M Cost for Year 2000

5-1 Biomass, \% Fuel Costs Change vs. Cumulative Installed Systems . . . . . . . .

5-2 Biomass, \% Fuel Costs Change vs. Annual Energy Production ............

5-3 Biomass, \% Fuel Costs Change vs. Accumulated Capital Cost ..........

5-4 Biomass, \% Fuel Costs Change vs. Accumulated Life-Cycle Cost ........

5-5 Percent Change in Biomass System Penetration Variables vs. $\%$ Change in Annual Fuel Cost for Year 2000.................... 


\section{SECTION 1.0}

\section{INTRODUCTION}

The Solar Energy Research Institute (SERI) has conducted a limited sensitivity analysis to determine the variation of projected market penetration by the model entitled A System for Projecting the Utilization of Renewable Resources (SPURR) [1]. SPURR, developed by the MITRE Corporation for the Department of Energy (DOE), is comprised of three computer programs. Each program simulates a different market sector to estimate market penetration. The computer models and the market sectors they cover are:

- SHACOB-solar heating and cooling of buildings market;*

- AIPH-agricultural and industrial process heat market [2]; and

- UTILITY-centralized electricity generation market and the synthetic fuels and produc ts market [3] .

Two scenarios have been used for analysis by the model. They contain major economic assumptions describing trends in energy demand, energy price, taxes, and incentives [2,3]. The two scenarios are:

- the Recent Trends Scenario (RTS), and

- the National Energy Plan (NEP).

The MITRE Corporation has performed a limited sensitivity analysis on the National Energy Plan (simulating the National Energy Act) scenario and Recent Trends Scenario (simulating "business-as-usual") [4]. The Domestic Policy Review (DPR) Scenario is a recent update to the NEP scenario and was developed by MITRE to investigate variations in oil prices and their effect on solar penetration. It is the DPR baseline case that was used for the sensitivity analysis done at SERI. MITRE's sensitivity analysis of the NEP and RTS scenarios has included parameters such as energy prices, tax credits and incentives, market shares, market potential, service demand growth rate, and accelerated áceeptance of solar. The sensitivity analysis performed at SERI focused on variations of solar system lifetime, solar system capital cost, and operation/maintenance cost that could be related to improvements in design and uncertainty in estimated cost.

The variations of these parameters are summarized in Table 1-1. The resul ts of the sensitivity analysis will have practical application to engineering improvements in solar technologies that can be translated to changes in the three primary variables. Secondly, the resul ts will continue the verification and validation of SPURR by contributing to the dialogue of published resul ts versus intuitive expectations and by highlighting error in the programs or algorithms.

At this point in the analysis, no significant problems were encountered other than a coding problem in the output reports of the SHACOB sector (which limited this sensitivity analysis to the AIPH and utility sectors) and unexpected resul ts when the system lifetime was varied. To facilitate the visual analysis of the sensitivity results, SERI added a

* Sensitivity of this sector was not included in this report because of problems with the program that are being corrected by MITRE. 
Table 1-1. SENSTTVITY ANALYSTS (\% VARIATIONS)

\begin{tabular}{|c|c|c|c|c|c|c|c|c|c|c|c|c|c|c|c|c|c|c|}
\hline \multirow[b]{2}{*}{$\begin{array}{l}\text { Utilities } \\
\text { Biomuss } \\
\text { OTEC } \\
\text { Photovol taies } \\
\text { Solar Thermal } \\
\text { WECS }\end{array}$} & \multirow[b]{2}{*}{ 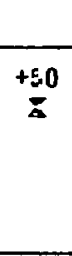 } & \multicolumn{7}{|c|}{ Capital Cast } & \multicolumn{6}{|c|}{ O\&d Costs } & \multicolumn{4}{|c|}{ Fuel Costs } \\
\hline & & $\begin{array}{c}+30 \\
\mathbf{X} \\
\mathrm{X} \\
\mathrm{X}\end{array}$ & $\begin{array}{c}+20 \\
X\end{array}$ & $\begin{array}{l}-10 \\
X \\
X \\
X \\
X\end{array}$ & $\begin{array}{l}-\mathbf{9 0} \\
\mathbf{X} \\
\mathbf{X} \\
\mathbf{X} \\
\mathbf{X} \\
\mathbf{X}\end{array}$ & $\begin{array}{c}-30 \\
X \\
X \\
X \\
X\end{array}$ & $\begin{array}{c}-40 \\
X \\
X\end{array}$ & -46 & $\begin{array}{l}+50 \\
X \\
X \\
X \\
X\end{array}$ & $\stackrel{+30}{X}$ & $\begin{array}{r}+20 \\
x \\
x \\
x\end{array}$ & $\begin{array}{c}-10 \\
X \\
X\end{array}$ & $\begin{array}{l}-20 \\
X \\
X \\
X \\
X \\
X\end{array}$ & $\begin{array}{c}-30 \\
\mathbf{X} \\
\mathbf{X} \\
\mathbf{X} \\
\mathbf{X} \\
\mathbf{X}\end{array}$ & $\stackrel{+20}{x}$ & $\stackrel{-10}{x}$ & $\underset{\mathrm{X}}{-20}$ & $\begin{array}{c}-30 \\
\mathrm{X}\end{array}$ \\
\hline $\begin{array}{l}\text { Process Heat } \\
\text { Solar Thermal }\end{array}$ & $\begin{array}{c}+30 \\
\mathbf{X}\end{array}$ & $\begin{array}{c}+40 \\
X\end{array}$ & $\begin{array}{c}+20 \\
X\end{array}$ & $\begin{array}{c}+10 \\
x\end{array}$ & $\stackrel{-10}{x}$ & $\stackrel{-20}{X}$ & $\stackrel{-40}{X}$ & $\begin{array}{c}-60 \\
X\end{array}$ & $\begin{array}{c}+50 \\
X\end{array}$ & & +2 & & $\stackrel{-20}{X}$ & $\begin{array}{c}-30 \\
X\end{array}$ & & & & \\
\hline
\end{tabular}


graphics package for plotting the required outputs. Prior to the sensitivity runs, SERI was able to replicate (on CDC computer) the baseline cases generated by MITRE to verify that there are no code or machine errors in the SERI model. The error in the model output processor of the SHACOB sector prevented SERI from performing an analysis of that sector. This will be performed at a later date when the problem is corrected. 
SEPI喽 


\section{SECTION 2.0}

\section{THE SPURR MODEL}

SPURR simulates solar technology competition in the marketplace as a tool to evaluate the future of solar energy technologies. The simulation of solar market behavior examines the effects of solar and conventional technology costs, tax incentives, subsidies, and future fuel costs on the market acceptance of solar energy al ternatives. Figure 2-1 illustrates the SPURR flow diagram. (For additional detail see Coluzzi and Rebibo, 1978; Drescher and Rebibo, 1978; MITRE, 1977; MITRE, 1978.)

\subsection{PROCESS HEAT COMPONENT}

The Agricul tural and Industrial Process Heat (AIPH) component examines the marketability of solar systems by segmenting the economic market into existing submarkets of three areas:

- nine census regions;

- six competing conventional systems (coal, gas, oil, synfuels, electric resistance, and electric heat pump); and

- temperature ranges (water at $40-60^{\circ} \mathrm{C}, 60-80^{\circ} \mathrm{C}$, and $80-100^{\circ} \mathrm{C}$; air at $50-100^{\circ} \mathrm{C}$, $100-150^{\circ} \mathrm{C}$, and $150^{\circ} \mathrm{C}$; steam at $100-150^{\circ} \mathrm{C}$ and $150^{\circ} \mathrm{C}$ ).

The annualized life-cycle solar cost is computed from a prototype-system capital cost for each application and region. The prototype capital cost is based on a generic solar design that includes storage, and it is appropriate to each temperature range. The annualized life-cycle conventional cost is computed from the fuel cost, fuel escalation rates, and capital cost. The ratio of solar cost to conventional cost is used as a figure-of-merit in the MTTRE market share function (Fig. 2-2). Some of the key assumptions for process heat are shown in Table 2-1.

\subsection{UTHLTY COMPONENT}

The centralized electric and synthetic fuels and products markets are handled by the utility module of SPURR. This market is segmented into nine census regions: five electric and four synthetic demand types.

Tables 2-2 and 2-3 list the technologies in this sector. Table 2-2 identifies the type of load that the technology will satisfy: base, intermediate, semipeaking, peaking, and fuelsaver. Those technologies that qualify as fuel savers-if the lifetime fuel savings plus capacity credit is greater than the lifetime revenue requirements of the fuel saver-are allocated to satisfy demand for that year. The remaining demand for electricity and synthetic fuels is allocated among solar and conventional technologies using a probabilityof-least-cost approach, a Monte Carlo simulation. In this allocation, the technology's annualized cost, present value over the lifetime of the plant, is used and constrained by building rate and rate of penetration. Experience factors are then applied to appropriate technologies at the end of the year for computing market penetration for the following year. Some of the key assumptions for utility and synthetic products are shown in Table 2-4. 


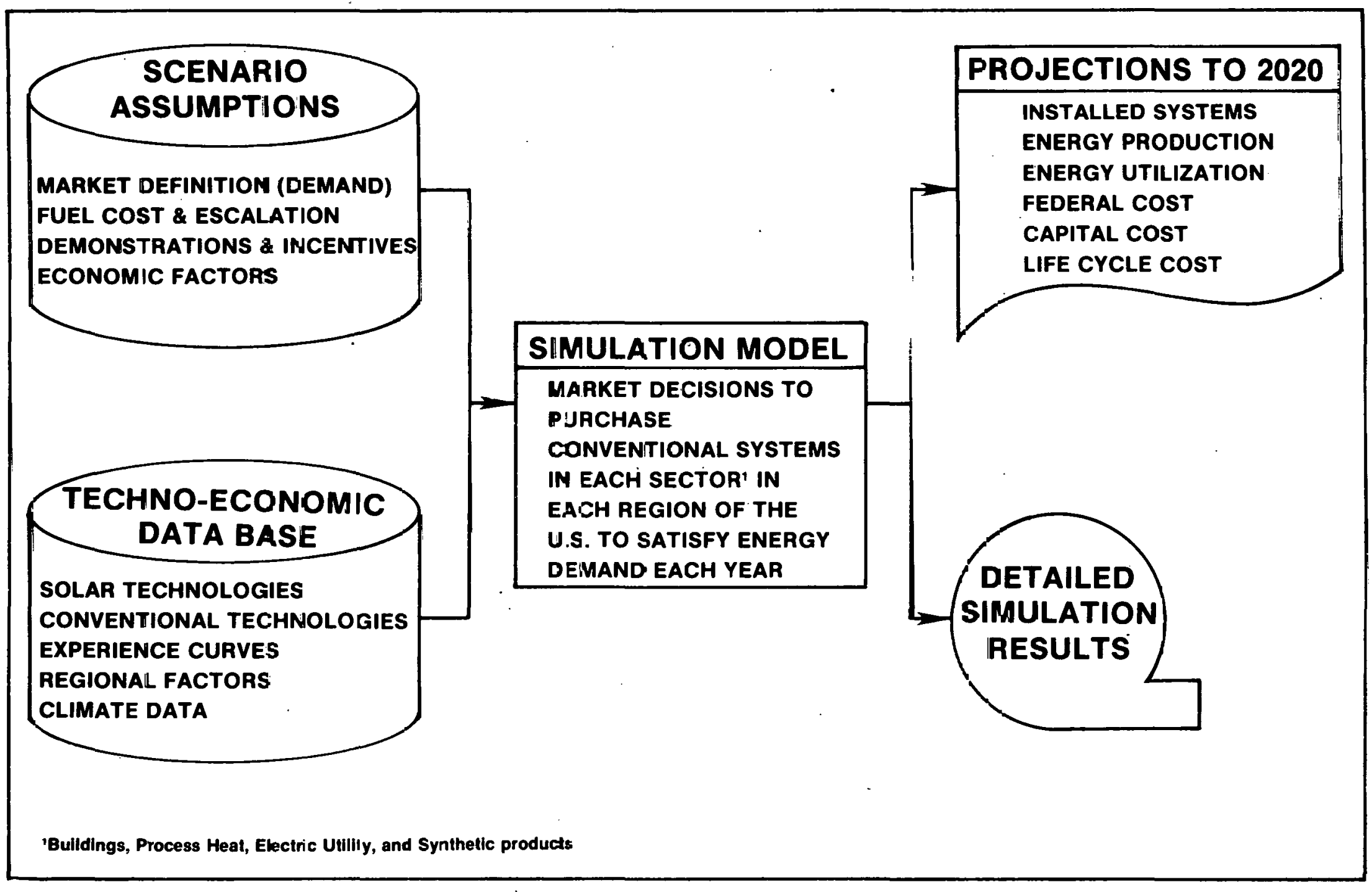

Figure 2-1. SPURR Flow Diagram 


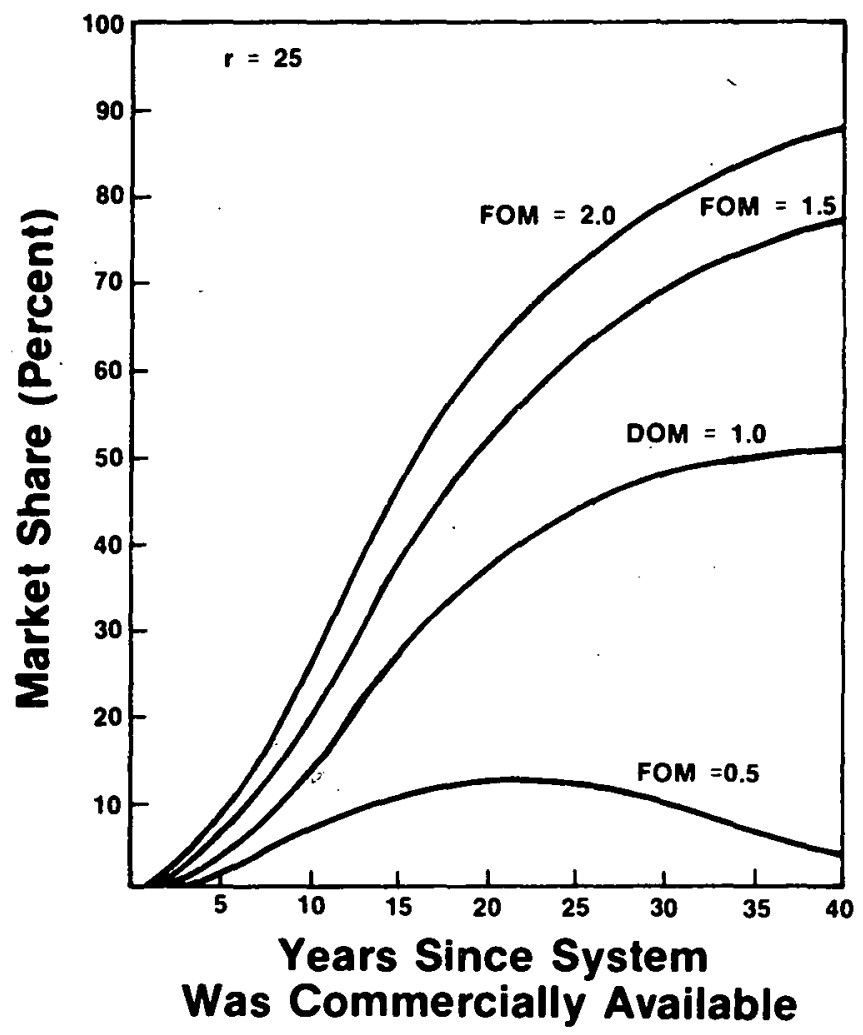

The METREK market share function is represented by the following equation:

$$
\begin{aligned}
& Y=\frac{1}{1+1 /\left[F \tanh (\hat{T}) e^{(1-1 / F)} \hat{T}_{j}\right]} \\
& \text { where } T=\left(\frac{T-T_{n}}{r}\right)^{2}
\end{aligned}
$$

- $\mathbf{Y}=$ solar share

$F=$ figure of merit

$\mathbf{T}=$ time

$\mathbf{T}_{0}=$ year in which technology first became generally available

$r$ = time scale factor representing number of years requilired for the technology to mature

In this anlaysis, $T_{0}$ Is assumed to be 1973, and $r$ is assumed to be 25 years.

Figure 2-2. MITRE Market Share Function 
Table 2-1. PROCESS HEAT BASEINTE ASSUMPTIONS IN SPURR

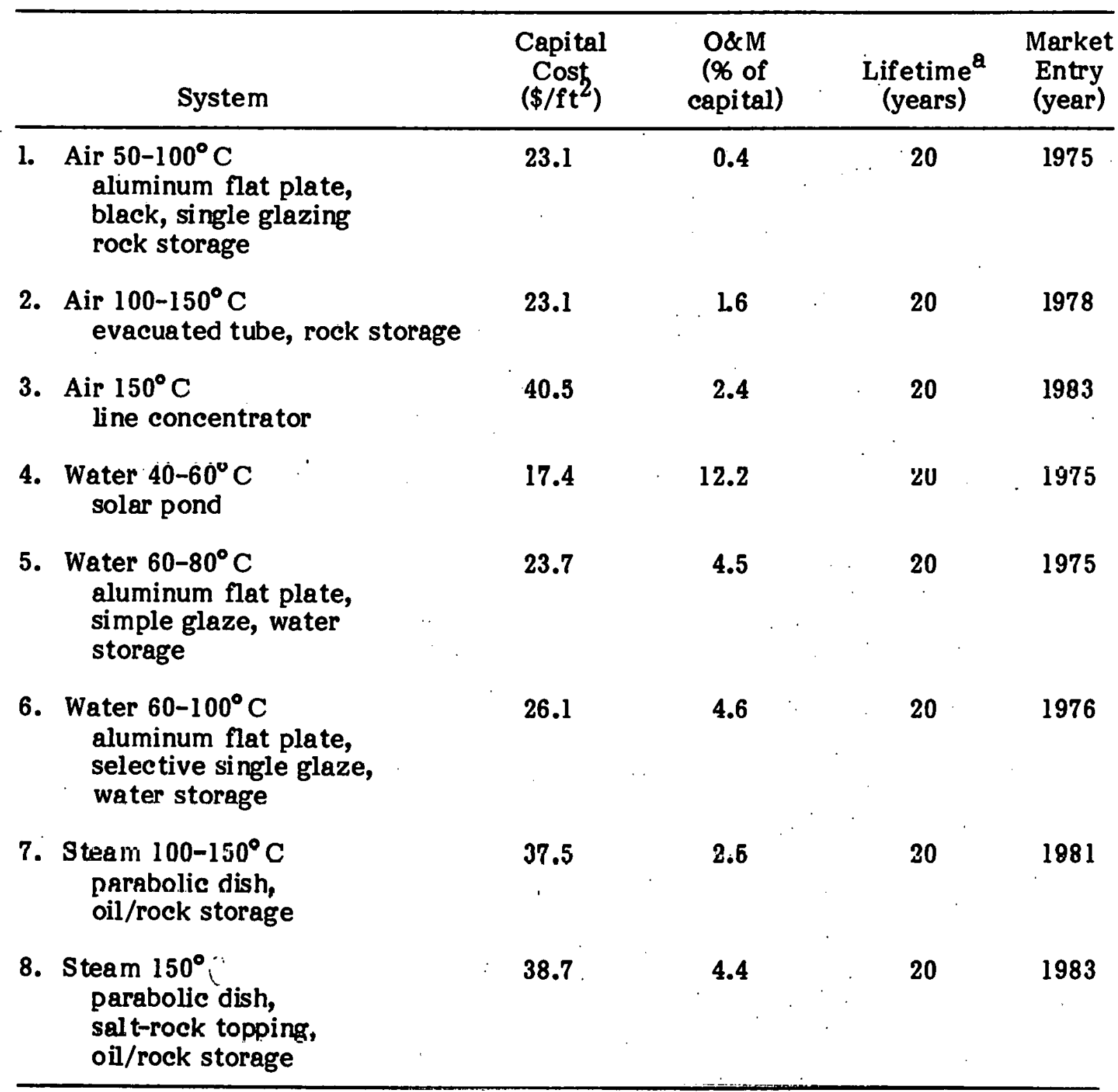

$a_{\text {All must have the same lifetime. }}$ 
Table 2-2. ELECTRIC TECHNOLOGIES

\begin{tabular}{|c|c|c|c|}
\hline $\begin{array}{l}\text { Type of } \\
\text { Technology }\end{array}$ & Name & Description & $\begin{array}{l}\text { System }^{\mathrm{a}} \\
\text { Type }\end{array}$ \\
\hline Biomass & $\begin{array}{l}\text { BIOLOG } \\
\text { BIOMILL } \\
\text { BIOSILP }\end{array}$ & $\begin{array}{l}\text { Wood-fired steam } \\
\text { plant/logging residues } \\
\text { Wood-fired steam plant/mill residues } \\
\text { Wood-fired steam plant/silvicul tural } \\
\text { products }\end{array}$ & $\begin{array}{c}\text { I } \\
\text { B, I } \\
B, I\end{array}$ \\
\hline Coal & $\begin{array}{l}\text { COALAFB } \\
\text { COALSTM } \\
\text { COALTS } \\
\text { COSTMPH }\end{array}$ & $\begin{array}{l}\text { Steam/atmospheric fluidized bed } \\
\text { combustion } \\
\text { Steam/flue gas desulfurization } \\
\text { Steam/thermal storage } \\
\text { Steam/pumped hydro or compressed air }\end{array}$ & $\begin{array}{l}\text { B } \\
\text { B, I } \\
\text { I, SP, P } \\
\text { SP, P }\end{array}$ \\
\hline Nuclear & $\begin{array}{l}\text { NUC-ADV } \\
\text { NUCLWR }\end{array}$ & $\begin{array}{l}\text { Nuclear heavywater reactor-CANDU type } \\
\text { Nuclear light water reactor }\end{array}$ & $\begin{array}{l}\text { B } \\
\text { B }\end{array}$ \\
\hline Oil & $\begin{array}{l}\text { OILCOCY } \\
\text { OILOCGT }\end{array}$ & $\begin{array}{l}\text { Combined cycle oil plant } \\
\text { Open cycle gas turbine }\end{array}$ & $\begin{array}{l}\mathrm{I}, \mathbf{S P} \\
\mathbf{P}\end{array}$ \\
\hline OTEC & OTEC & Ocean thermal energy conversion. & B \\
\hline Photovol taic & $\begin{array}{l}\text { PHOFLM } \\
\text { PHOSIL } \\
\text { PHOSILFS }\end{array}$ & $\begin{array}{l}\text { Collector/reflector system-10\% } \\
\text { efficient } \\
\text { Thin film cells } \\
\text { Collector/reflector system-16\% } \\
\text { efficient, silicon cells } \\
\text { Fuel-saver silicon cells }\end{array}$ & $\begin{array}{l}\text { I, SP } \\
\text { FS } \\
\text { I, SP } \\
\text { FS }\end{array}$ \\
\hline Solar Thermal & $\begin{array}{l}\text { SOTHCRCC } \\
\text { SOTHCRFS } \\
\text { SOTHCRTS } \\
\text { SOTHREP } \\
\text { SOTHCRST }\end{array}$ & $\begin{array}{l}\text { Central receiver/combined cycle hybrid } \\
\text { Central receiver fuel saver } \\
\text { Central receiver/thermal storage } \\
\text { Central receiver repowering } \\
\text { Central receiver/thermal storage }\end{array}$ & $\begin{array}{l}\text { I } \\
\text { FS } \\
\text { I, SP } \\
\text { I }\end{array}$ \\
\hline $\begin{array}{l}\text { Wind Energy } \\
\text { Conversion } \\
\text { Systems } \\
\text { (WECS) }\end{array}$ & $\begin{array}{l}\text { WECS2CC } \\
\text { WECS2FS } \\
\text { WECS2GT } \\
\text { WECS2WS } \\
\text { WECSIGT } \\
\text { SECSIFS }\end{array}$ & $\begin{array}{l}\text { Advanced design/comblned cycle hybrid } \\
\text { Fuel saver } \\
\text { Gas turbine hybrid } \\
\text { Water saver with pumped hydro } \\
\text { MODI gas turbine } \\
\text { MODI fuel saver }\end{array}$ & $\begin{array}{l}\text { B } \\
\text { FS } \\
\text { I } \\
\text { I } \\
\text { I } \\
P \text { FS }\end{array}$ \\
\hline
\end{tabular}

${ }_{\text {B }}$-Base, I-Intermediate, SP-Semipeak, P-Peak, FS-Fuel Saver.

A fuel saver is a system without back-up or storage. 
Table 2-3. SYNTHETIC FURIS AND PRODUCTS TECHNOLOGY

Type of

Technology

Name

Description

Ammonia

Gas

Methanol

Synthetic

Crude

Oil

Synthetic
Natural
Gas

GSDMDRED

AMHSCG

AMMLGRS

AMMSIL

AMMOTEC

AMHSCO

MEHSCO

METLGRS

METMLRS

METSIL

SNCDCO

SNCDSIL

SNCISSH

SNCLGRS

SNCMLRES

SNCRETSH

SNGCRRES

SNGHSCO

SNGLGRS

SNGMLRES

SNGSIL
Production from high sulfur coal

Production from logging residues

Production from silvicul tural products

Production from OTEC

Production from coal

Gas Demand Reduction: a dummy technology producing gas at the price of natural gas and competing in the synthetic natural gas market

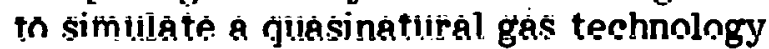

Production from high sulfur coal

Production from logging residues

Production from mill residues

Production from silvicul tural products

Production from high sulfur coal Production from silvicultural products

Production from in situ shale oil

Production from logging residues

Production from mill residues

Production from mill shale oil

Production from crop residues

Production from high sulfur coal

Production fronl logying residues

Production from mill residues

Production from silvicultural produc ts 
Table 2-4. UTIITY AND SYNTHETIC PRODUCTS BASELINE ASSUMPTIONS IN SPURR AND GROUPING PER TECHNOLOGY CATEGORY

\begin{tabular}{|c|c|c|c|c|c|c|c|}
\hline & $\begin{array}{c}\text { Type of } \\
\text { Load Satisfied }\end{array}$ & $\begin{array}{c}\text { Capital } \\
\text { Cost } \\
(\$ / \mathrm{kW})\end{array}$ & & $\begin{array}{c}\text { O\& M } \\
\text { Cost } \\
(\$ / \mathrm{kW})\end{array}$ & $\begin{array}{l}\text { Lifetime } \\
\text { (years) }\end{array}$ & $\begin{array}{l}\text { Size } \\
(\mathrm{MW})\end{array}$ & $\begin{array}{l}\text { Market } \\
\text { Entry }\end{array}$ \\
\hline \multicolumn{8}{|l|}{ A. Photovol taics } \\
\hline 1. PHOSI & Inter. & $\$ 4,081$ & $\$$ & 64.0 & 30 & $\begin{array}{l}100 \\
0.2\end{array}$ & $\begin{array}{l}1991 \\
1980-85\end{array}$ \\
\hline 2. PHOFLM & Inter. & 49,016 & & 82.0 & 30 & $\begin{array}{l}100 \\
1.0\end{array}$ & $\begin{array}{l}1991 \\
1981-86\end{array}$ \\
\hline 3. PHOCON & Inter. & 8,200 & & 23.5 & 30 & $\begin{array}{c}5.0 \\
100 \\
1.0\end{array}$ & $\begin{array}{l}2030 \\
2030 \\
2030\end{array}$ \\
\hline 4. PHOFLR! & Semi PK & $\$ 30,686$ & $\$$ & 39.0 & 30 & $\begin{array}{r}10 \\
100\end{array}$ & $\begin{array}{l}1985 \\
1991\end{array}$ \\
\hline 5. PHOSI & Semi PK & 25,551 & & 29.0 & 30 & $\begin{array}{r}10 \\
100\end{array}$ & $\begin{array}{l}1976-91 \\
1991\end{array}$ \\
\hline $\begin{array}{l}\text { 6. PHOSILFS } \\
\text { 7. PHOFLMFS }\end{array}$ & $\begin{array}{l}\text { FS } \\
\text { FS }\end{array}$ & $\begin{array}{l}19,047 \\
21,313\end{array}$ & & $\begin{array}{l}14.3 \\
19.4\end{array}$ & $\begin{array}{l}30 \\
30\end{array}$ & $\begin{array}{l}100 \\
100\end{array}$ & $\begin{array}{l}2030 \\
1991\end{array}$ \\
\hline \multicolumn{8}{|l|}{ B. Solar Thermal } \\
\hline 1. SOTHCRCC & Inter. & $\$ 1,416$ & $\$$ & 10.0 & 30 & $\begin{array}{l}100 \\
100\end{array}$ & $\begin{array}{l}2030 \\
1989\end{array}$ \\
\hline $\begin{array}{l}\text { 2. SOTHCRTS } \\
\text { 3. SOTHCRST } \\
\text { 4. SOTHREP } \\
\text { 5. SOTH CRFS }\end{array}$ & $\begin{array}{l}\text { Inter. } \\
\text { Semi PK } \\
\text { Inter. } \\
\text { FS }\end{array}$ & $\begin{array}{l}4,130 \\
2,687 \\
2,157 \\
2,328\end{array}$ & & $\begin{array}{r}20.0 \\
14.0 \\
8.0 \\
12.0\end{array}$ & $\begin{array}{l}30 \\
30 \\
30 \\
30\end{array}$ & $\begin{array}{r}5 \\
100 \\
50 \\
100\end{array}$ & $\begin{array}{l}1980-85 \\
1991 \\
1986 \\
1991\end{array}$ \\
\hline \multicolumn{8}{|l|}{ C. WECS } \\
\hline $\begin{array}{l}\text { 1. WECS } 2 \mathrm{CC} \\
\text { 2. WECS } 1 \mathrm{GT}\end{array}$ & $\begin{array}{l}\text { Base } \\
\text { Inter. }\end{array}$ & $\begin{array}{r}\$ 1,614 \\
925\end{array}$ & $\$$ & $\begin{array}{l}28.5 \\
17.4\end{array}$ & $\begin{array}{l}30 \\
30\end{array}$ & $\begin{array}{r}100 \\
10 \\
100\end{array}$ & $\begin{array}{l}1989 \\
2030 \\
1989\end{array}$ \\
\hline $\begin{array}{l}\text { 3. WECS } 2 \text { GT } \\
\text { 4. WECS } 2 \text { WS } \\
\text { 5. WECS } 1 \text { FS } \\
\text { 6. WECS } 2 \text { FS }\end{array}$ & $\begin{array}{l}\text { Inter. } \\
\text { Inter. } \\
\text { FS } \\
\text { FS }\end{array}$ & $\begin{array}{r}1,495 \\
1,670 \\
805 \\
1,379\end{array}$ & & $\begin{array}{l}21.3 \\
17.0 \\
21.9 \\
27.8\end{array}$ & $\begin{array}{l}30 \\
30 \\
30 \\
30\end{array}$ & $\begin{array}{l}1.5 \\
100 \\
100 \\
100\end{array}$ & $\begin{array}{l}1980-85 \\
1986 \\
2030 \\
1989\end{array}$ \\
\hline \multicolumn{8}{|l|}{ D. Biomass } \\
\hline $\begin{array}{l}\text { 1. BIOMLL } \\
\text { 2. BIOSLP } \\
\text { 3. BIOSILP } \\
\text { 4. BIOMILL } \\
\text { 5. BIOLOG } \\
\text { 6. METSIL } \\
\text { 7. METLGRS } \\
\text { 8. METMLRS } \\
\text { 9. SYNMLRES } \\
\text { 10. SNCDSL } \\
\text { 11. SNCLGRS } \\
\text { 12. AMMSIL } \\
\text { 13. AMMLGRS } \\
\text { 14. SNGSIL } \\
\text { 15. SNGLGRS } \\
\text { 16. SNGRRES } \\
\text { 17. SNGMLRES }\end{array}$ & $\begin{array}{l}\text { Base } \\
\text { Base } \\
\text { Inter. } \\
\text { Inter. } \\
\text { Inter. } \\
\text { Methanol } \\
\text { Methanol } \\
\text { Mothanol } \\
\text { Syncrude } \\
\text { Syncrude } \\
\text { Syncrude } \\
\text { Ammonia } \\
\text { Ammonia } \\
\text { SNG } \\
\text { SNG } \\
\text { SNG } \\
\text { SNG }\end{array}$ & $\begin{array}{r}\$ 1,190 \\
1,190 \\
1,190 \\
1,190 \\
1,190 \\
13.4 \\
13.4 \\
13.4 \\
3.7 \\
3.7 \\
3.7 \\
173.0 \\
173.0 \\
5.4 \\
5.4 \\
9.1 \\
5.4\end{array}$ & $\$$ & $\begin{array}{l}78.0 \\
78.0 \\
48.7 \\
48.7 \\
48.7 \\
2.03^{8} \\
2.03 \\
2.03 \\
0.73 \\
0.73 \\
0.73 \\
28.0 \\
28.0 \\
1.18 \\
1.18 \\
2.07 \\
1.18\end{array}$ & $\begin{array}{l}30 \\
30 \\
30 \\
30 \\
30 \\
30 \\
30 \\
30 \\
25 \\
30 \\
30 \\
30 \\
30 \\
30 \\
30 \\
30 \\
30\end{array}$ & $\begin{array}{l}46 \\
46 \\
46 \\
46 \\
46 \\
0.47 \times 10^{c} \\
\\
0.64 \times 10^{c} \\
0.64 \times 10^{7} \\
0.64 \times 10^{7} \\
0.35 \times 10^{6} \\
0.35 \times 10^{6} \\
0.69 \times 10^{7} \\
0.69 \times 10^{7} \\
0.19 \times 10^{7} \\
0.69 \times 10^{7}\end{array}$ & $\begin{array}{l}1980 \\
1995 \\
1995 \\
1991 \\
1991 \\
1995 \\
1991 \\
1991 \\
1991 \\
2000 \\
1991 \\
2000 \\
1991 \\
2000 \\
1990 \\
2030 \\
1990\end{array}$ \\
\hline \multicolumn{8}{|l|}{ E. OTEC } \\
\hline $\begin{array}{l}\text { 1. OTEC } \\
\text { 2. AMNOTEC }\end{array}$ & $\begin{array}{l}\text { Base } \\
\text { Ammonia }\end{array}$ & $\begin{array}{r}\$ 2,751 \\
992^{b}\end{array}$ & $\$$ & $\begin{array}{l}35.0 \\
50.0\end{array}$ & $\begin{array}{l}30 \\
20\end{array}$ & $\begin{array}{l}400 \\
25 \\
0.62 \times 10^{6}\end{array}$ & $\begin{array}{l}1993 \\
1983-86 \\
1992\end{array}$ \\
\hline 2. AMNOTEC & - Ammonia & 992 & & 50.0 & 20 & $0.62 \times 10^{\circ}$ & 1992 \\
\hline
\end{tabular}


SEP*ㅜ

anar 
SECTION 3.0

\section{CAPITAL COST SENSITIVITY ANALYSIS}

Capital cost was varied in each SPURR sector* to evaluate the effects on the following SPURR output parameters:

- accumulated installed systems (million $\mathrm{ft}^{2}$ or $\mathrm{GW}$ ),

- annual energy production (TWh or quads/yr),

- accumulated capital cost (\$), and

- accumulated life-cycle cost (\$).

Accumulated installed systems measure the number of systems installed. Annual energy production measures the total energy production of all plants in a specific year. Accumulated capital cost is the total capital cost of all plants buil t up to a specific year and accumulated federal expense is the amount of federal money lost due to tax credits. Annual fuel utilization measures the amount of fuel burned. (Annual fuel utilized is provided for wind energy conversion systems (WECS) only to show the effect of saving fuel.) Accumulated life-cycle cost is total life-cycle cost of systems installed at that time; it includes capital cost, O\&M, and fuel cost over the lifetime of the plant. Annual fuel utilized and accumulated federal expense also were calculated as functions of variation in capital cost. Annual fuel utilized is shown for WECS only; however, the remaining data are available upon request.

The data in this section are presented in two ways: variation of penetration in real units from 1980 to 2000 as a function of time; and penetration, percentage change from baseline versus percentage change in capital cost. The technologies showing a high ratio of the percentage change in penetration versus the percentage change in capital cost were: process heat (solar thermal), solar thermal (utilities), photovol taics, and OTEC. OTEC showed extreme sensitivity on a percentage basis, but this may be due to the small number of plants that were buil t (i.e., a change of one plant when two were buil t causes a $50 \%$ change in installed systems). WECS and biomass showed the lowest sensitivity to changes in capital cost. See Tables 2-1 and 2-4 for a range of baseline capital cost in the SPURR data base and the grouping of technologics in each astegory.

In addition to displaying the data, an analysis of the results was provided in a quali tative and quantitative fashion according to three criteria: type of relationship, sense, and sensitivity. The type of relationship indicates whether the change in capital cost penetration was linear or nonlinear. Sense attempts to evaluate the direction of change in penetration with respect to intuitive feel about penetration; i.e., if capital cost increases, one feels that fewer systems should be built or vice versa. This analysis of sense is looking for obvious errors in the SPURR methodology. The final evaluation uses sensitivity in a qualitative (high, low, moderate, none) and quantitative sense (if change was linear) by reporting the proportionality of the change in penetration with the change in capital cost. Some sensitivities were as high as 10:1 (OTEC) and as low as 0.3:1 (biomass).

*A later revision of this report will include the SHACOB data. 


\subsection{PROCESS HEAT SYSTEM PENETRATION VS. CAPITAL COST VARIATION}

The sensitivity of the process heat systems up to $+60 \%$ variations in capital cost of all solar thermal technologies in this sector (see Table 2-1) as a function of time is shown in Figs. 3-1 through 3-8. Figures 3-9 and 3-10 show the percentage variations in penetration of the SPURR output parameters for the year 2000.

The changes in the process heat systems were done for all the technologies in that group simul taneously, provided that technology had entered the market (see market entry dates in Table 2-1). Individual technologies (i.e., solar ponds) can be treated separately but were not in this analysis. The following is a summary of the results:

\begin{tabular}{|c|c|c|c|c|}
\hline & $\begin{array}{c}\text { Acc.* } \\
\text { Installed } \\
\text { Systems }\end{array}$ & $\begin{array}{c}\text { Annual } \\
\text { Energy } \\
\text { Produced } \\
\end{array}$ & $\begin{array}{c}\text { Ace. } \\
\text { Cupitul } \\
\text { Cost }\end{array}$ & $\begin{array}{c}\text { Acs.. } \\
\text { LCC*4 } \\
\text { Cost }\end{array}$ \\
\hline $\begin{array}{l}\text { Type of } \\
\text { relationship }\end{array}$ & Lineur, & $\begin{array}{l}\text { Linear, } \\
\text { inverse }\end{array}$ & $\begin{array}{l}\text { Nonlinear } \\
\text { inverse }\end{array}$ & Nonlinear \\
\hline Sense & Proper & Proper & Proper & Proper $_{i}$ \\
\hline Sensitivity & High & High & $\begin{array}{l}\text { Moderate } \\
1.33: 1\end{array}$ & $\begin{array}{l}\text { Moderate } \\
1.33: 1_{1}\end{array}$ \\
\hline
\end{tabular}

The inverse linear variation effect, observed in accumulated installed systems and annual energy produced with variation in solar capital cost, is to be expected and is in the proper direction. Installed systems and annual energy production are primarily functions of market share (which, in turn, is inversely a function of solar capital cost). Thus, as capital cost decreases, the number of solar units built would increase, increasing the number of systems installed and the annual energy production.

The small variation, nonlinear effects in accumulated capital cost and accumulated lifecycle cost until year 2000 are the result of two opposing functions: (1) market share, inversely a function of solar capital cost; and (2) capital cost, a direct function of solar capital cost. Accumulated capital cost would increase due to higher market shares (when solar capital costs are reduced) but would decrease due to reduced capital cost of earh solar unit built Over the range of $-60 \%$ to $0 . \%$ variation in capital cost in process heat, the predominant factor is capital cost of individual units (thus, the curve shows a direct variation with respect to changes in capital cost), but the market share function begins to dominate when capital costs have increased to $+60 \%$ (and the penetration varies inversely) as shown in Figs. 3-9 and 3-10.

From this analysis it can be seen that any change in capital cost over the range shown reduced only the accumulated capital cost and accumulated life-cycle cost (and federal expenditure) by year 2000. This can best be seen in Figs. 3-9 and 3-10.

\footnotetext{
*Accumulated (Acc). 


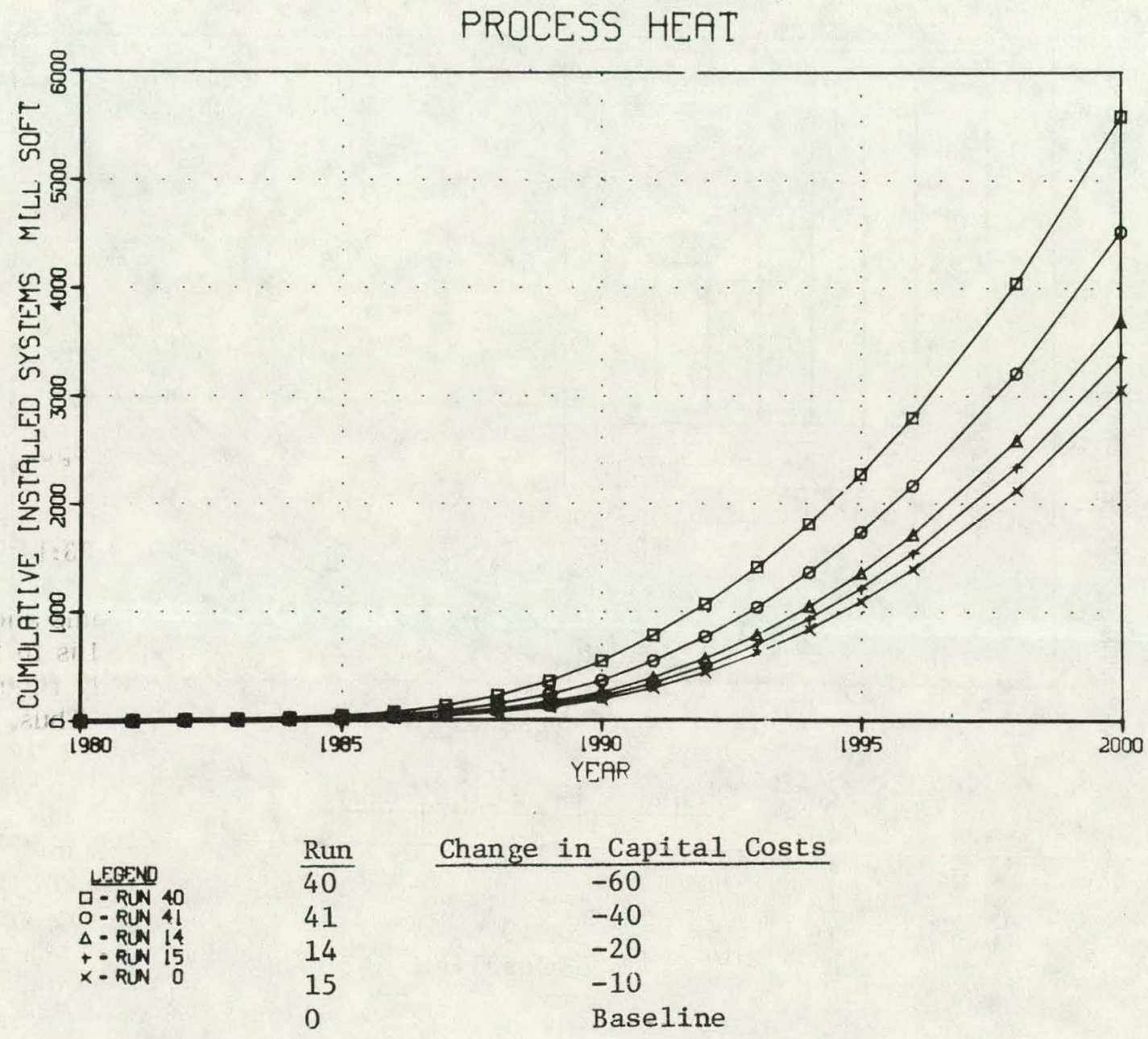

Figure 3-1. Process Heat, \% Capital Costs Change vs. Cumulative Installed System 


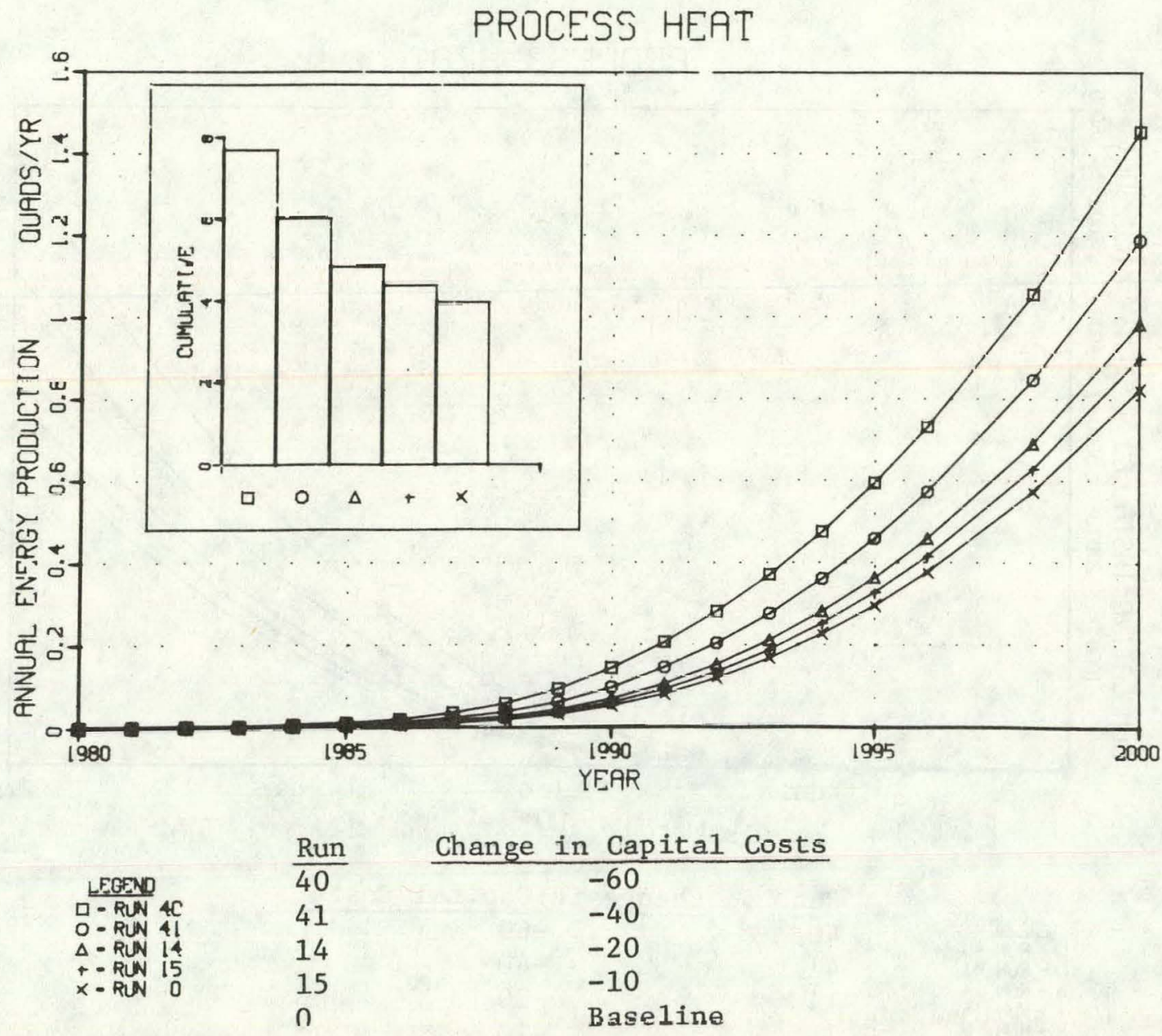

Figure 3-2. Process Heat, \% Capital Costs Change vs. Annual Energy Production 


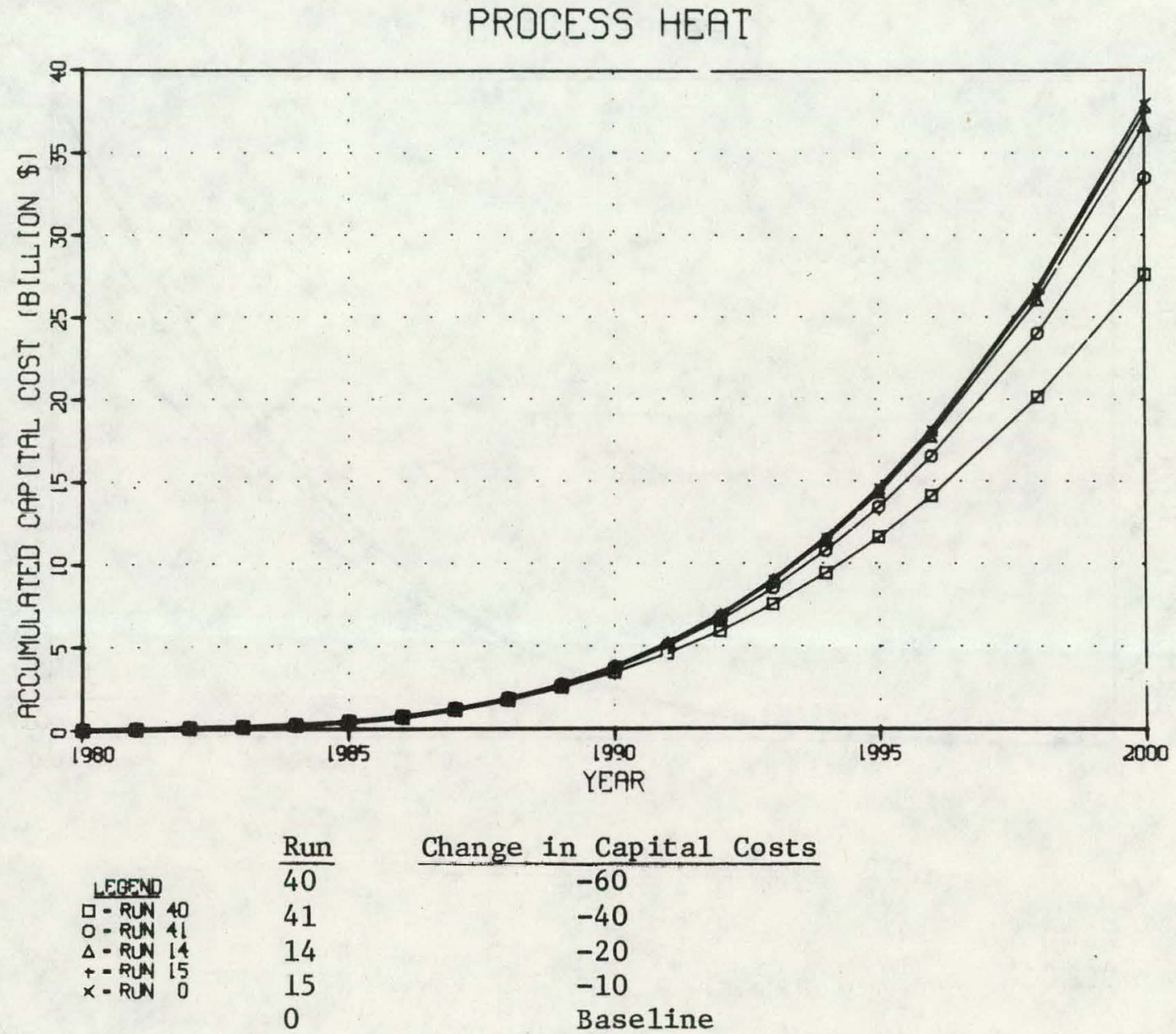

Figure 3-3. Process Heat, \% Capital Costs Change vs. Accumulated Capital Cost 
PROCESS HEAT

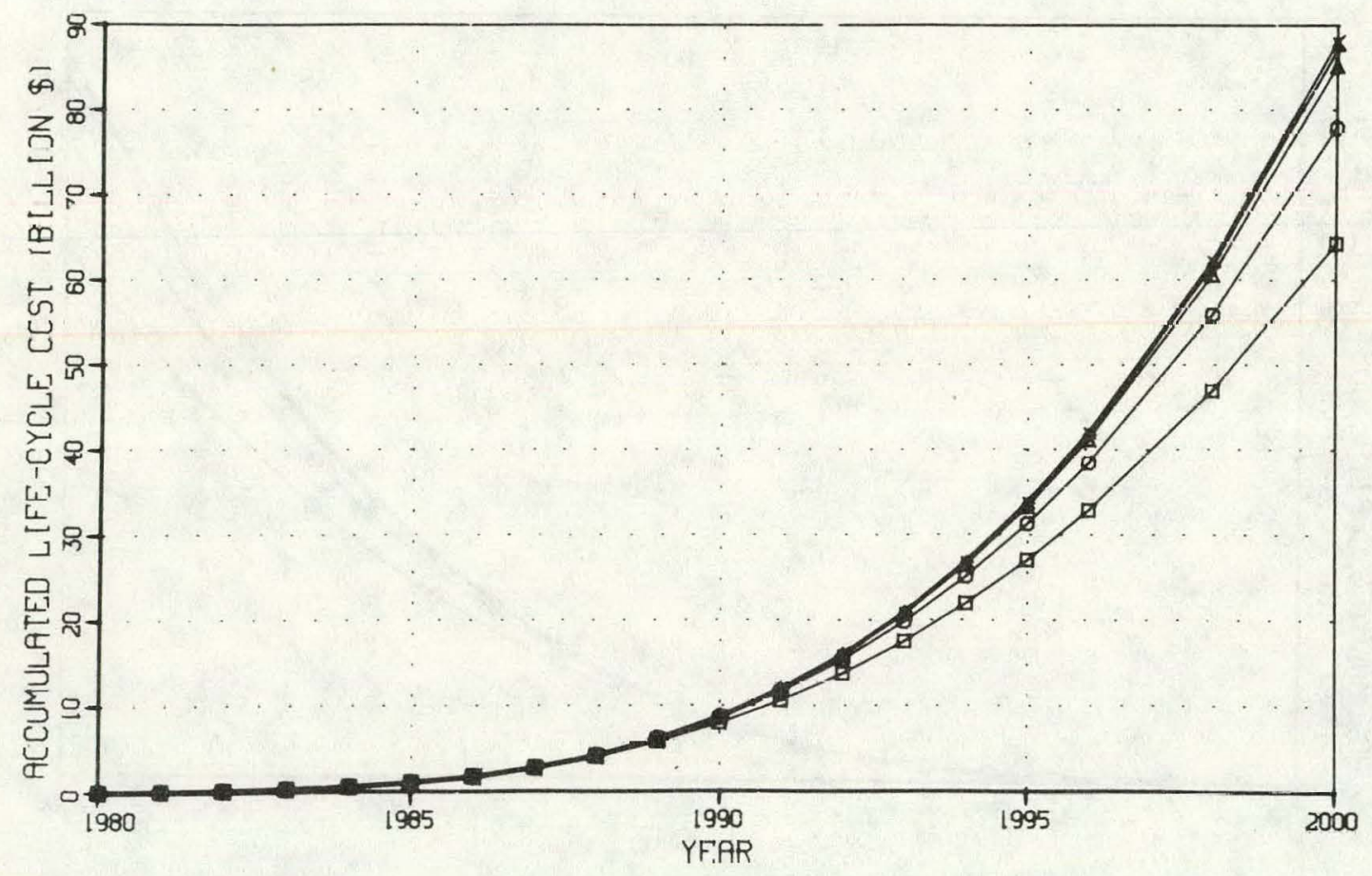

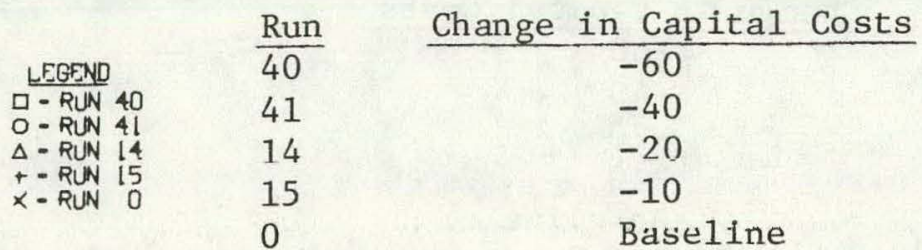

Figure 3-4. Process Heat, \% Captial Costs Change vs. Accumulated Life-Cycle Cost 


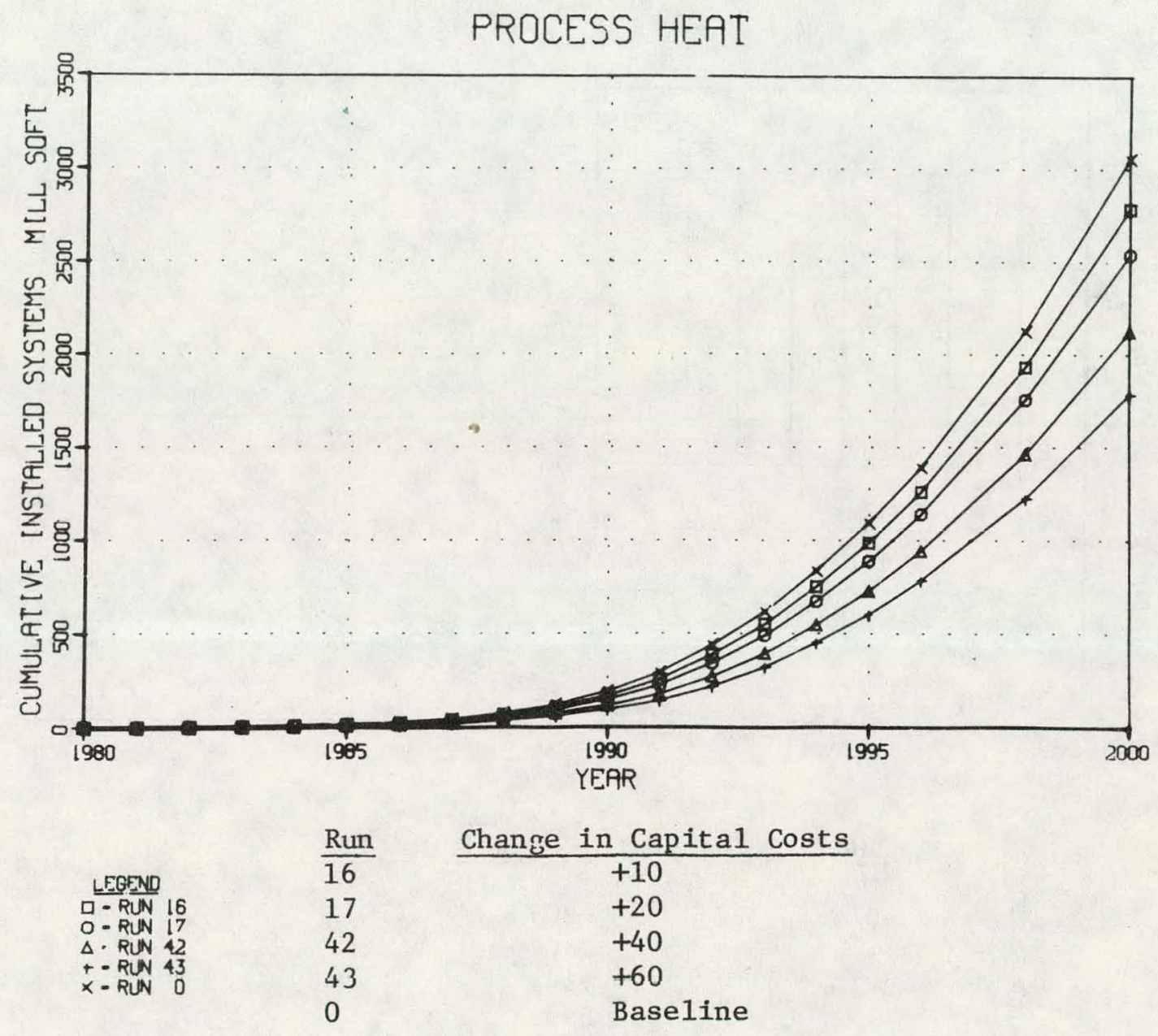

Figure 3-5. Process Heat, \% Capital Costs Change vs. Cumulative Installed Systems 


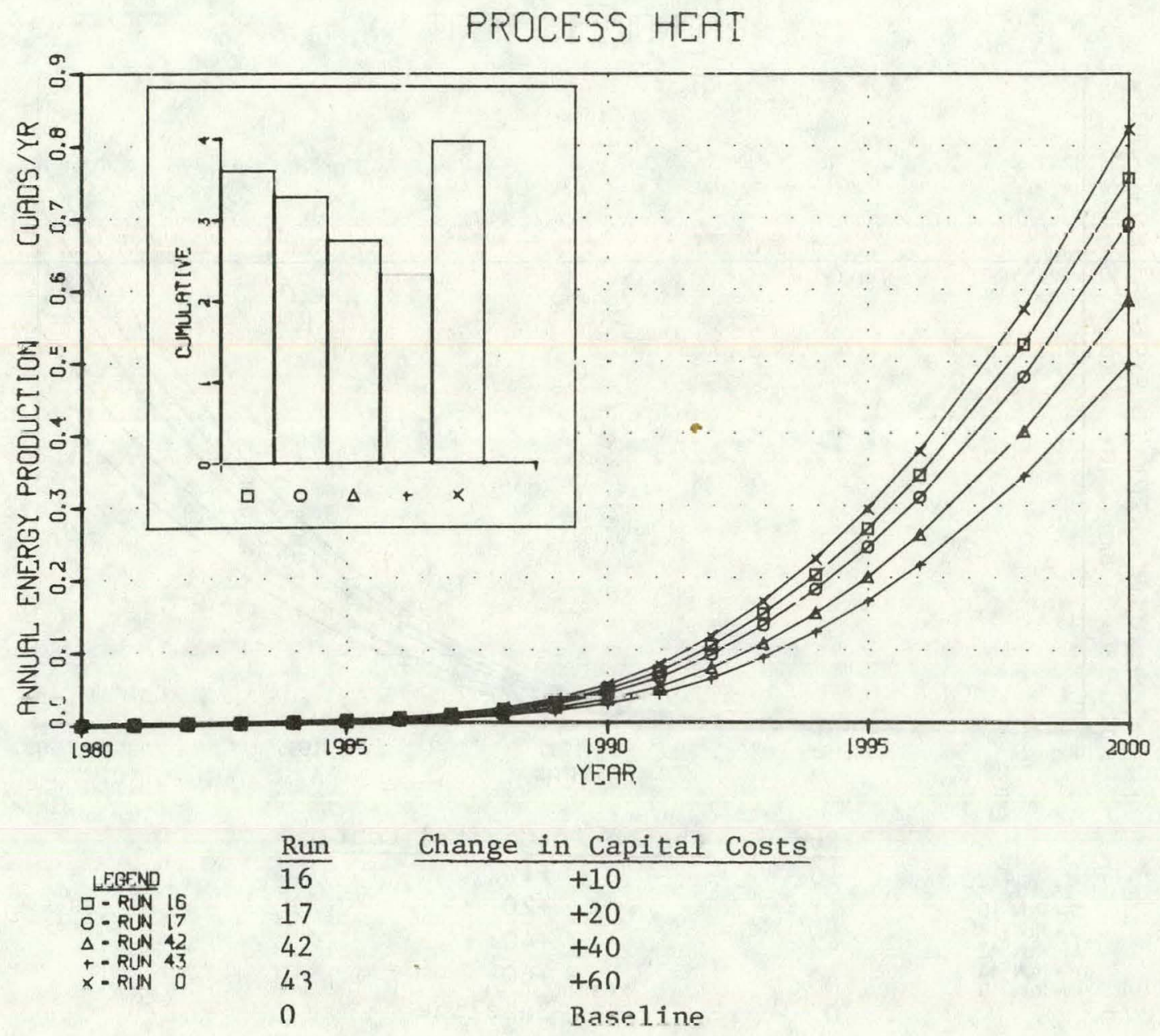

Figure 3-6. Process Heat, \% Capital Costs Change vs. Annual Energy Production 


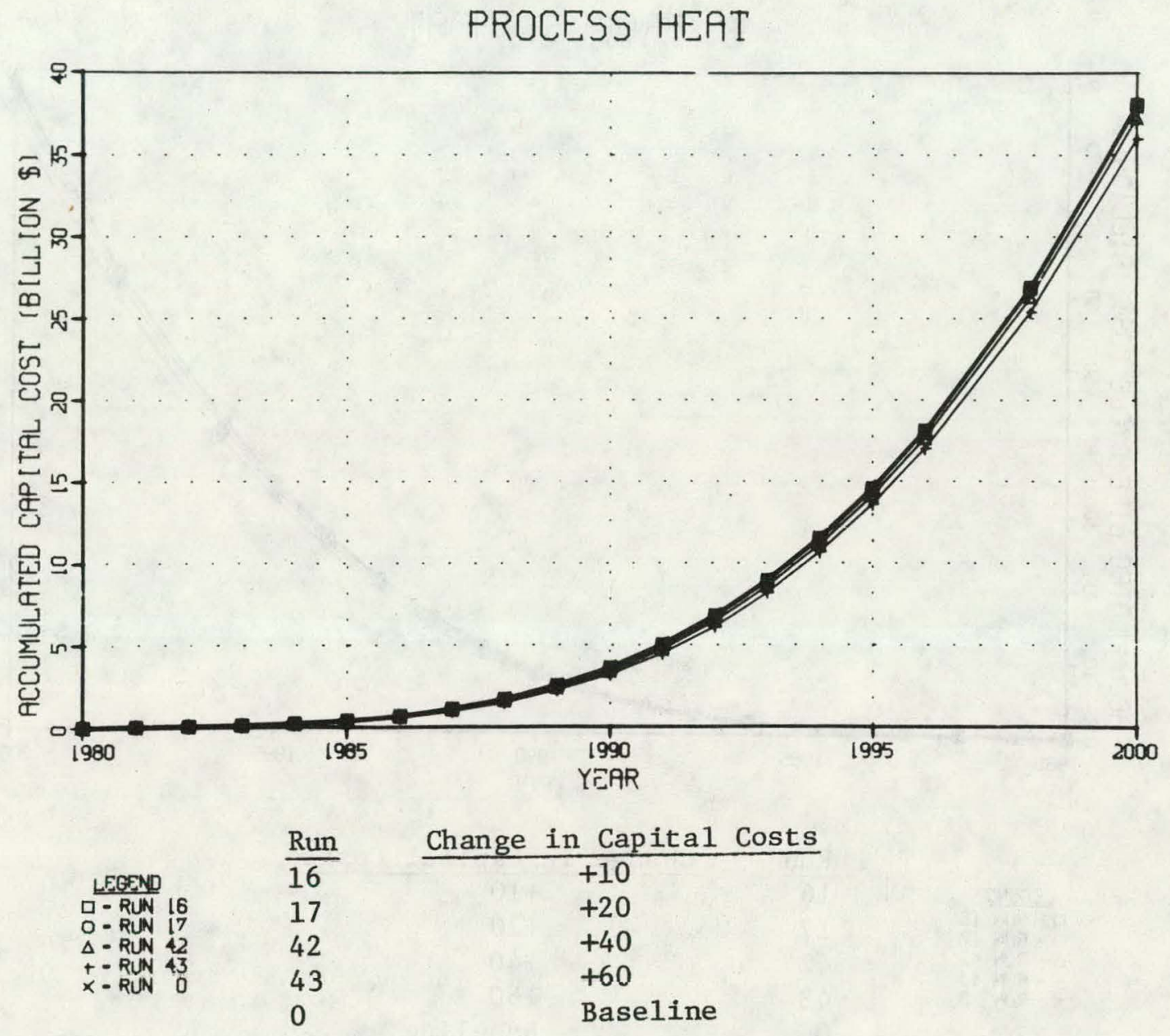

Figure 3-7. Process Heat, \% Capital Costs Change vs. Accumulative Capital Costs 
PROCESS HEAT

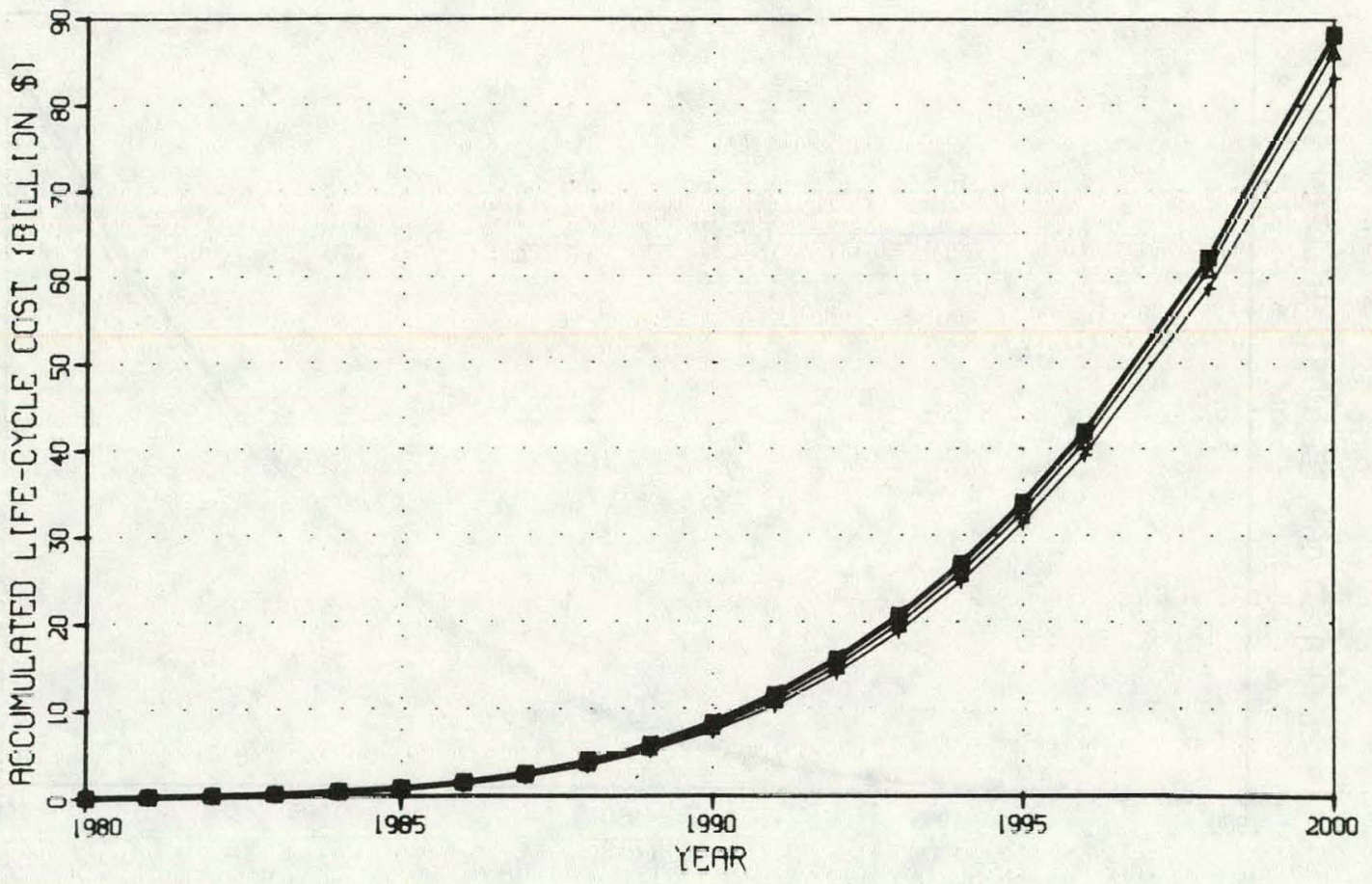

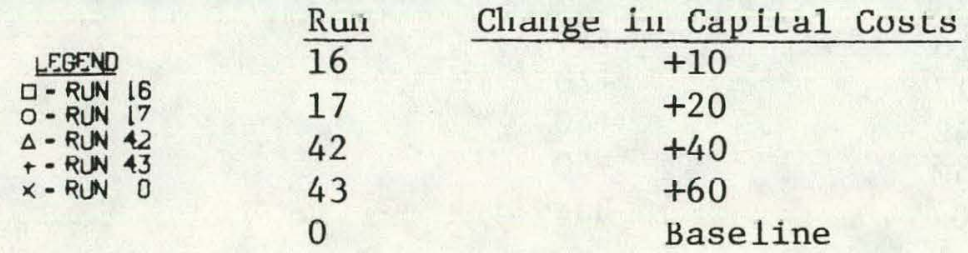

Figure 3-8. Process Heat, \% Capital Costs Change vs. Accumulated Life-Cycle Costs 


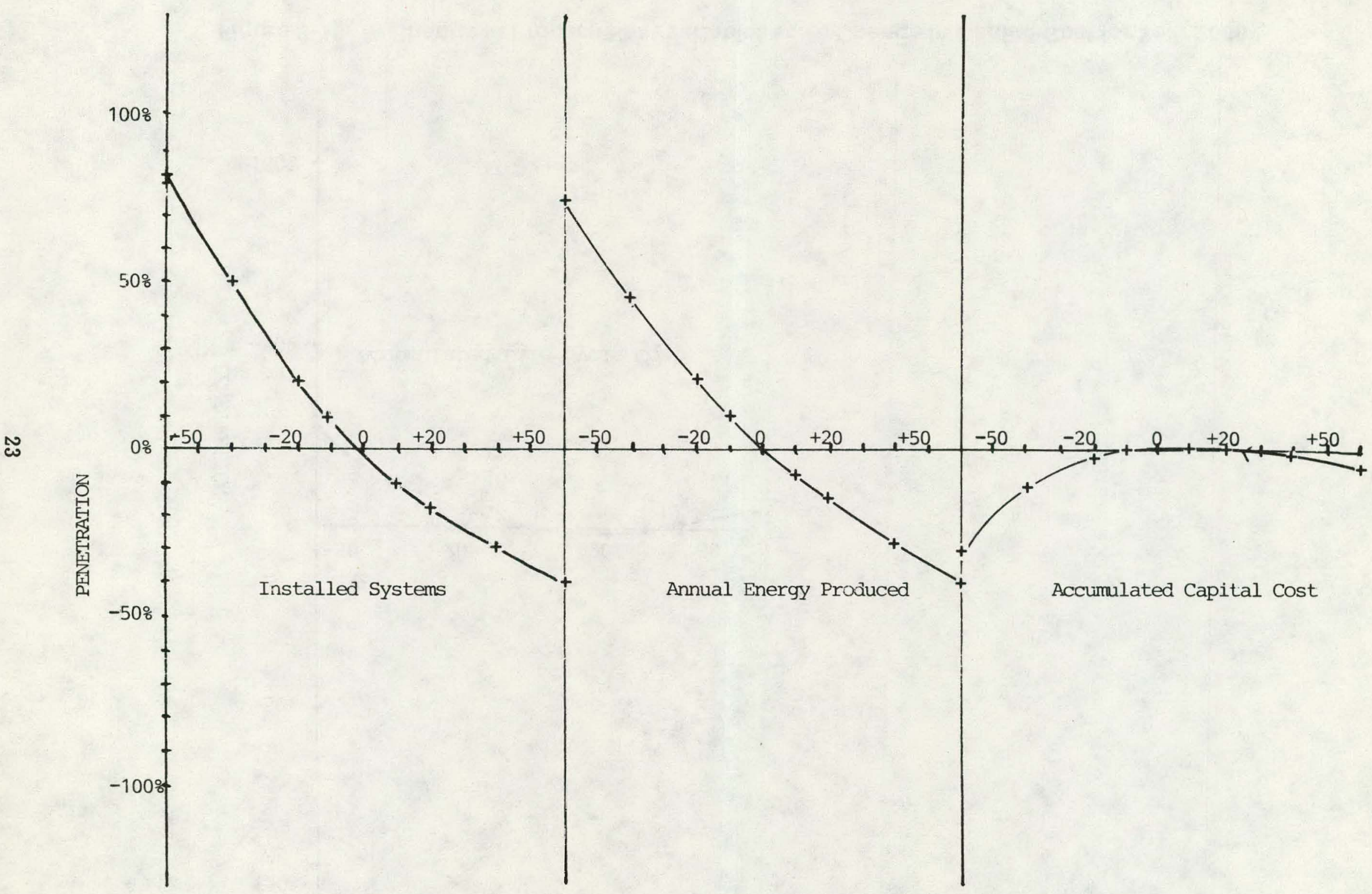

Figure 3-9. \% Change in Process Heat Variables vs. \% Change in Capital Cost for Year 2000 


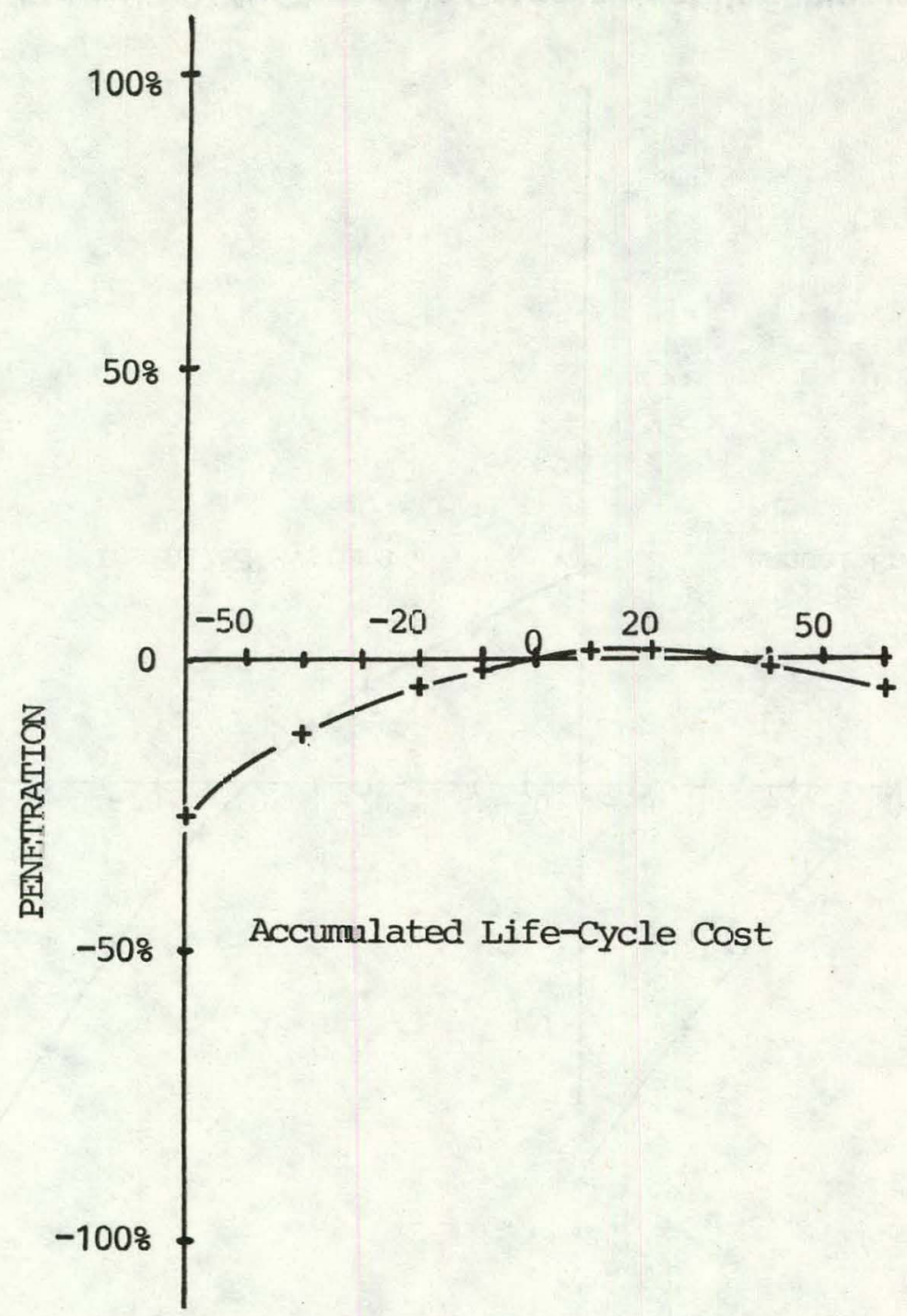

Figure 3-10. \% Change in Process Heat Variables vs. \% Change in Capital Cost for Year 2000 


\subsection{SOLAR THERMAL UTIITY PENETRATION VS. CAPITAL COST VARIATION}

The sensitivity of solar thermal utility technologies (see Table 2-4) penetration is a function of time to variations in capital cost of $-30 \%$ to $+30 \%$ as shown in Figs. $3-11$ through 3-14. Figure 3-15 shows the percentage of variation in penetration of the SPURR output parameters for year 2000. The changes in the solar thermal technologies were done as a group in this analysis but could have been done individually; i.e., the changes were the same for each technology in this group as the technology entered the market (see market entry dates in Table 2-4). The following is a summary of the results:

\begin{tabular}{|c|c|c|c|c|}
\hline & $\begin{array}{c}\text { Acc. } \\
\text { Installed } \\
\text { Systems } \\
\end{array}$ & $\begin{array}{c}\text { Annual } \\
\text { Energy } \\
\text { Produced } \\
\end{array}$ & $\begin{array}{c}\text { Acc. } \\
\text { Capital } \\
\text { Cost }\end{array}$ & $\begin{array}{l}\text { Acc. } \\
\text { LCC } \\
\text { Cost } \\
\end{array}$ \\
\hline $\begin{array}{l}\text { Type of } \\
\text { relationship }\end{array}$ & $\begin{array}{l}\text { Linear, } \\
\text { inverse }\end{array}$ & $\begin{array}{l}\text { Linear, } \\
\text { inverse }\end{array}$ & Linear & Nonlinear \\
\hline ense & Proper & Proper & Proper & Proper \\
\hline ensitivity & $\begin{array}{l}\text { High } \\
2.5: 1\end{array}$ & $\begin{array}{l}\text { High } \\
2.5: 1\end{array}$ & $\begin{array}{l}\text { Moderate } \\
1: 1\end{array}$ & $\begin{array}{l}\text { Moderate } \\
1: 1\end{array}$ \\
\hline
\end{tabular}

In viewing the change in penetration for accumulated life-cycle cost in Fig. 3-14 (see run $33,-30 \%$ change in capital cost) and in Fig. $3-15$, it is felt that the sense and nonlinearity are proper due to the inclusion of fuel-saver technologies in the group (which amounted to $45 \%$ to $50 \%$ of installed systems in year 2000). The life-cycle cost of fuel savers is negative (if they are buil t); i.e., they save more fuel than it costs to build them; while the life-cycle cost of base, intermediate, and peaking load solar thermal systems is positive. This effect is seen in those technology groups that include fuel savers (WECS, photovoltaics), but it is not seen in those that do not include fuel-saver technologies (biomass, OTEC). Additional runs using SPURR could isolate fuel savers from this group to verify this effect.

\subsection{PHOTOVOLTAICS UTHITY PENETRATION VS. CAPITAL COST}

The sensitivity of photovoltaics utility technologies (see Table 2-4) penetration as a function of time to variation of capital cost of $-40 \%$ to $+30 \%$ is shown in Figs. 3-16 through 3-19. Figure 3-20 shows the percentage variation in penetration of the SPURR output parameters for year 2000. The changes in the photovoltaics utility technologies were done as a group in this analysis but could have been done individually; i.e., the changes were the same for each technology in this group as the technology entered the marketplace (see market entry dates in Table 2-4). The following is a summary of the resul ts: 


\section{SOLAR THERMAL}

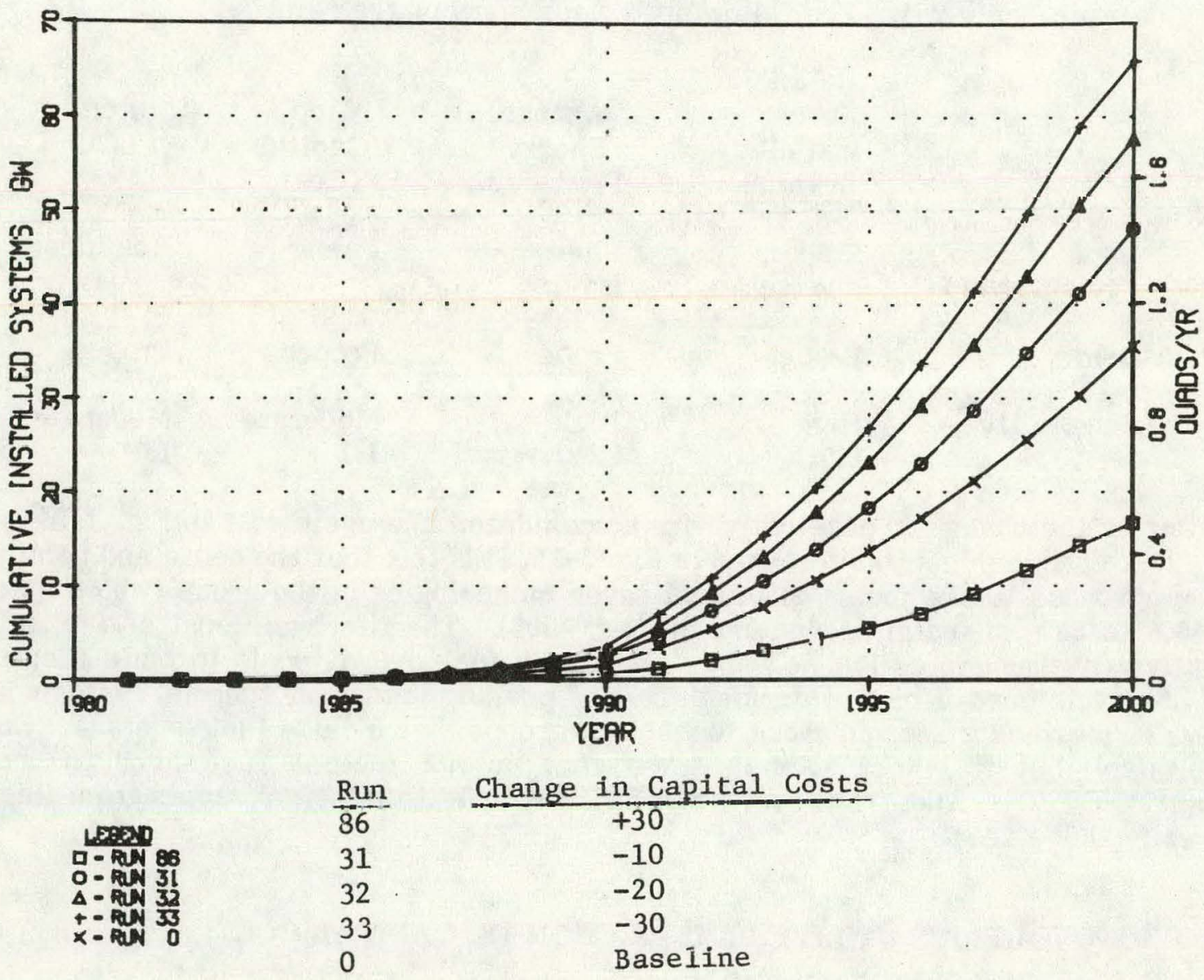

Figure 3-11. Solar Thermal, \% Capital Costs Change vs. Cumulative Installed System 


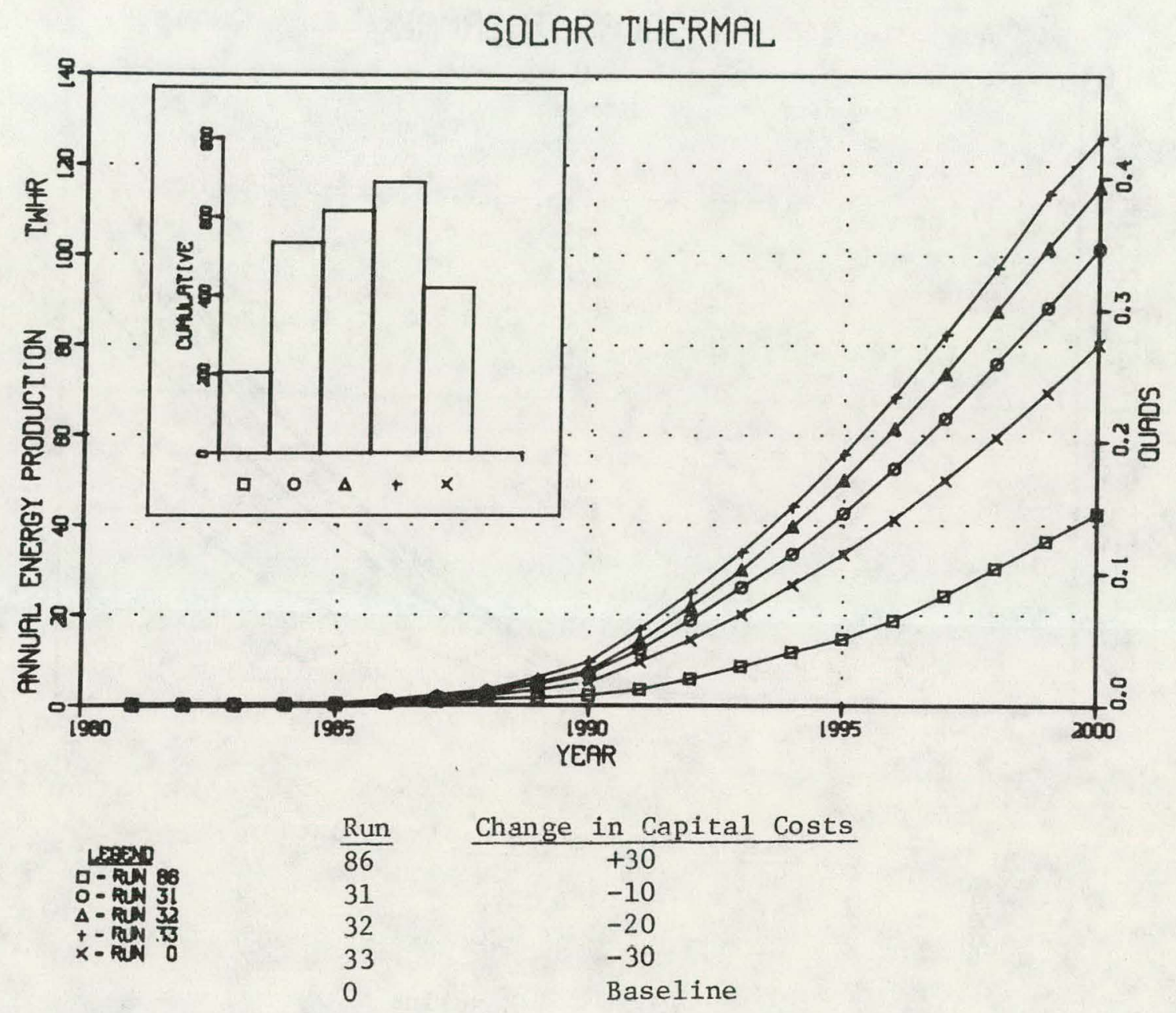

Figure 3-12. Solar Thermal, \% Capital Costs Change vs. Annual Energy Production 
SOLAR THERMAL

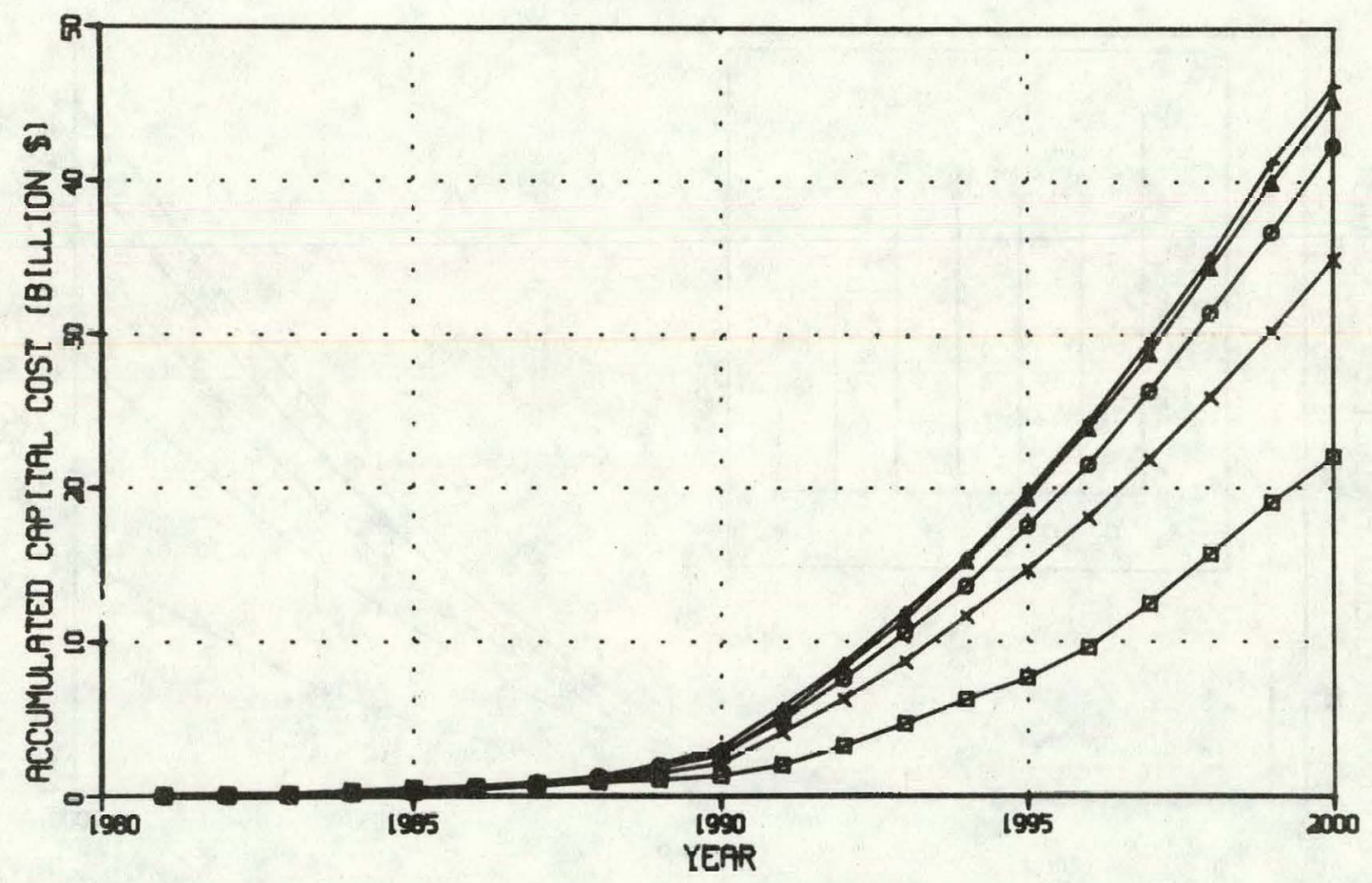

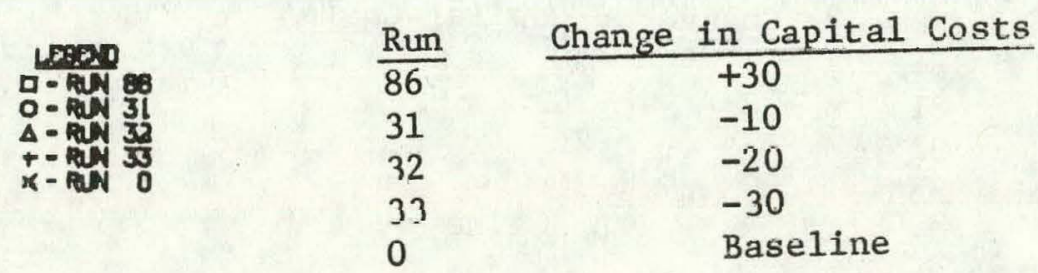

Figure 3-13. Solar Thermal, \% Capital Costs Change vs. Accumulated Capital Cost 
SOLAR THERMAL

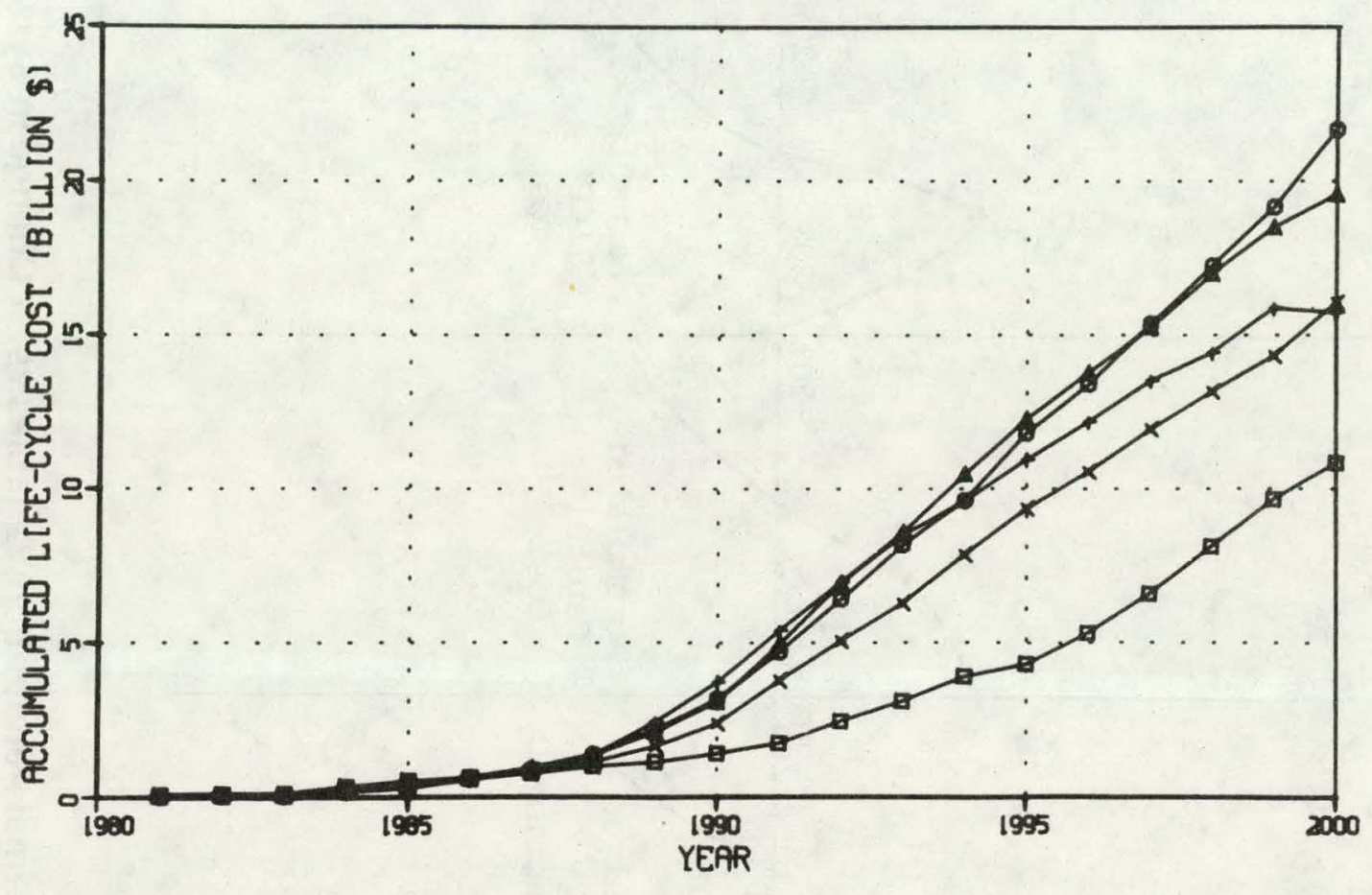

\begin{tabular}{|c|c|c|}
\hline \multirow{6}{*}{ 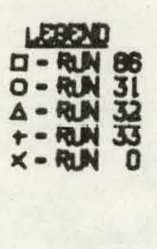 } & Run & Change in Capital \\
\hline & 86 & +30 \\
\hline & 31 & -10 \\
\hline & 32 & -20 \\
\hline & 33 & -30 \\
\hline & 0 & Baseline \\
\hline
\end{tabular}

Figure 3-14. Solar Thermal, \% Capital Costs Change vs. Accumulated Life-Cycle Cost 


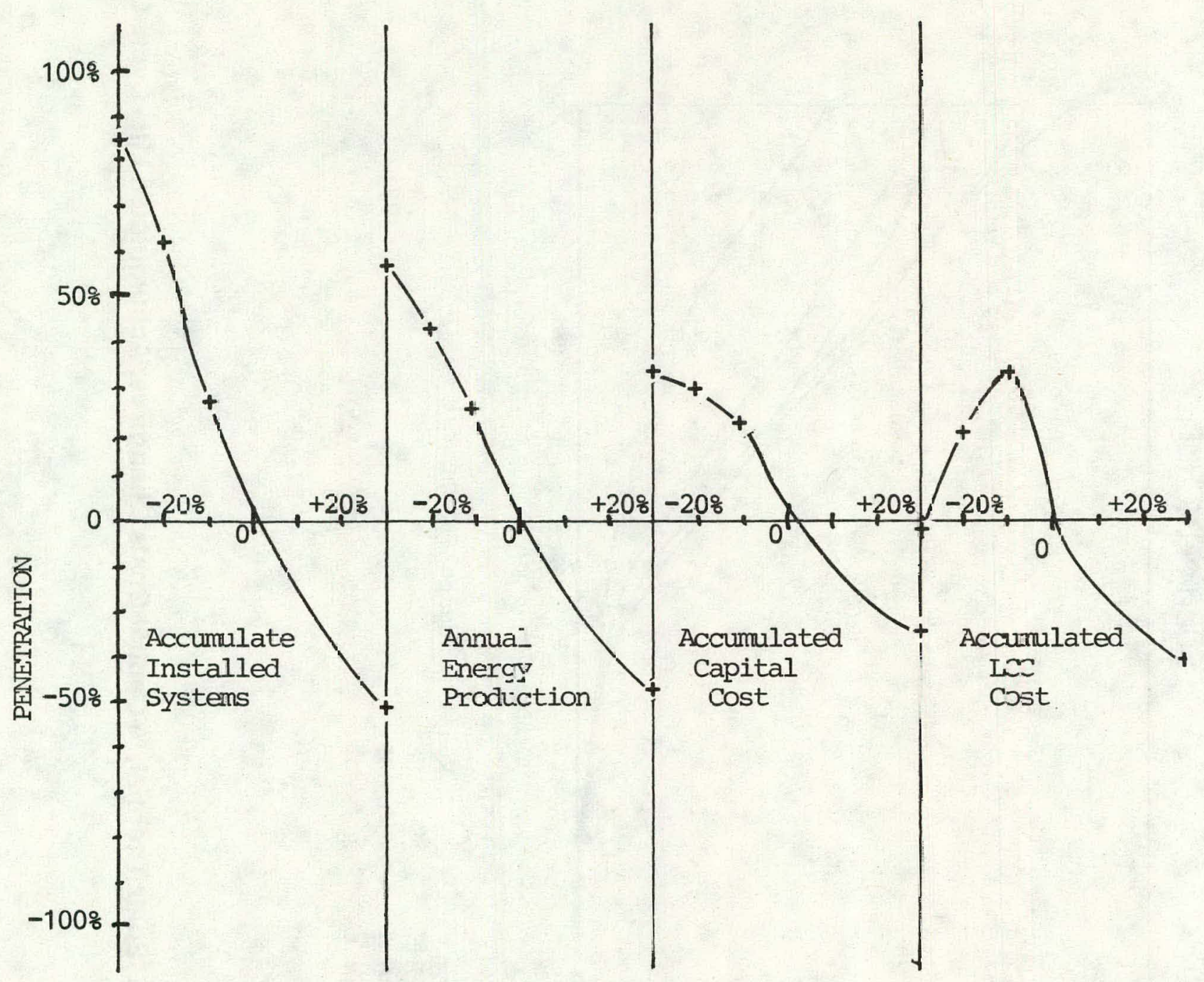

Figure 3-15. \% Change in Solar Thermal Penetration Variables vs. \% Change in System Capital. Cost for Year 2000 
PHOTOVOLTAICS

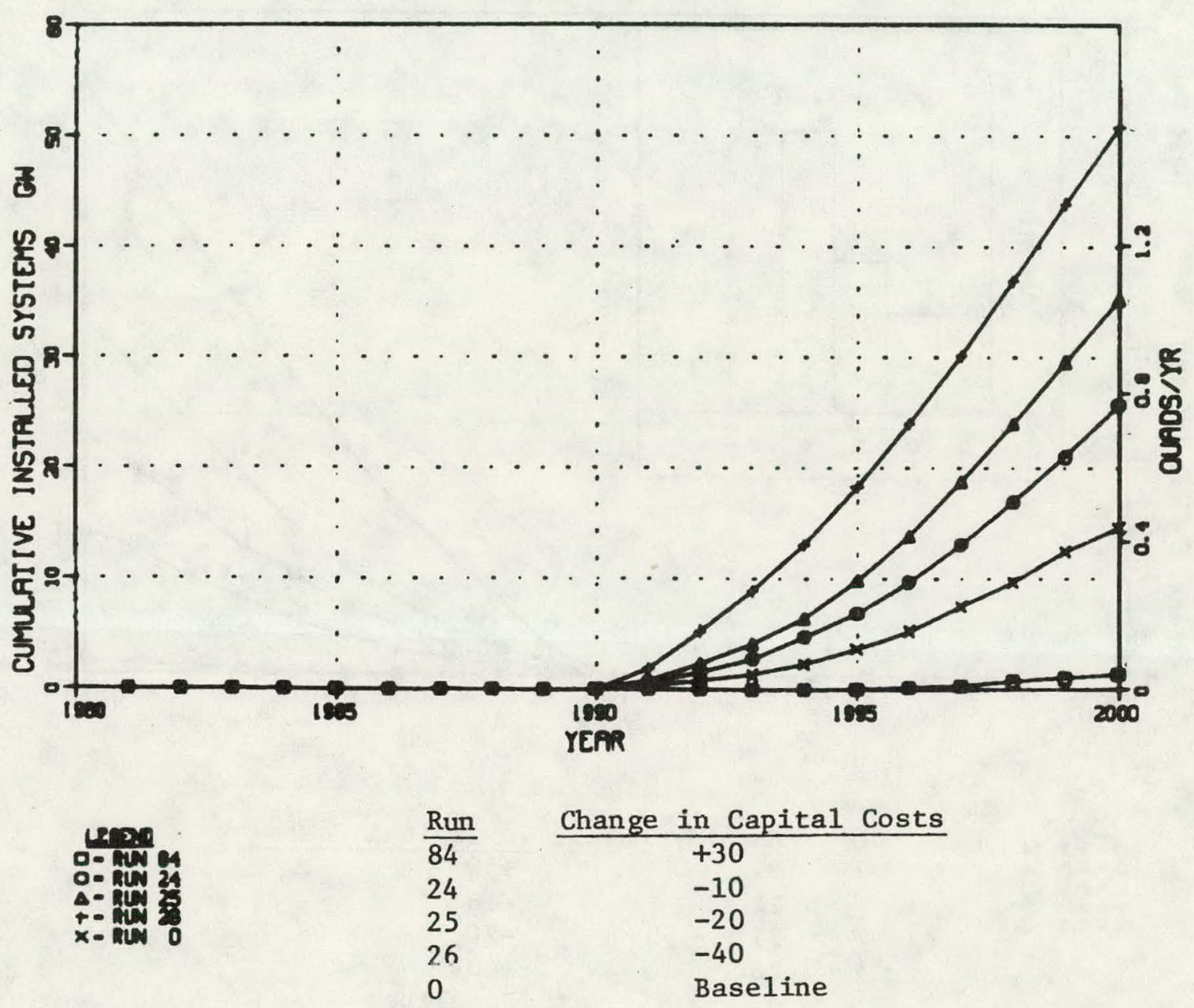

Figure 3-16. Photovoltaics, \% Capital Costs Change vs. Cumulative Installed Systems 


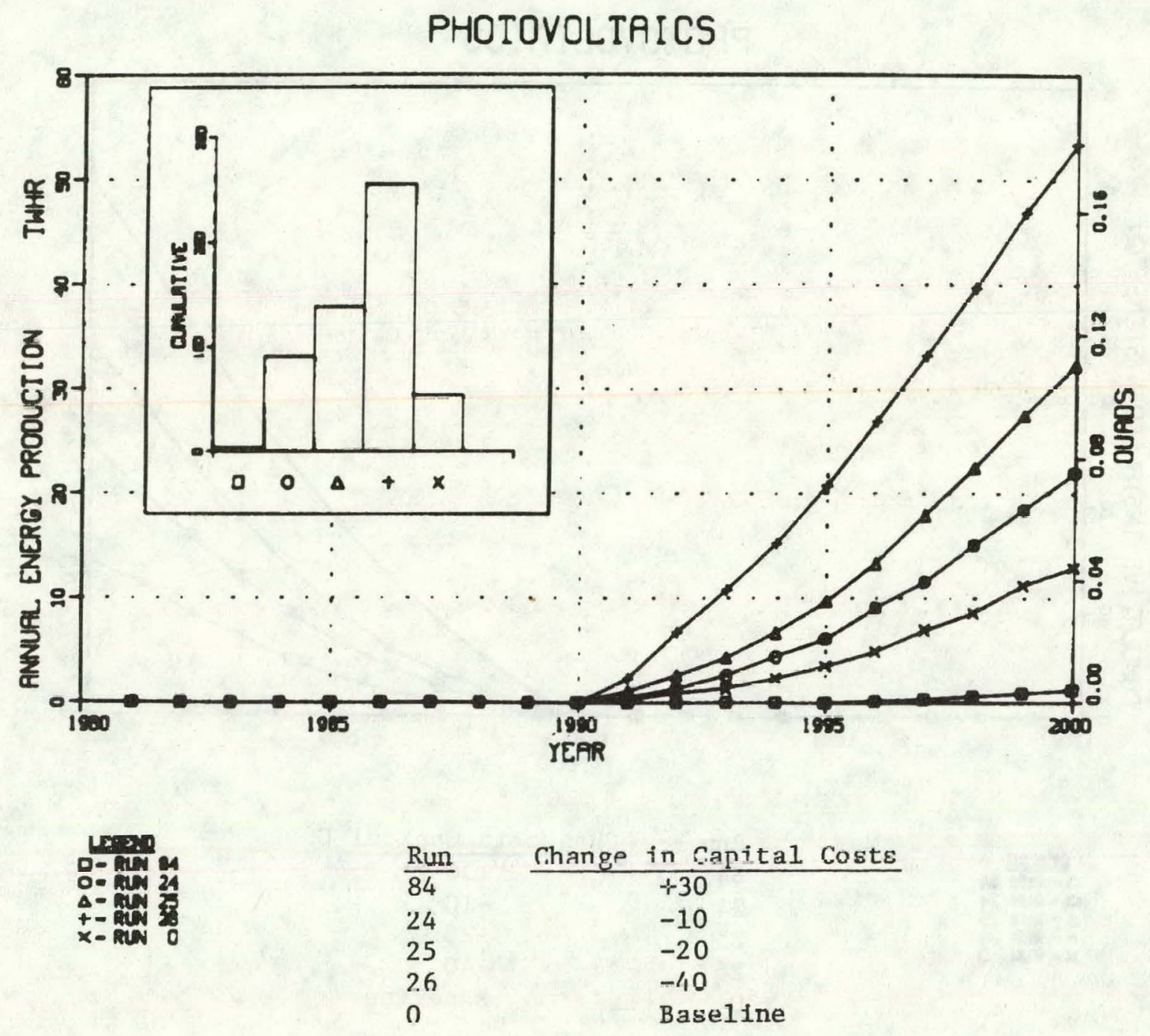

Figure 3-17. Photovoltaics, \% Capital Costs Change vs. Annual Energy Production 
PHOTOVOLTAICS
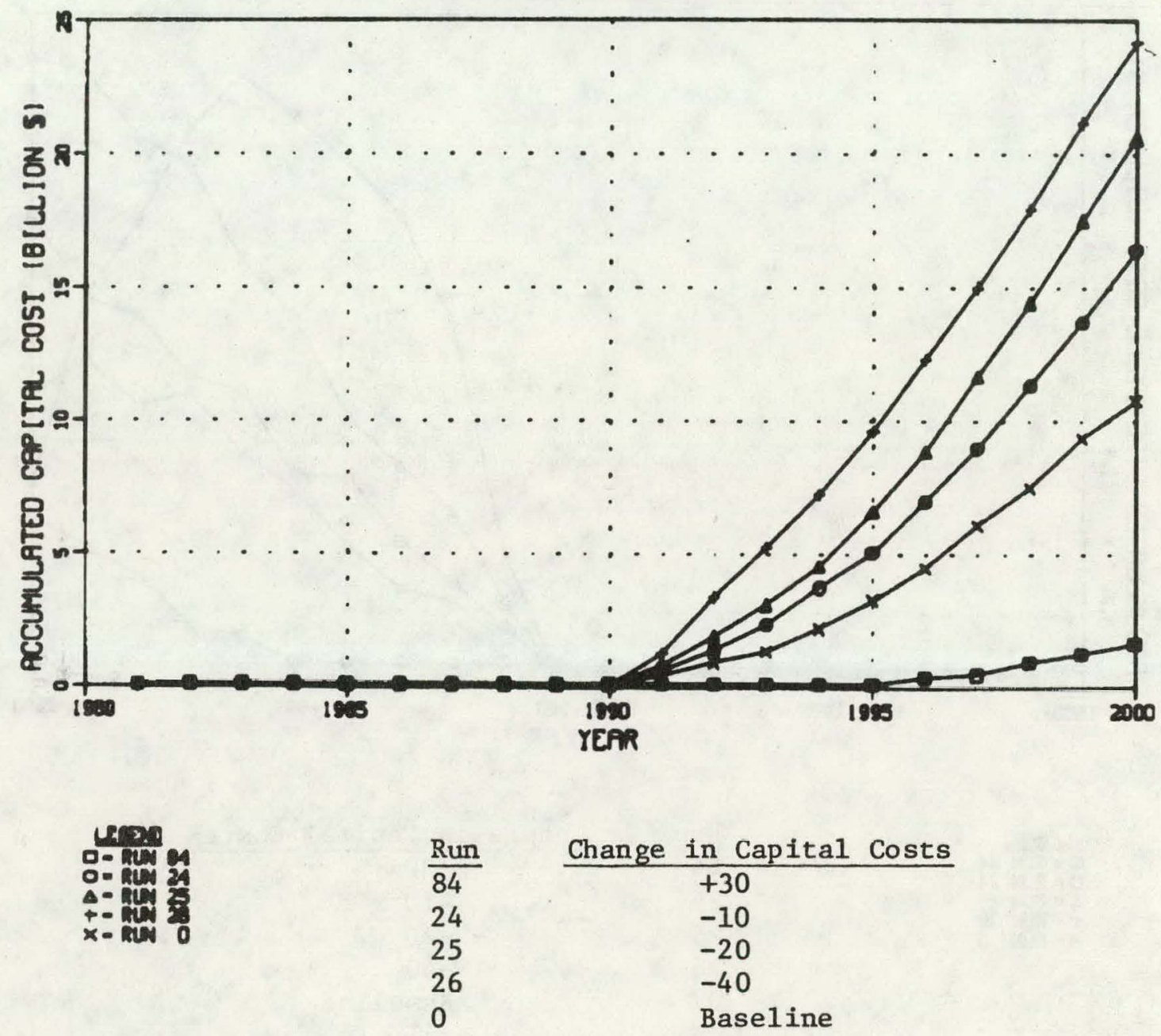

Figure 3-18. Photovoltaics, \% Capital Costs Change vs. Accumulated Capital Cost 
PHOTOVOLTAICS
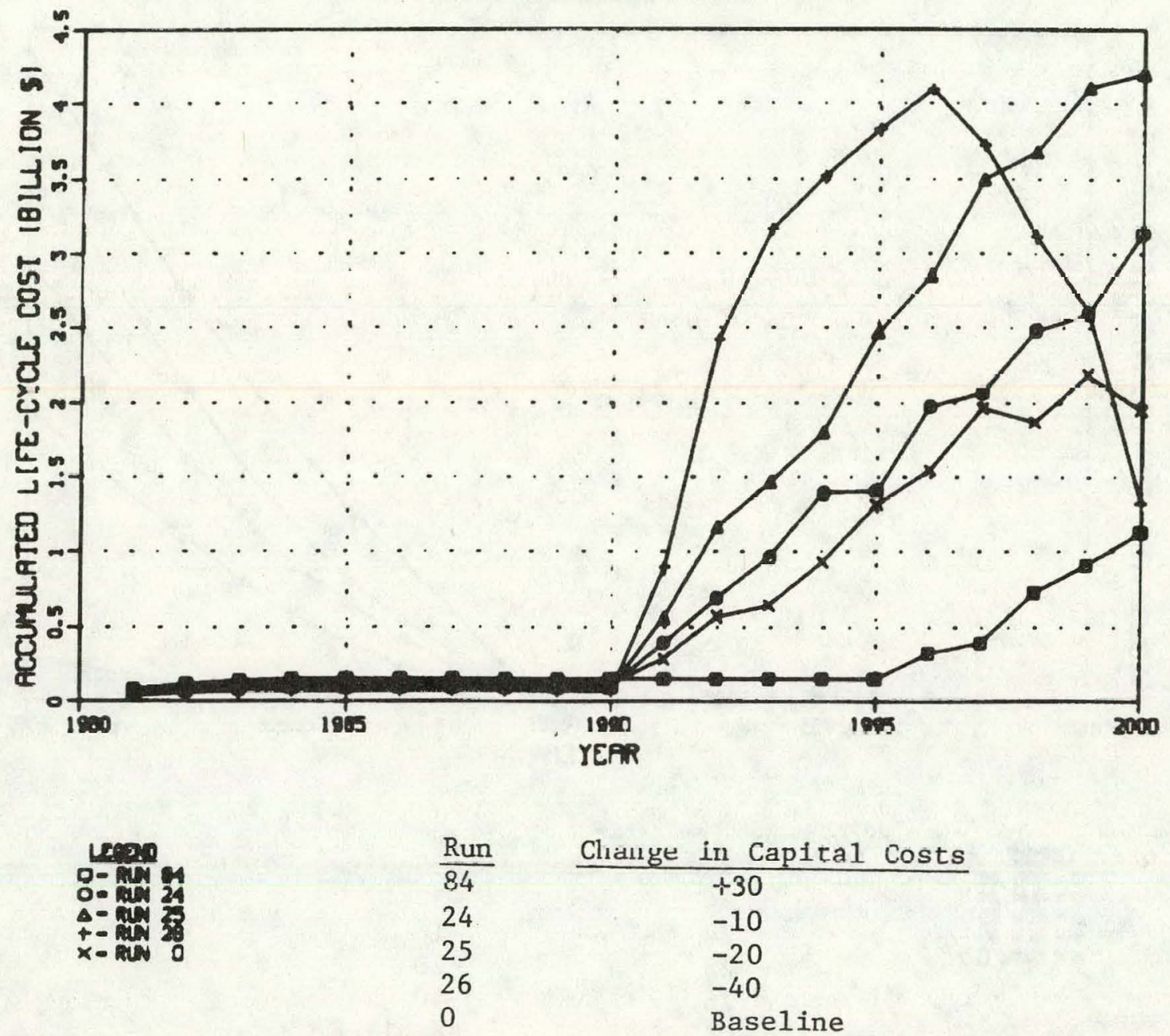

Figure 3-19. Photovoltaics, \% Capital Costs Change vs. Accumulated Life-Cycle Cost 


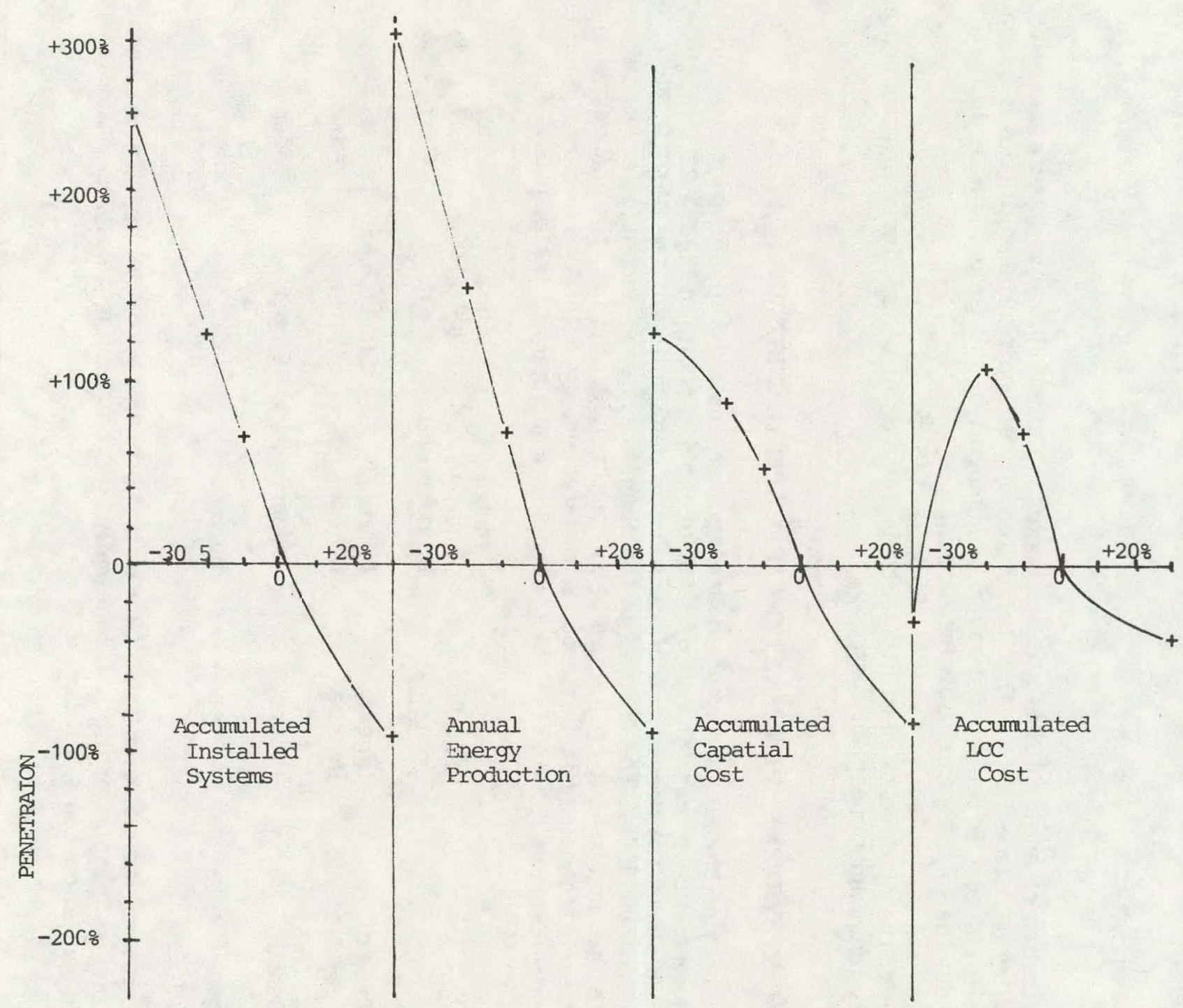

Figure 3-20. \% Change in Photovoltaic Utility Penetration Variables vs. \% Change in System Capital Cost for Year 2000 


\begin{tabular}{|c|c|c|c|c|}
\hline & $\begin{array}{c}\text { Acc. } \\
\text { Installed } \\
\text { Systems }\end{array}$ & $\begin{array}{c}\text { Annual } \\
\text { Energy } \\
\text { Produced } \\
\end{array}$ & $\begin{array}{c}\text { Acc. } \\
\text { Capital } \\
\text { Cost }\end{array}$ & $\begin{array}{l}\text { Acc. } \\
\text { LCC } \\
\text { Cost } \\
\end{array}$ \\
\hline $\begin{array}{l}\text { Type of } \\
\text { relationship }\end{array}$ & Linear & Linear & Linear & Nonlines \\
\hline Sense & Proper & Proper & Proper & Proper \\
\hline Sensitivity & $\begin{array}{l}\text { High } \\
6: 1\end{array}$ & $\begin{array}{l}\text { High } \\
7: 1\end{array}$ & $\begin{array}{l}\text { High } \\
3: 1\end{array}$ & Variable \\
\hline
\end{tabular}

The penetration of photovoltaics utilities begins in year 1990 due to input assumption of market entry date (see Table 2-4). The nonlinearity of photovol tairs utilities in accumulated life-cycle cost is due to fuel-saver tecluulugies in this group, similar to that discussed under the solar thermal utilities section.

In summary, the photovoltales-utility technologies exhibit a high, inversely proportional sensitivity to changes in capital cost.

\subsection{BIOMASS SYSTEMS* PENETRATION VS. CAPITAL COST}

The sensitivity of biomass systems* technology (see Table 2-3) penetration as a function of time to variation of capital cost of $-30 \%$ to $+50 \%$ is shown in Figs. $3-21$ through $3-24$. Figure 3-25 shows the percentage of variation in penetration of the SPURR output parameters for year 2000. The changes in the biomass systems* technologies were done as a group in this analysis but could have been done individually; i.e., the changes were the same for each technology in this group as the technology entered the marketplace (see market entry dates in Table 2-4). The following is a summary of the results:

\begin{tabular}{|c|c|c|c|c|}
\hline & $\begin{array}{c}\text { Acc. } \\
\text { Installed } \\
\text { Systems } \\
\end{array}$ & $\begin{array}{c}\text { Annual } \\
\text { Energy } \\
\text { Produced } \\
\end{array}$ & $\begin{array}{c}\text { Ace. } \\
\text { Capital } \\
\text { Cost } \\
\end{array}$ & $\begin{array}{l}\text { Acc. } \\
\text { LCC } \\
\text { Cost } \\
\end{array}$ \\
\hline $\begin{array}{l}\text { Type of } \\
\text { relationship }\end{array}$ & $\begin{array}{l}\text { Linear, } \\
\text { inverse }\end{array}$ & $\begin{array}{l}\text { Linear, } \\
\text { inverse }\end{array}$ & $\begin{array}{l}\text { Linear, } \\
\text { inverse }\end{array}$ & $\begin{array}{l}\text { Linear, } \\
\text { inverse }\end{array}$ \\
\hline Sense & Proper & Proper & Proper & Proper \\
\hline Sensitivity & $\begin{array}{l}\text { Low } \\
0.3: 1\end{array}$ & $\begin{array}{l}\text { Low } \\
0.3: 1\end{array}$ & $\begin{array}{l}\text { Low } \\
0.3: 1\end{array}$ & $\begin{array}{l}\text { Low } \\
0.3: 1\end{array}$ \\
\hline
\end{tabular}

Biomass systems technologies exhibit consistent behavior across all penetration variables (linear, inverse proportionality). Penetration of biomass is relatively insensitive to change in capital cost in SPURR.

*Group includes biomass utilities and synthetic products technologies. 
BIOMASS

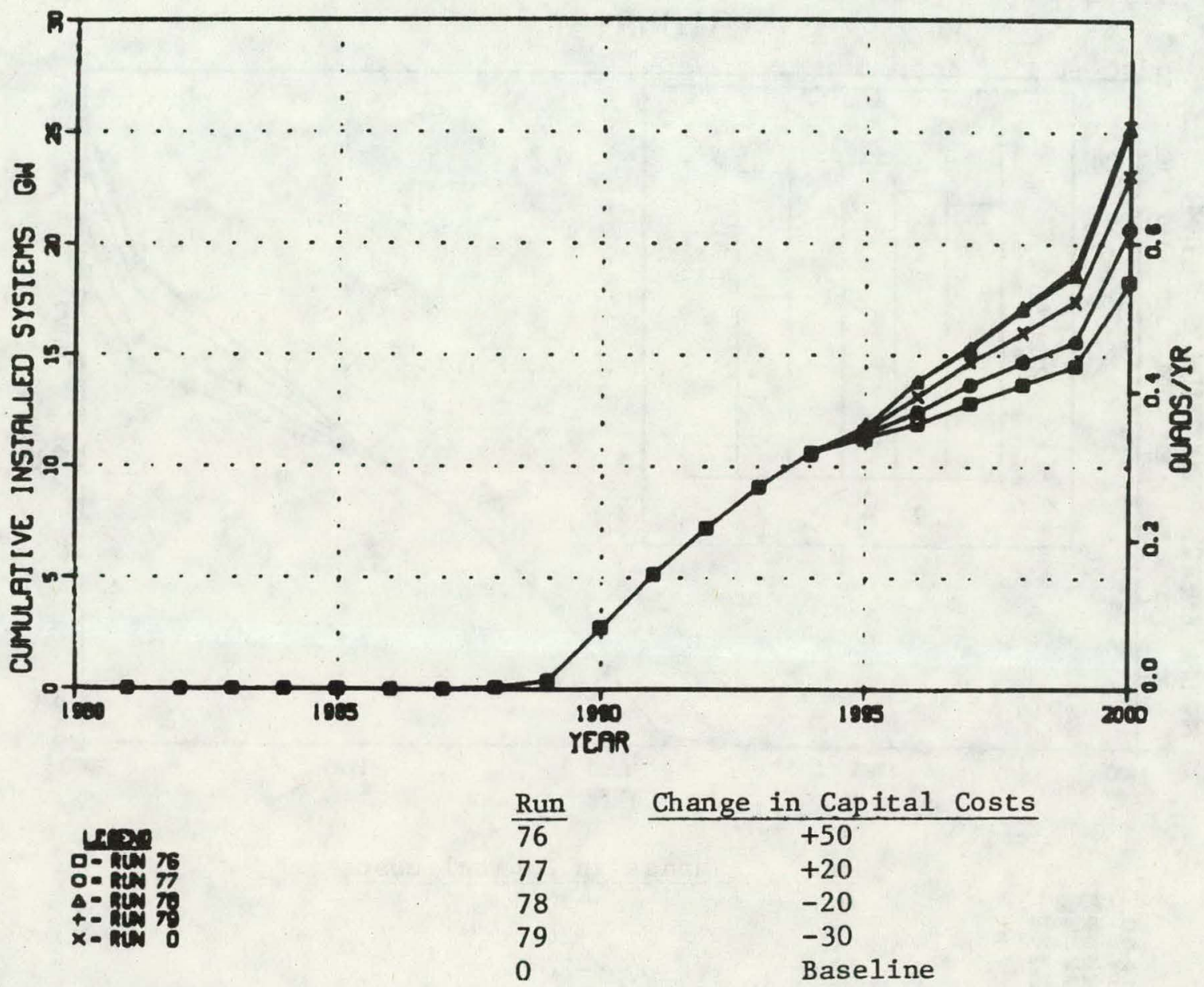

Figure 3-21. Biomass, \% Capital Costs Change vs. Cumulative Installed Systems 


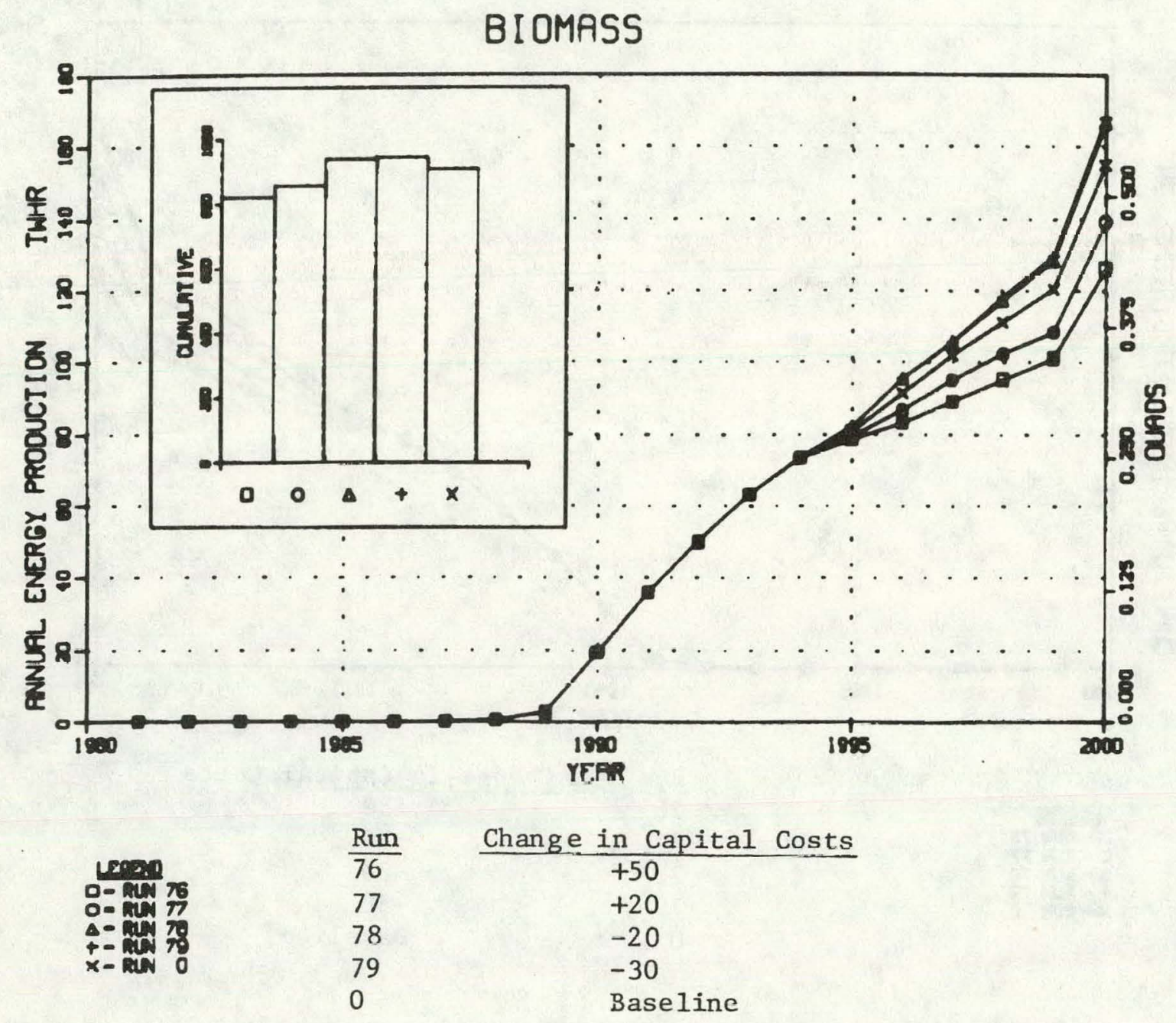

Figure 3-22. Biomass, \% Capital Costs Change vs. Annual Energy Production 


\section{BIOMASS}

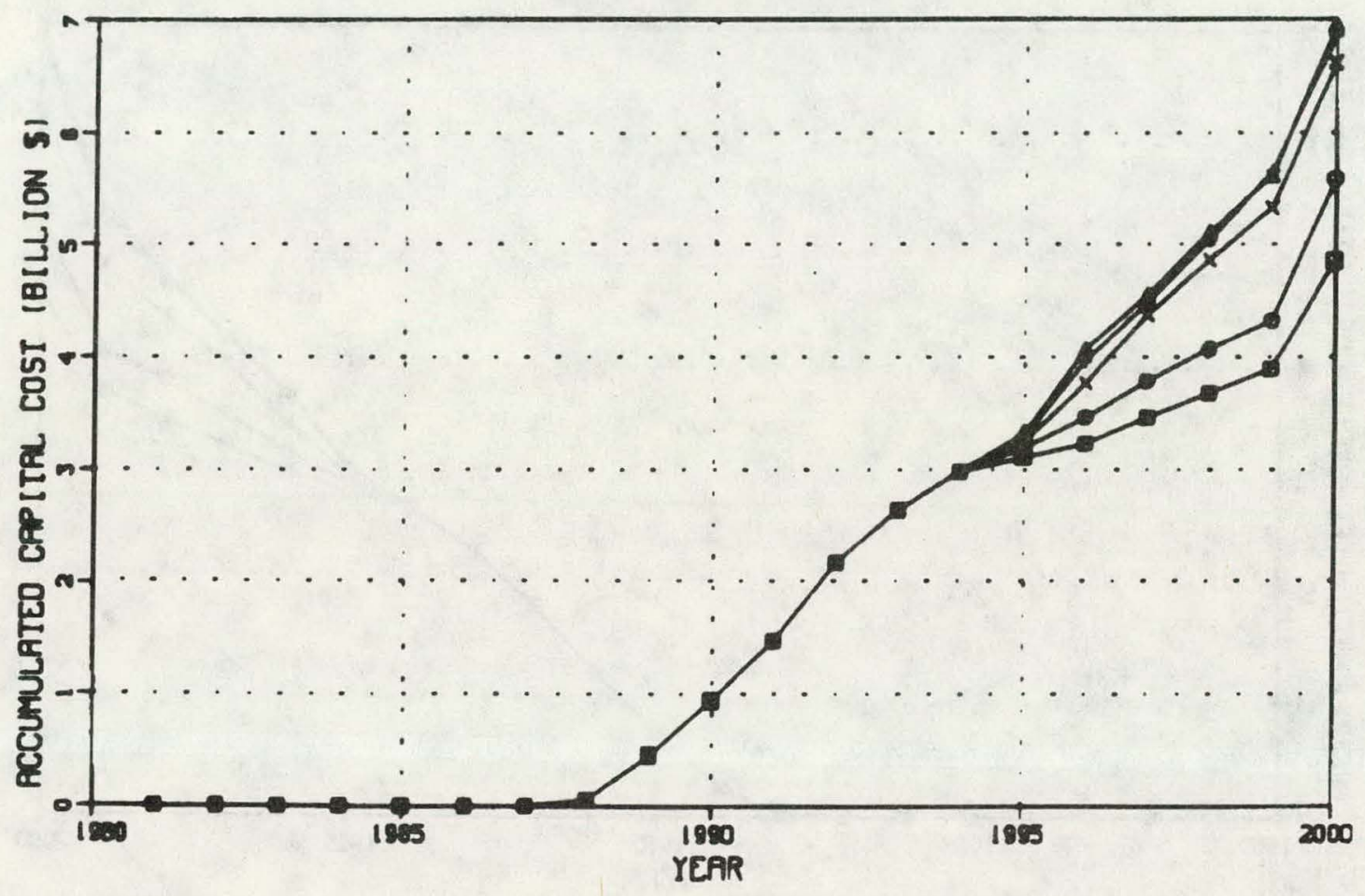

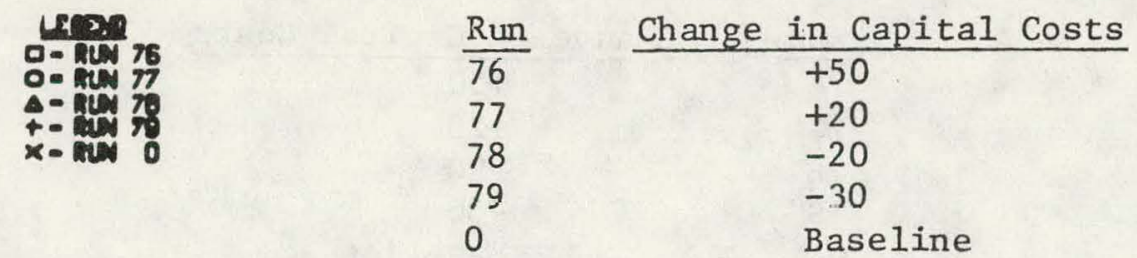

Figure 3-23. Biomass, \% Capital Costs Change vs. Accumulated Capital Costs 


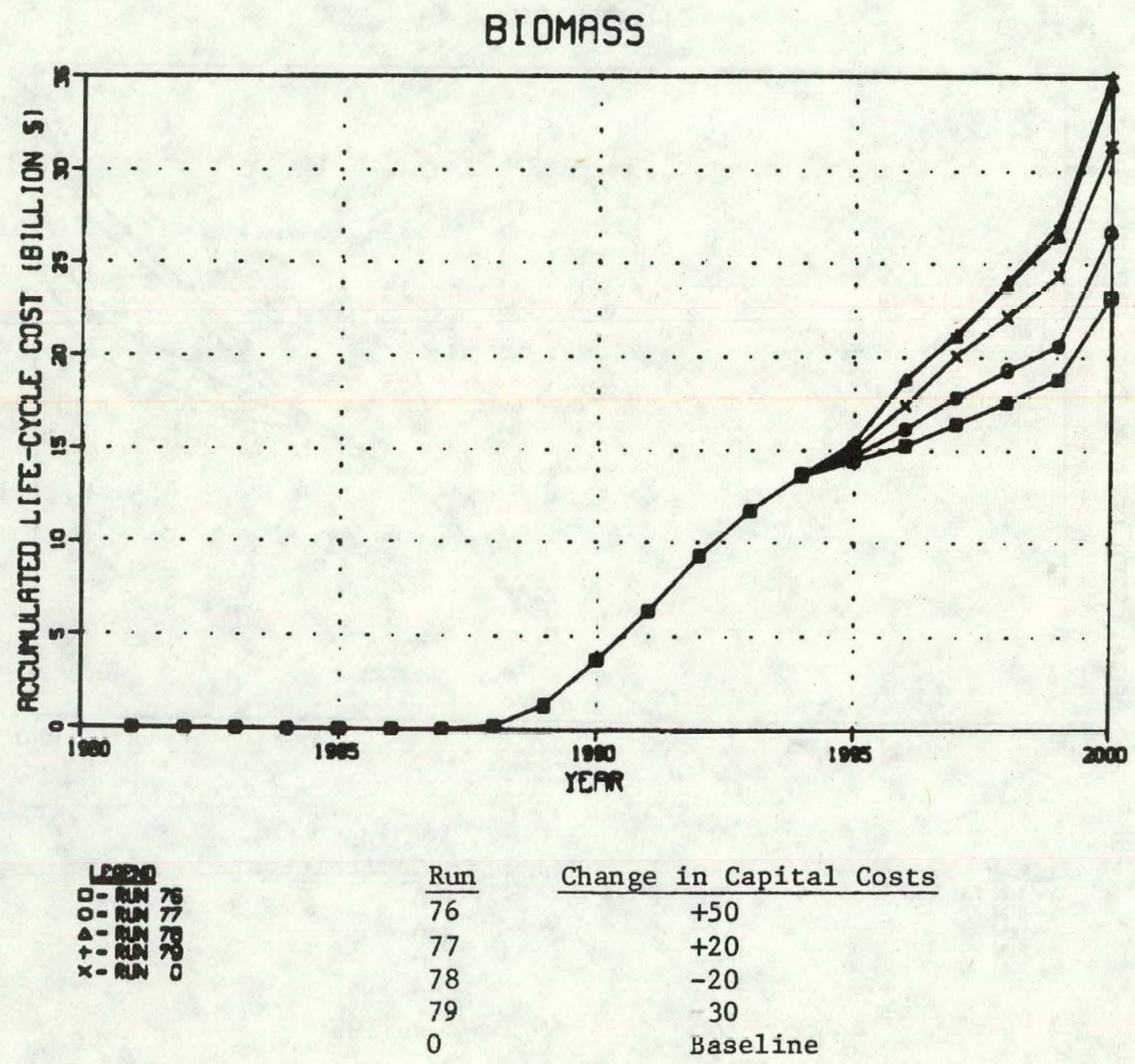

Figure 3-24. Biomass, \% Capital Costs Change vs. Accumulated Life-Cycle Cost 


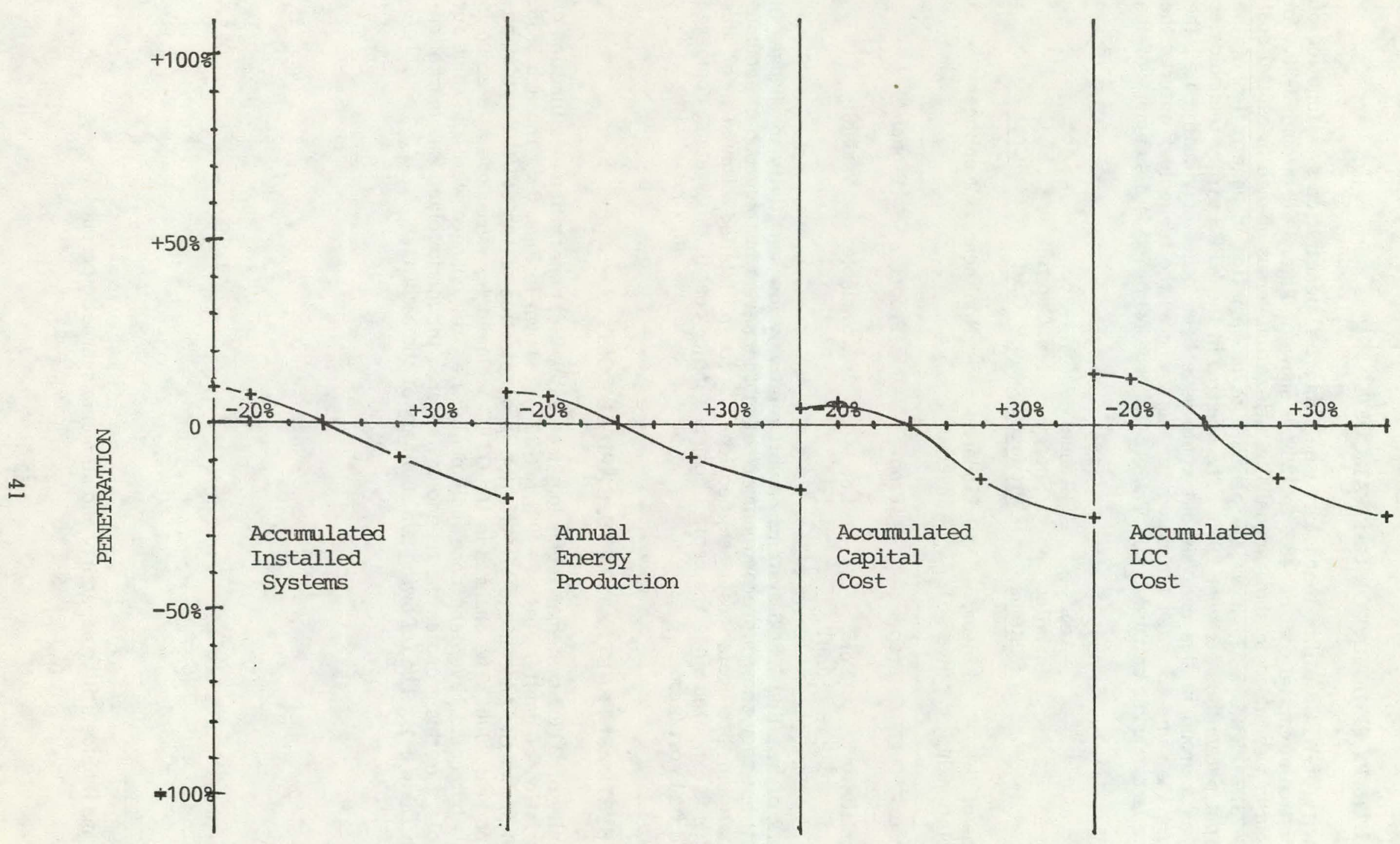

Figure 3-25. \% Change Biomass System Penetration Variables vs. \% Change in System Capital Cost for Year 2000 


\subsection{WECS UTIIITY PENETRATION CAPITAL COST}

The sensitivity of WECS utility technology (see Table 2-4) penetration as a function of time to variation of capital cost of $-46 \%$ to $+20 \%$ is shown in Figs. $3-26$ through 3-30. An additional curve was added to show annual fuel utilization versus change in capital cost (see Fig. 3-28). Figure 3-31 shows the percentage of variation in penetration of the SPURR output parameters for year 2000. The changes in the WECS utility technologies were done as a group in this analysis but could have been done individually; i.e., the changes were the same for each technology in this group as the technology entered the marketplace (see market entry dates in Table 2-4). The following is a summary of the resul ts:

\begin{tabular}{|c|c|c|c|c|}
\hline & $\begin{array}{c}\text { Acc. } \\
\text { Installed } \\
\text { Systems } \\
\end{array}$ & $\begin{array}{c}\text { Annual } \\
\text { Énergy } \\
\text { Produced } \\
\end{array}$ & $\begin{array}{c}\text { Acc. } \\
\text { Capital } \\
\text { Cust } \\
\end{array}$ & $\begin{array}{l}\text { Acc. } \\
\text { LCC } \\
\text { Cust } \\
\end{array}$ \\
\hline $\begin{array}{l}\text { Type of } \\
\text { relationship }\end{array}$ & $\begin{array}{l}\text { Lincar, } \\
\text { inverse }\end{array}$ & $\begin{array}{l}\text { Lincar, } \\
\text { inverse }\end{array}$ & Nonlinear & Nonlinear \\
\hline Sense & Proper & Proper & Proper & Proper \\
\hline Sensitivity & $\begin{array}{l}\text { Low } \\
0.5: 1\end{array}$ & $\begin{array}{l}\text { Low } \\
1: 1\end{array}$ & Variable & Variable \\
\hline
\end{tabular}

The numbers of installed WECS systems exhibit relatively low sensitivity to changes in capital cost, but they show a precominant effect of fuel savers in the group in accumulated capital and life-cycle cost (see Section 3.2 for a detailed discussion of this effect). This is expected since the capital cost is a major cost in this system, compared to $O \& M$ and fuel cost (zero).

\subsection{OTEC SYSTEMS* PENETRATION VS. CAPITAL COST}

The sensitivity of OTEC systems* technology (see Table 2-4) penetration as a function of time to variation of capital cost of $-40 \%$ to $+30 \%$ is shown in Figs. 3-32 through 3-35. Figure 3-36 shows the percentage of variation in penetration of the SPURR output parameters for year 2000. The changes in the OTEC technologies were done as a group in this analysis but could have been done individually; i.e., the changes were the same for each technology in this group as the technology entered the marketplace (see market entry dates in Table 2-4). The following is a summary of the results:

*OTEC systems include utili ty capability and ammonia synthetic products. 


\section{WECS}
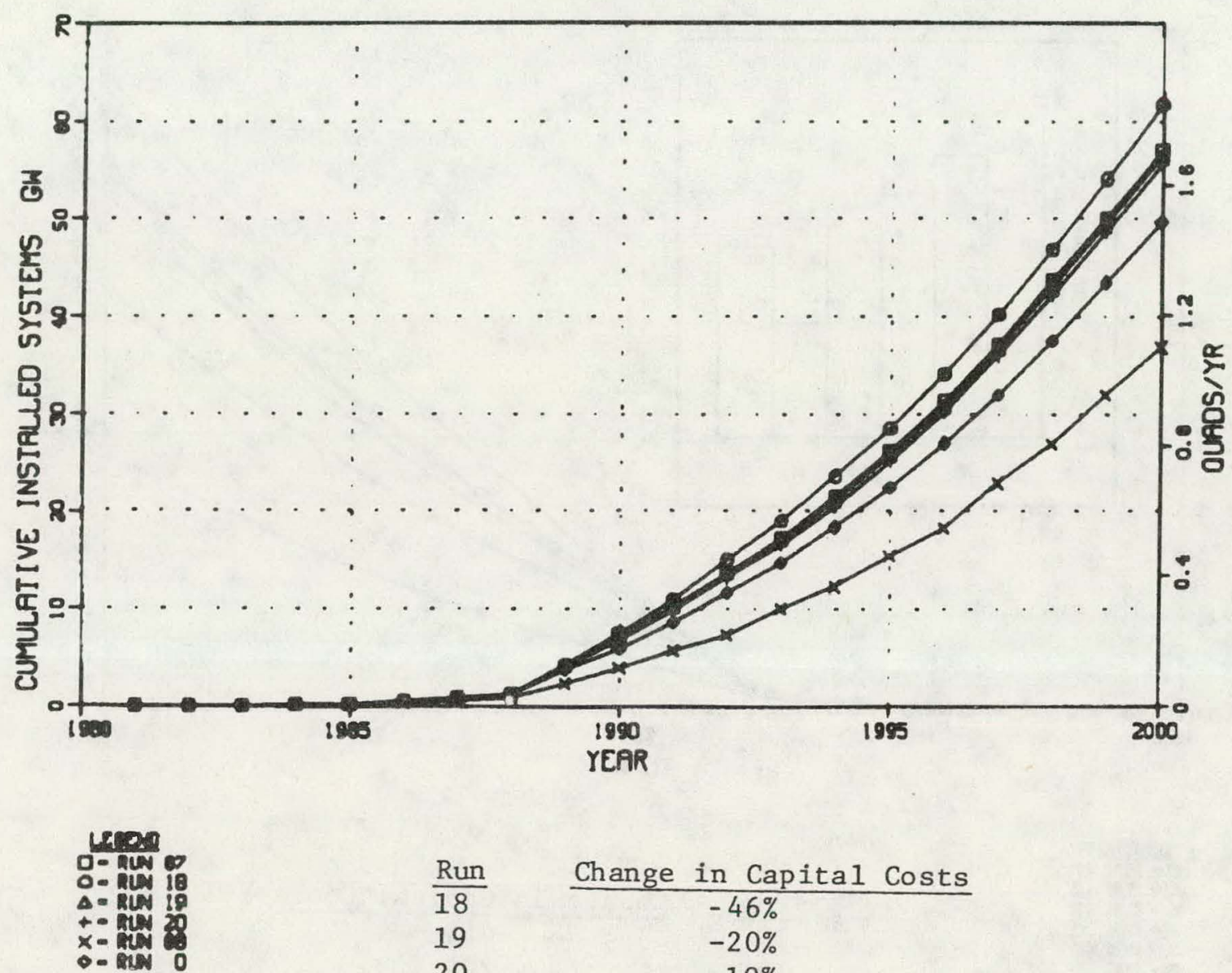

$\frac{\text { Run }}{18}$

19

20

87

88

0

\section{$\frac{\text { Change in Capital Costs }}{-46 \%}$}

$-20 \%$

$-10 \%$

$-30 \%$

$+20 \%$

Baseline

Figure 3-26. WECS, \% Capital Costs Change vs. Cumulative Installed Systems 

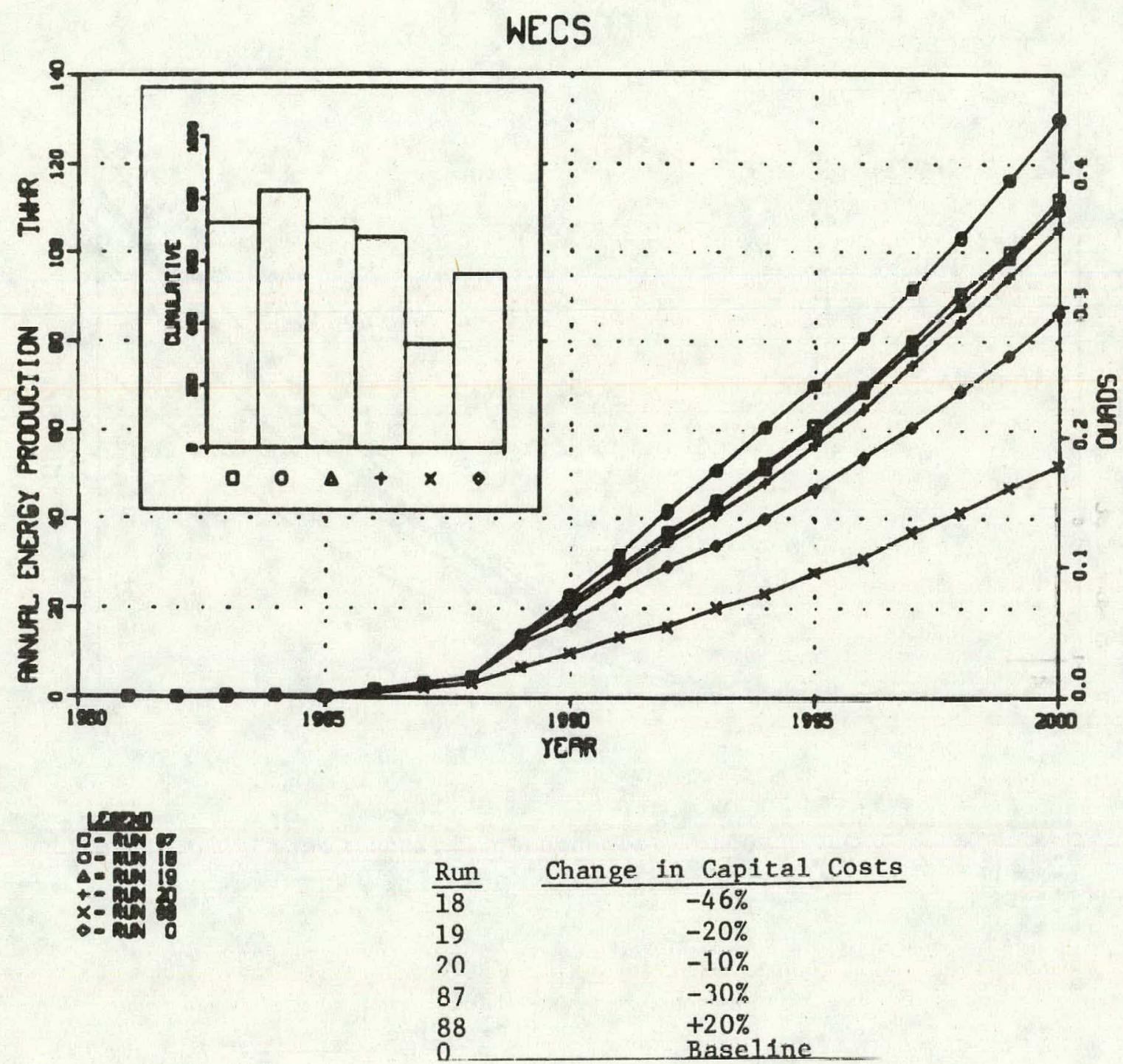

Figure 3-27. WECS, \% Capital Costs Change vs. Annual Energy Production 


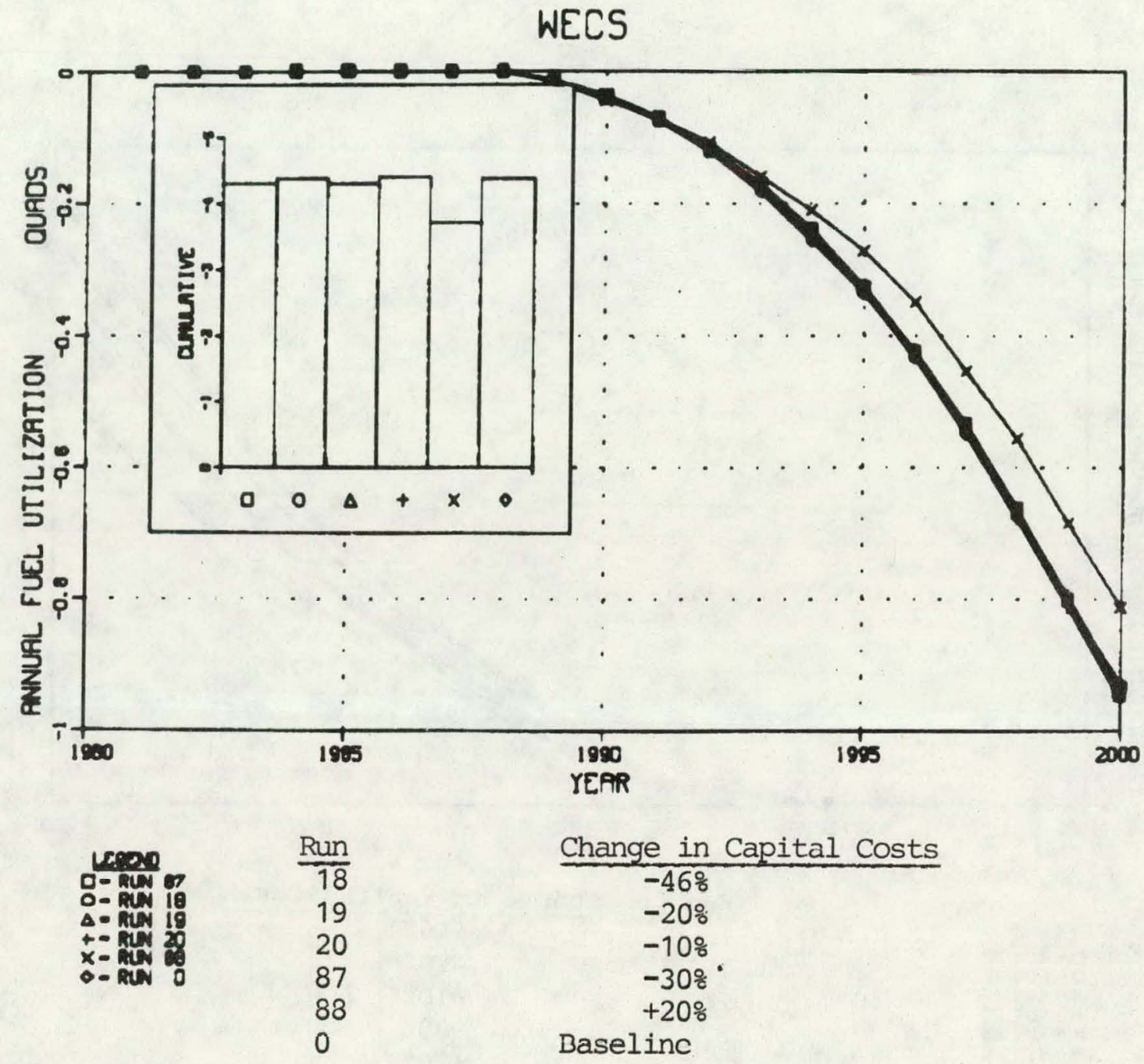

Figure 3-28. WECS, \% Capital Costs Change vs. Annual Fuel Utilization 
WECS

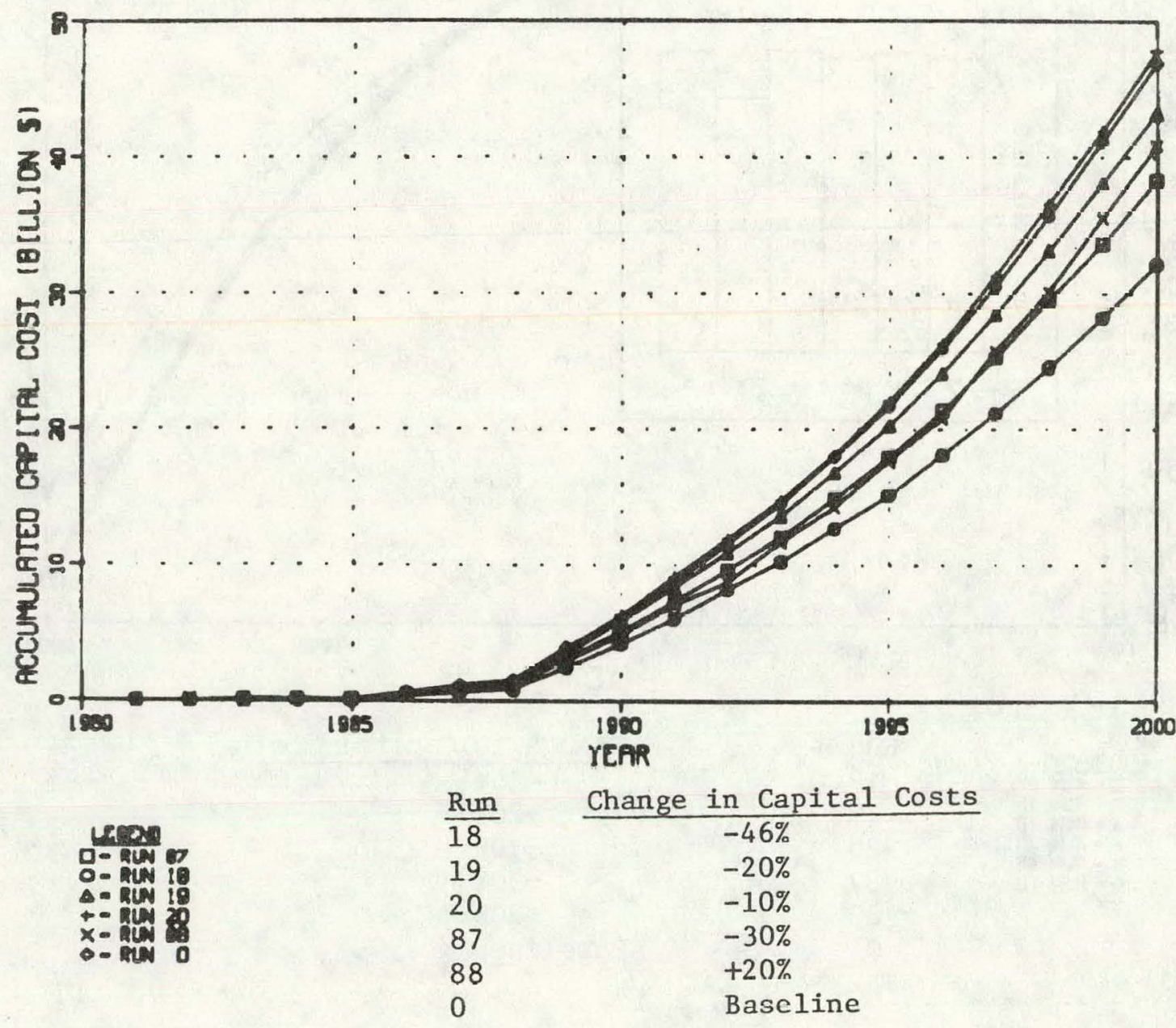

Figure 3-29. WECS, \% Capital Costs Change vs. Accumulated Capital Costs 


\section{WECS}

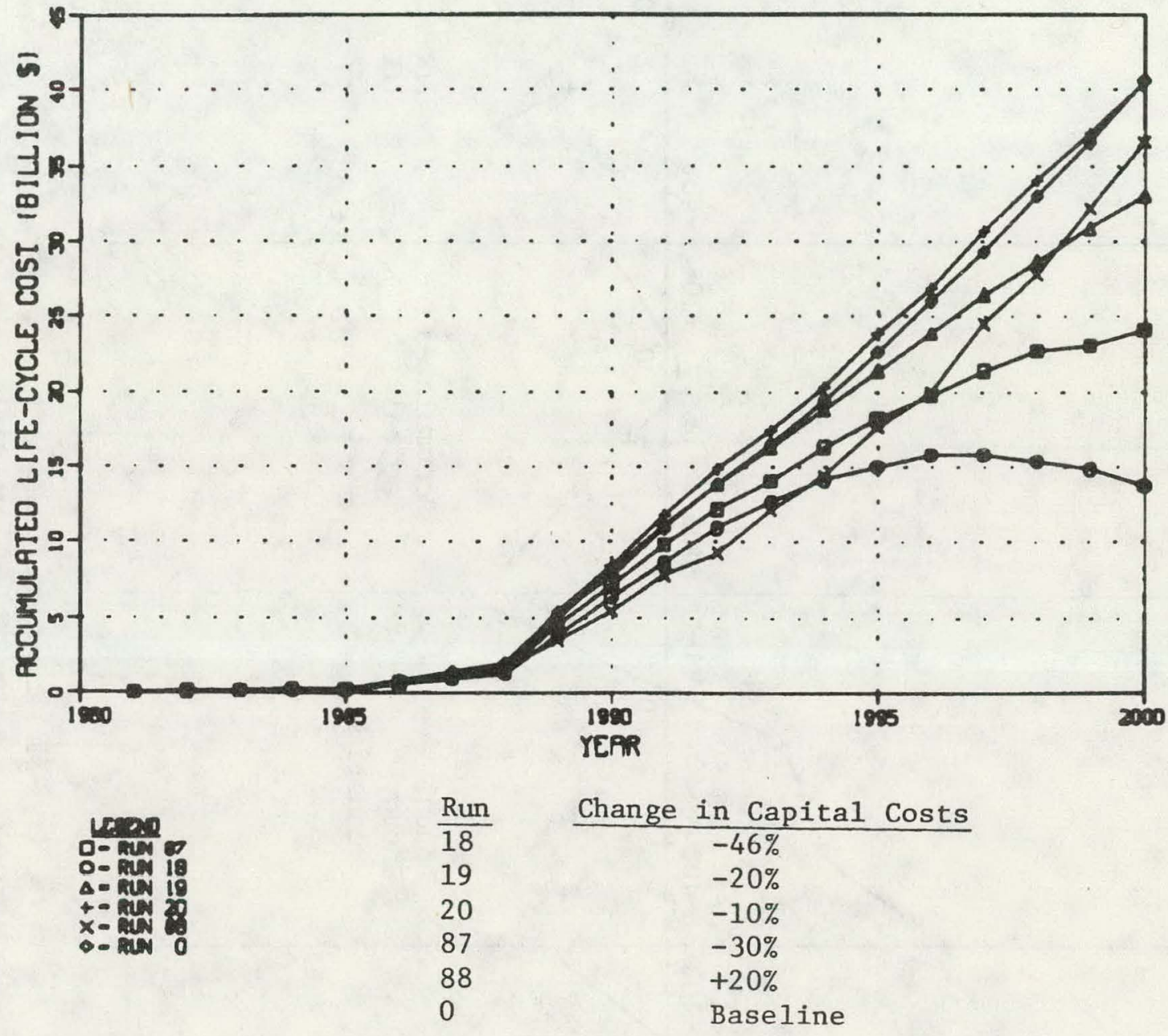

Figure 3-30. WECS, \% Capital Costs Change vs. Accumulated Life-Cycle Costs 


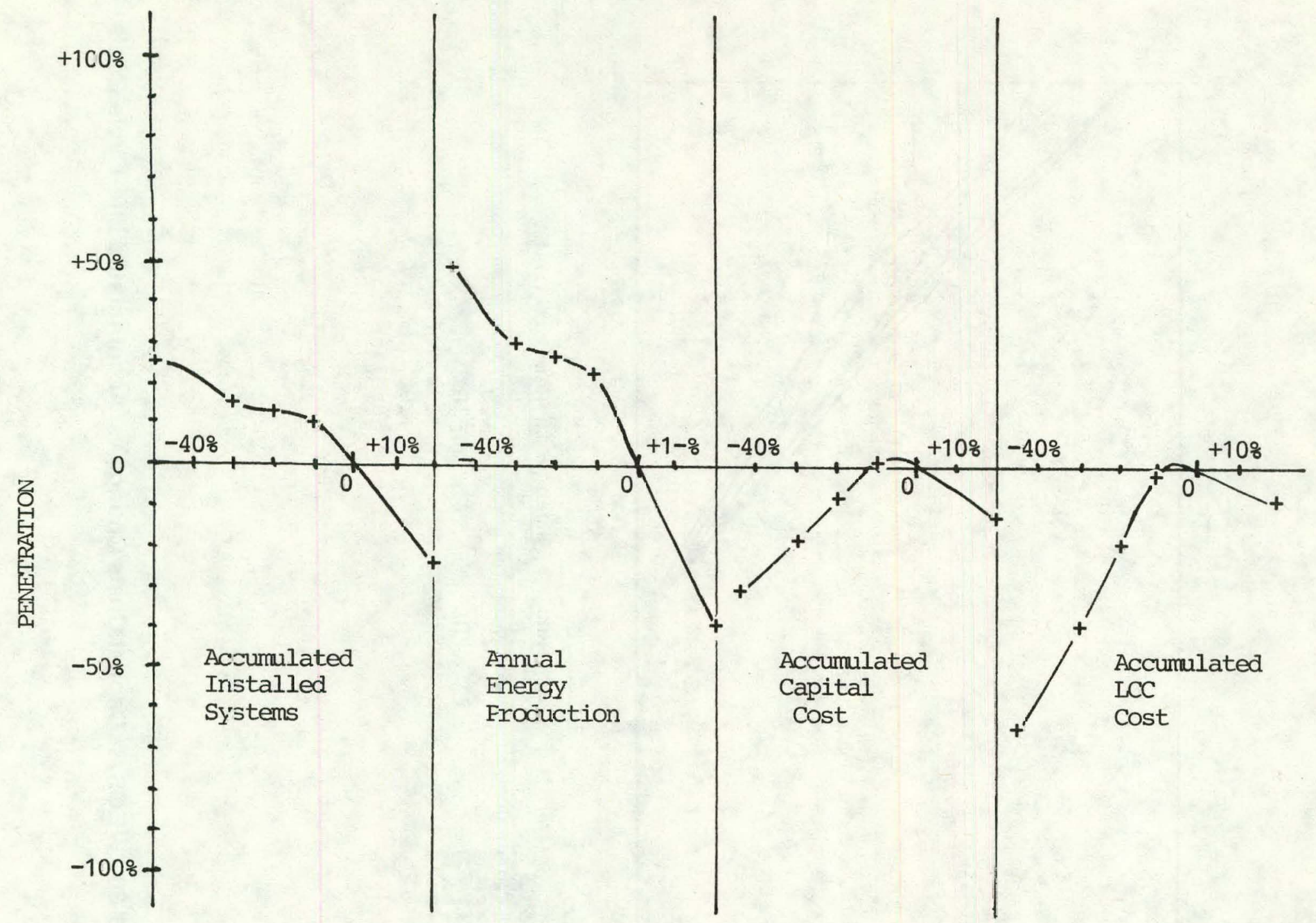

Figure 3-31. \% Change in WECS Systems Penetration Variables vs. $\%$ Change in System Capital Cost for Year 2000 
OTEC
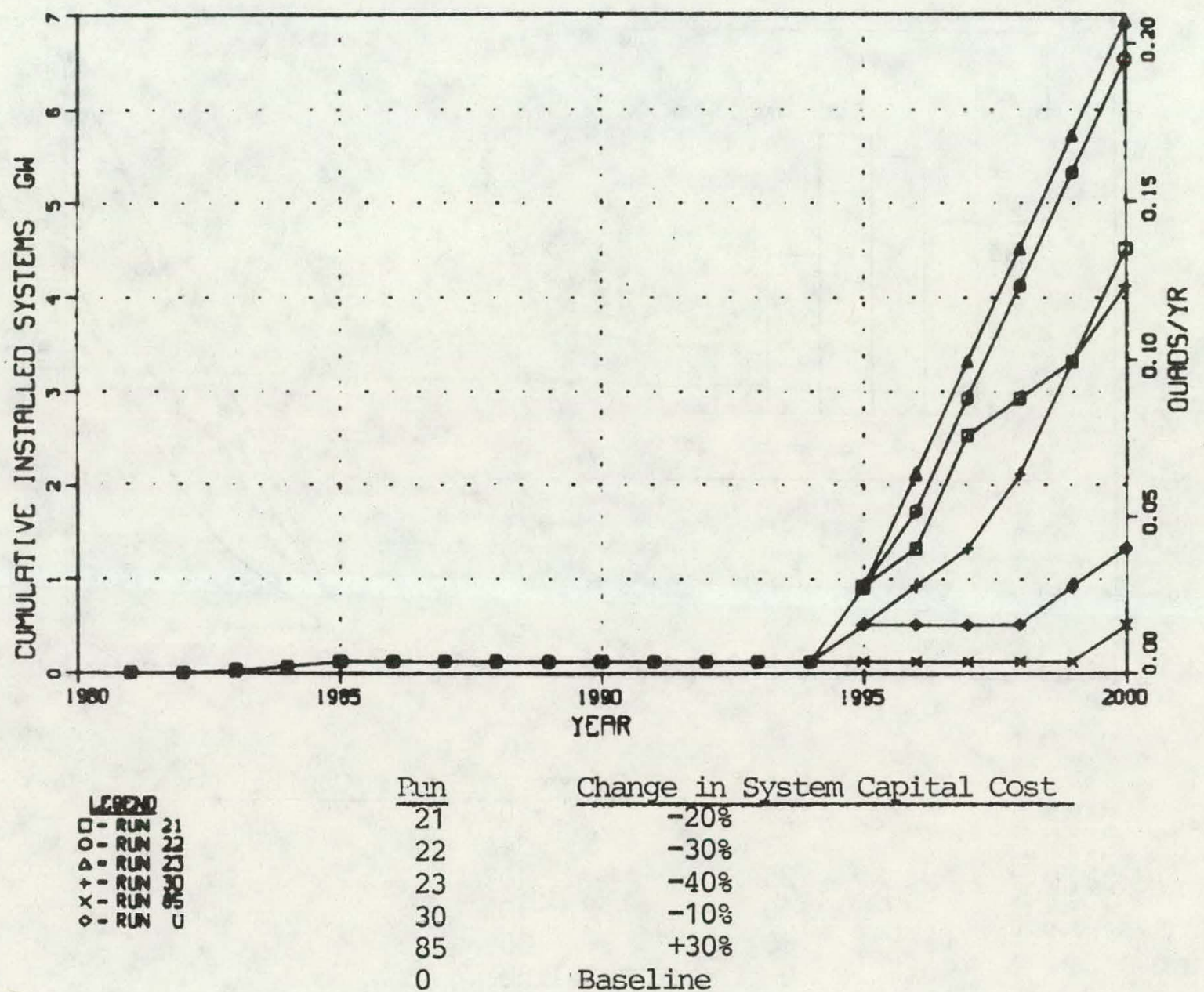

Figure 3-32. OTEC, \% System Capital Costs Change vs. Cumulative Installed System 


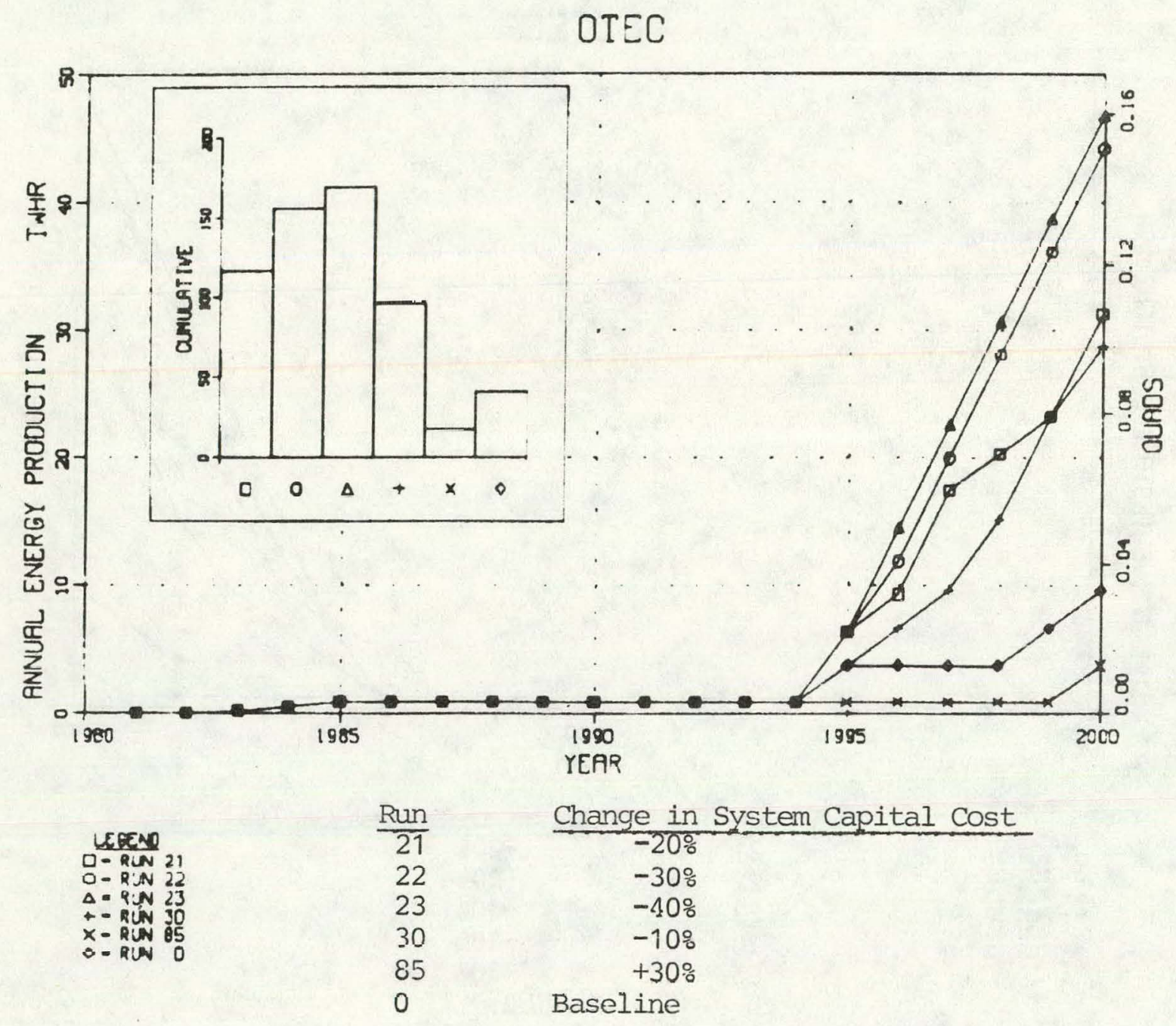

Figure 3-33. OTEC, \% System Capital Cost Change vs. Annual Energy Production 
OTEC

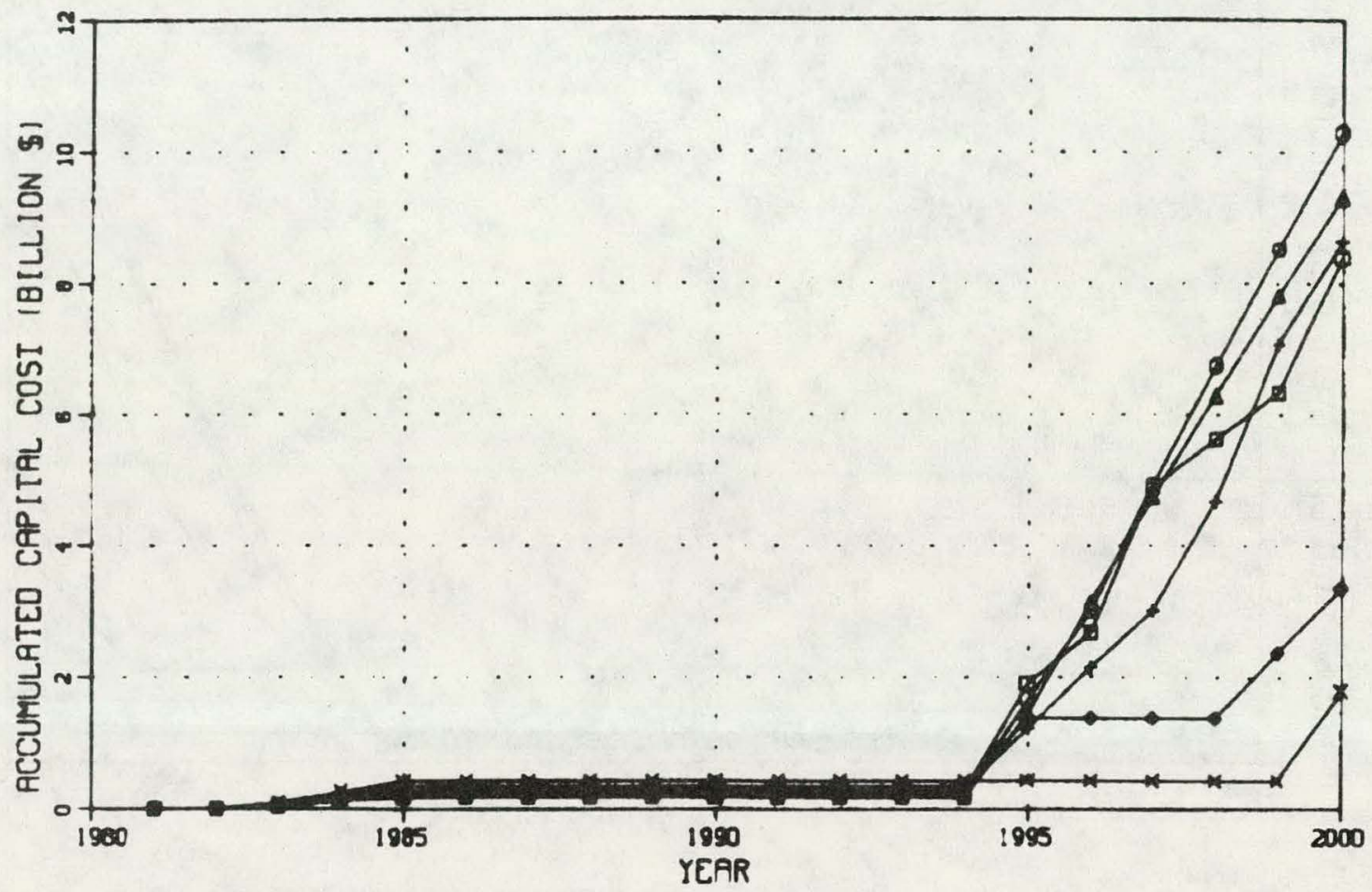

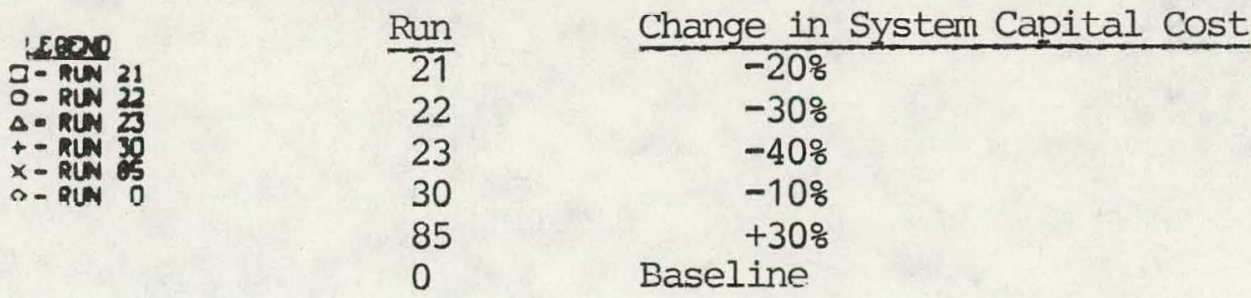

Figure 3-34. OTEC, \% System Capital Cost Change vs. Accumulated Capital Costs 
OTEC
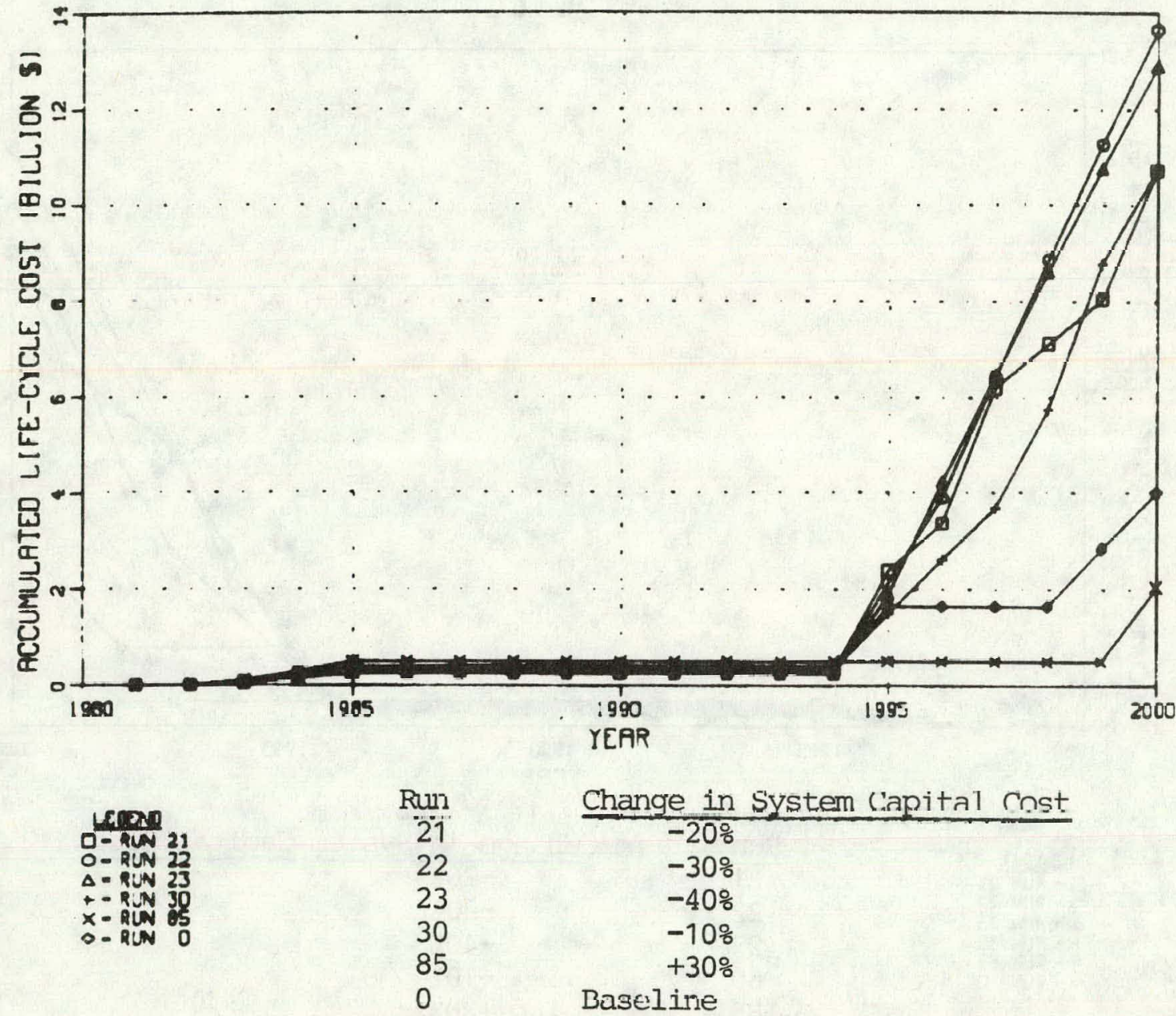

Figure 3-35. OTEC, \% System Capital Cost Change vs. Accumulated Life-Cycle Costs 


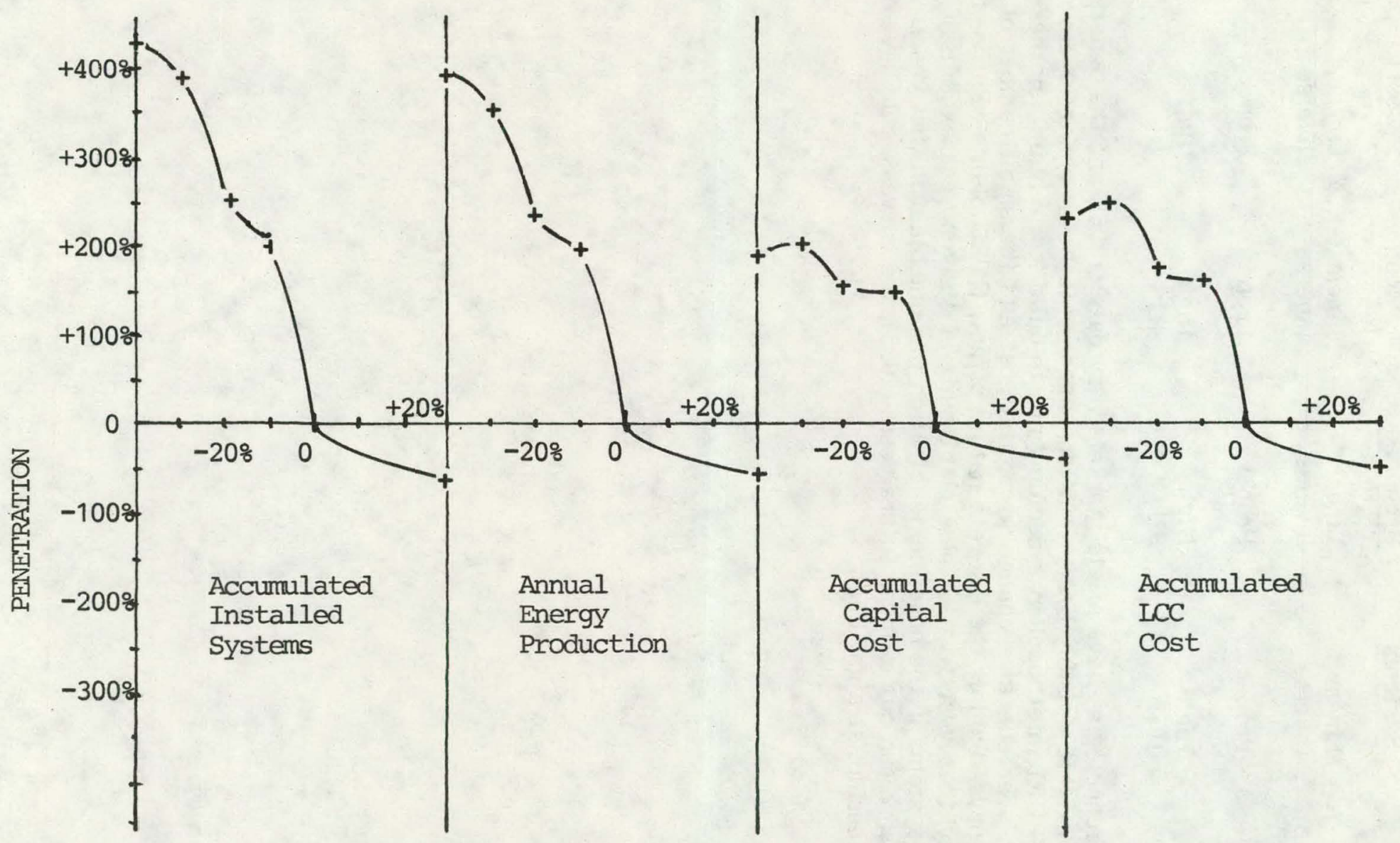

Figure 3-36. \% Change in OTEC System Penetration Variables vs. \% Change in System Capital Cost for Year 2000 


\begin{tabular}{|c|c|c|c|c|}
\hline & $\begin{array}{c}\text { Acc. } \\
\text { Installed } \\
\text { Systems }\end{array}$ & $\begin{array}{c}\text { Annual } \\
\text { Energy } \\
\text { Produced } \\
\end{array}$ & $\begin{array}{c}\text { Acc. } \\
\text { Capital } \\
\text { Cost }\end{array}$ & $\begin{array}{l}\text { Acc. } \\
\text { LCC } \\
\text { Cost } \\
\end{array}$ \\
\hline $\begin{array}{l}\text { Type of } \\
\text { relationship }\end{array}$ & $\begin{array}{l}\text { Linear,* } \\
\text { inverse }\end{array}$ & $\begin{array}{l}\text { Linear,* } \\
\text { inverse }\end{array}$ & $\begin{array}{l}\text { Linear,* } \\
\text { inverse }\end{array}$ & $\begin{array}{l}\text { Linear,* } \\
\text { inverse }\end{array}$ \\
\hline Sense & Proper & Proper & Proper & Proper \\
\hline Sensi tivity & $\begin{array}{l}\text { High } \\
10: 1\end{array}$ & $\begin{array}{l}\text { High } \\
9: 1\end{array}$ & $\begin{array}{l}\text { High } \\
4: 1\end{array}$ & $\begin{array}{l}\text { High } \\
4: 1\end{array}$ \\
\hline
\end{tabular}

In SPURR, OTEC technologies have a late market entry date (1995), and the penetration percentages do not exhibit a visibly linear relationship to capital cost changes. However, this is due to the SPURR methodology's deciding not to build (or to build) anotlier plunt or plants in a given year due to a change in capital cost and the small number of total plants built. The curves exhibit the discrete nature of new OTEC plants rclative to the total plants built by that year (e.g., a new plant buil t in a given year exhibits a 100\% change in installed systems if the baseline penetration was one plant in that year). Thus, if the penetration were run out to more future years (2025), the curves would have shown a more linear relationship (straight line).

*See explanation in text. 


\section{SECTION 4.0}

\section{ANNUAL O\&M COST SENSITTVITY ANALYSIS}

Annual O\&M cost was varied in each SPURR sector* to evaluate the effects on the following SPURR variables:

- accumulated installed systems (million $\mathrm{ft}^{2}$ or $\mathrm{GW}$ ),

- annual energy production (TWh or quads/yr),

- accumulated capital cost (\$), and

- accumulated life-cycle cost (\$).

Two other penetration variables also were calculated as a function of variation in O\&M cost. Annual fuel utilized is shown for WECS only (the data for both variables are available upon request). Accumulated installed systems are a measure of the number of systems installed.

Annual energy production measures the total energy production of all plants in a specific year. Accumulated capital cost is the total capital cost of all plants built up to a specific year. Accumulated federal expense is the amount of federal money lost due to tax credits. Annual fuel utilization measures the amount of fuel burned. (Annual fuel utilized is given only for WECS systems to show the effect of saving fuel.) Accumulated life-cycle cost is the total life-cycle cost of systems installed at that time; it includes capital cost, O\&M, and fuel cost over the lifetime of the plant.

The data in this section are presented in two ways: (1) variation of penetration in real units as a function of time (1980 to 2000) and (2) percentage change from baseline scenario (penetration) versus percentage change in annual O\&M cost. The only technology showing high sensitivity (ratio of percentage in penetration versus percentage change in O\&M cost) was OTEC. OTEC showed extreme sensitivity on a percentage basis, but this may be due to the small number of plants buil t (i.e., a change of one plant when two were built causes a $50 \%$ change in installed systems). All other technologies showed low sensitivity to changes in O\&M cost. (See Tables 2-1 and 2-4 for a range of baseline O\&M costs in the SPURR data base and the grouping of technologies in each category.)

In addition to displaying the data, the results were analyzed in a qualitative and quantitative fashion according to three criteria: type of relationship, sense, and sensitivity. Type of relationship indicates whether the change in penetration was linear or nonlinear with respect to change in O\&M cost. Sense attempts to evaluate the direction of change in penetration with respect to intuitive feel about penetration; i.e., if O\&M cost increases, then one feels that fewer systems should be built, or vice versa. This analysis of sense involves looking for obvious errors in the SPURR methoiology. The final evaluation uses sensitivity in a qualitative (high, low, moderate, none) and a quantitative sense (if change was linear) by reporting the proportionality of the change in penetration with the change in O\&M cost. Some sensitivities were as high as 3:1 (see OTEC) and some as low as 0.2:1 (see WECS).

\footnotetext{
*A later revision of this report will include the SHACOB data.
} 
Even though OTEC market penetration is sensitive to O\&M cost, the other solar technologies are relatively insensitive to changes in $O \& M$ cost. Estimates of $O \& M$ cost in future technologies have been known to have the greatest uncertainty in the SPURR data base; yet by doing the analysis, the penetration of these technologies does not vary more than $10 \%$ by year 2000 .

\subsection{PROCESS HEAT SYSTEMS PENETRATION VS. ANNUAL O\&M COST}

The sensitivity of process heat systems (all are solar thermal technologies, see Table 2-1) penetration as a function of time to variation in annual O\&M cost of $-30 \%$ to $+50 \%$ is shown in Figs. 4-1 through 4-4. Figure 4-5 shows the percentage variation in penetration of the SPURK output parameters for the year 2000. The changes in the process heat technologies were done as a group, but they could have been treated individually; i.e., the changes were the same for each technology in this group as the technology entered the marketplace (see market entry dates in Table 2-1). The following is a summary of the resul ts:

\begin{tabular}{|c|c|c|c|c|}
\hline & $\begin{array}{c}\text { Acc.* } \\
\text { Installed } \\
\text { Systems } \\
\end{array}$ & $\begin{array}{c}\text { Annual } \\
\text { Energy } \\
\text { Produced } \\
\end{array}$ & $\begin{array}{c}\text { Acc. } \\
\text { Capital } \\
\text { Cost } \\
\end{array}$ & $\begin{array}{l}\text { Acc. } \\
\text { LCC } \\
\text { Cost } \\
\end{array}$ \\
\hline $\begin{array}{l}\text { Type of } \\
\text { relationship }\end{array}$ & $\begin{array}{l}\text { Linear, } \\
\text { inverse }\end{array}$ & $\begin{array}{l}\text { Linear, } \\
\text { inverse }\end{array}$ & $\begin{array}{l}\text { Linear, } \\
\text { inverse }\end{array}$ & Linear \\
\hline Sense & Proper & Proper & Proper & Proper \\
\hline Sensitivity & $\begin{array}{l}\text { Low } \\
0.2: 1\end{array}$ & $\begin{array}{l}\text { Low } \\
0.2: 1\end{array}$ & $\begin{array}{l}\text { Low } \\
0.2: 1\end{array}$ & None \\
\hline
\end{tabular}

In summary, the penetration of process heat systems is relatively insensitive to changes in O\&M cost and does not affect accumulated life-cycle cost (see Fig. 4-5).

\subsection{SOLAR THERMAL UTHITIES PENETRATION VS. ANNUAL O\&M COST}

The sensitivity of solar thermal utilities technologies (see Table 2.2) penetration as a function of time to variation in annual O\&M cost of $-30 \%$ to $+50 \%$ is shown in Figs. 4-6 through 4-9. Figure 4-10 shows the percentage variation in penetration of the SPURR output parameters for the year 2000. The changes in the solar thermal utility technologies were done as a group in this analysis but could have been done individually; i.e., the. changes were the same for each technology in this group as the technology entered the marketplace (see market entry dates in Table 2-1). The following is a summary of the results:

*Accumulated (Acc.). 


\section{PROCESS HEAT}

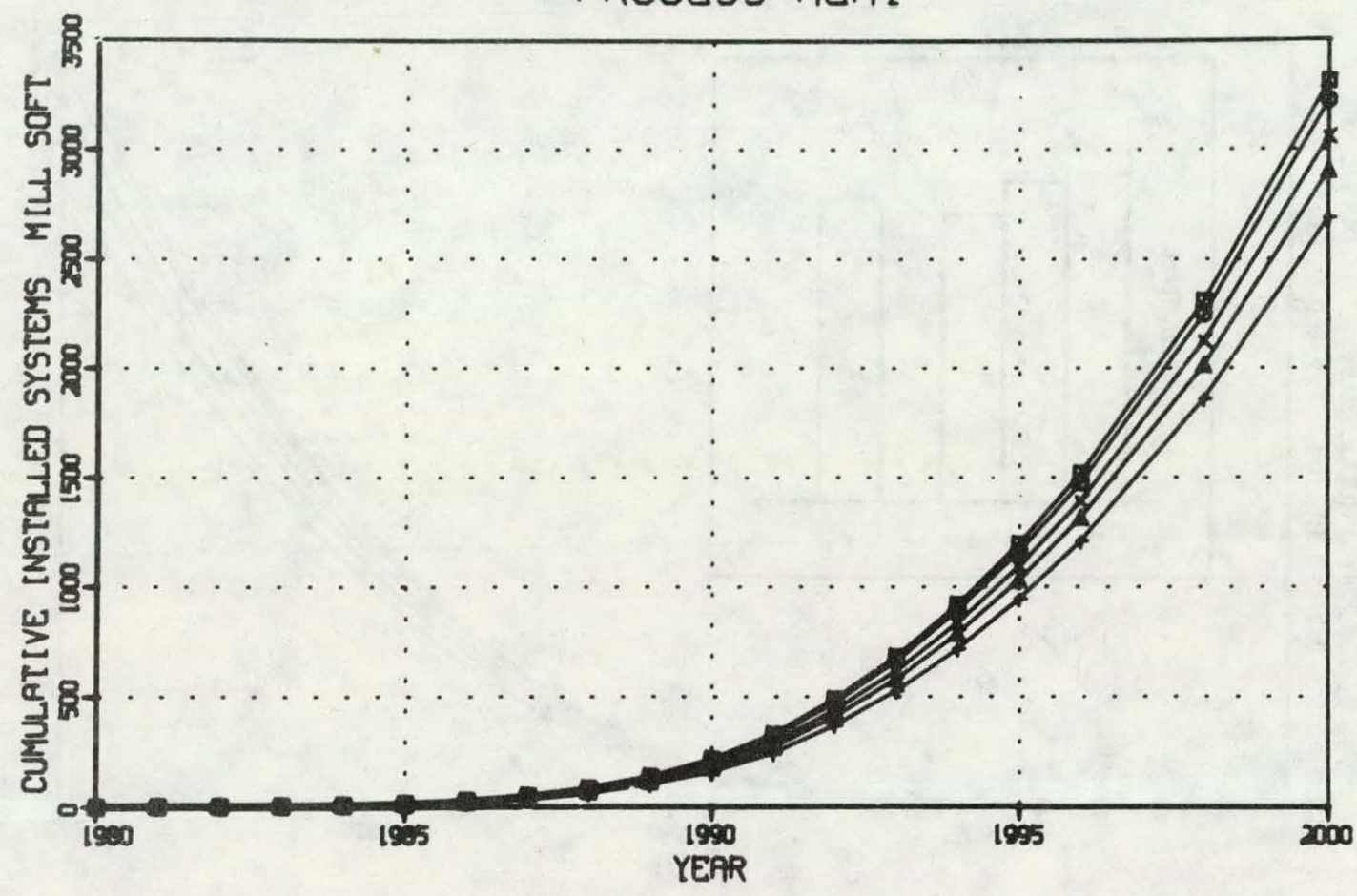

\begin{tabular}{|c|c|c|c|}
\hline \multirow{5}{*}{ 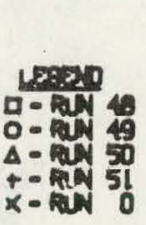 } & Run & Change & in o\&n Costs \\
\hline & 48. & & -30 \\
\hline & 49 & & -20 \\
\hline & 50 & & +20 \\
\hline & 51 & & +50 \\
\hline & 0 & & Baseline \\
\hline
\end{tabular}

Figure 4-1. Process Heat, \% O\&M Costs Change vs. Cumulative Installed Systems 


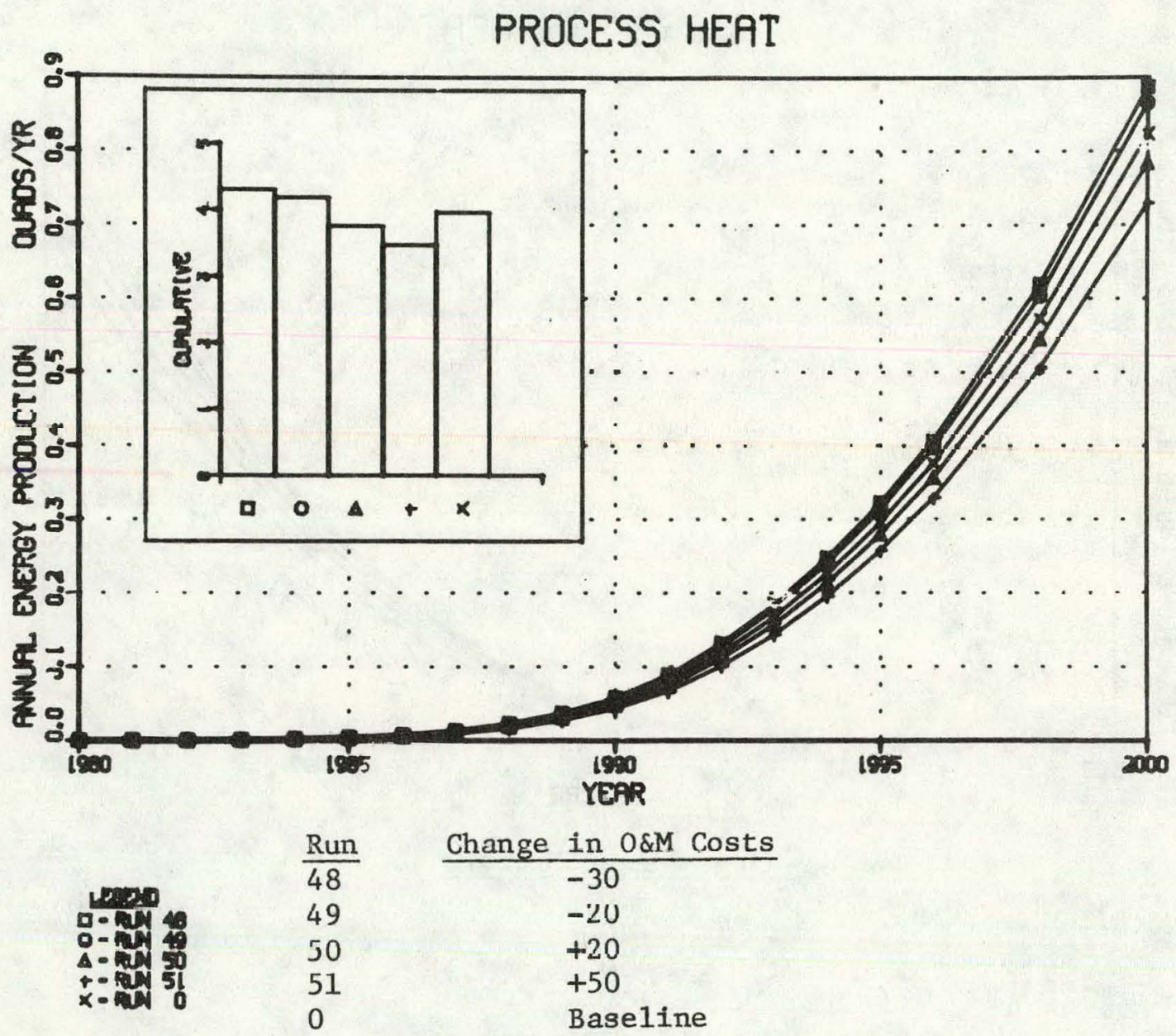

Figure 4-2. Process Heat, \% O\&M Costs Change vs. Annual Energy Production 
PROCESS HEAT

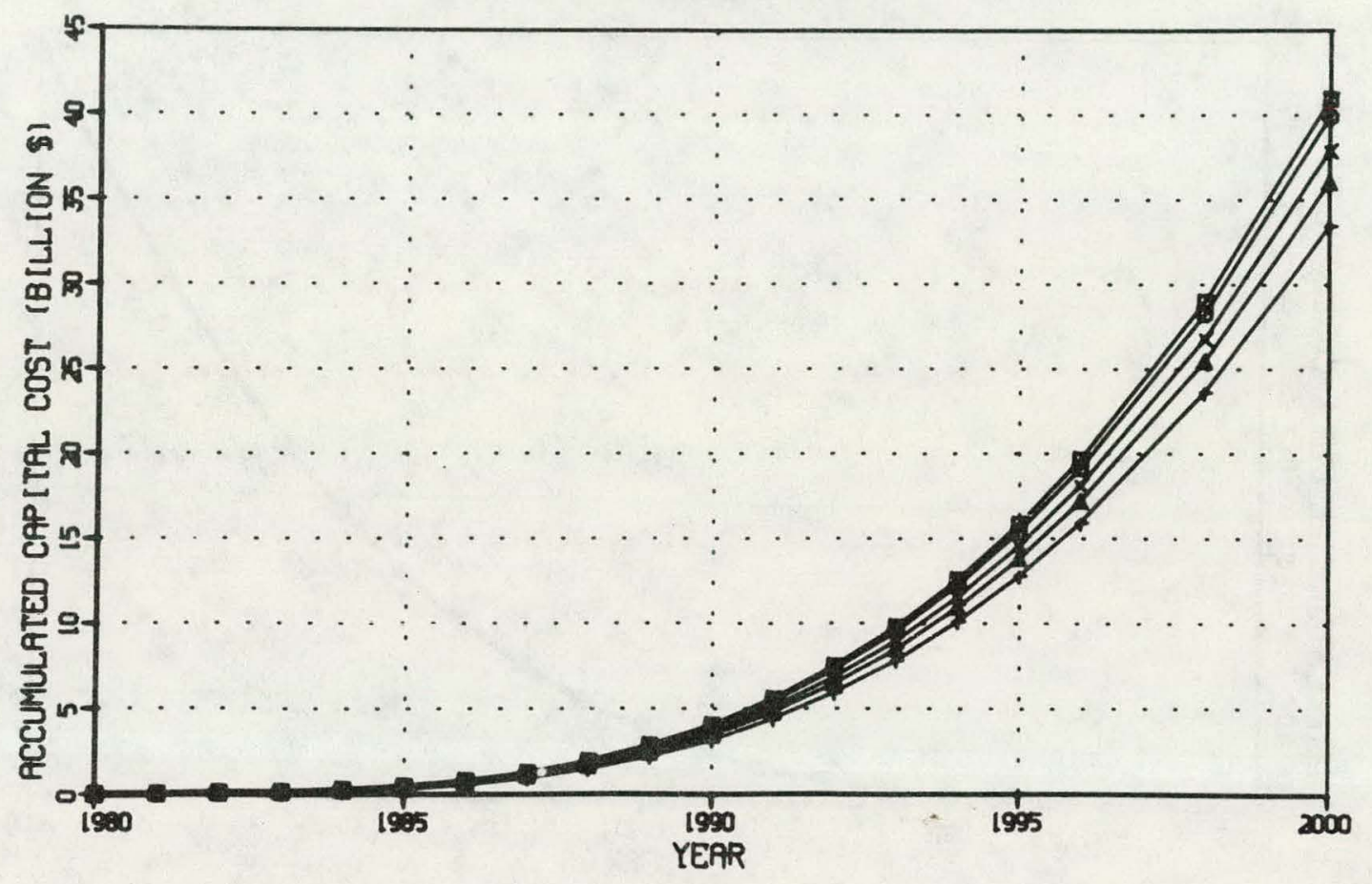

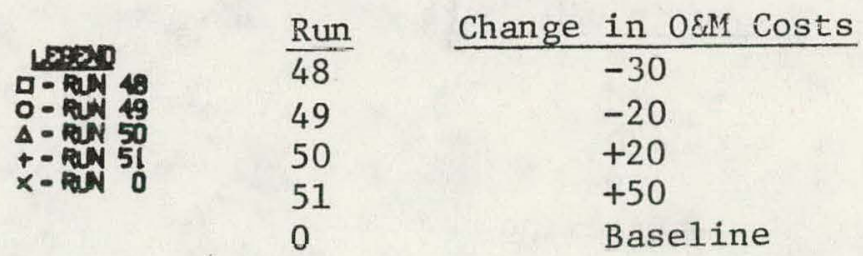

Figure 4-3. Process Heat, \% O\&M Costs Change vs. Accumulated Capital Costs 


\section{PROCESS HEAT}

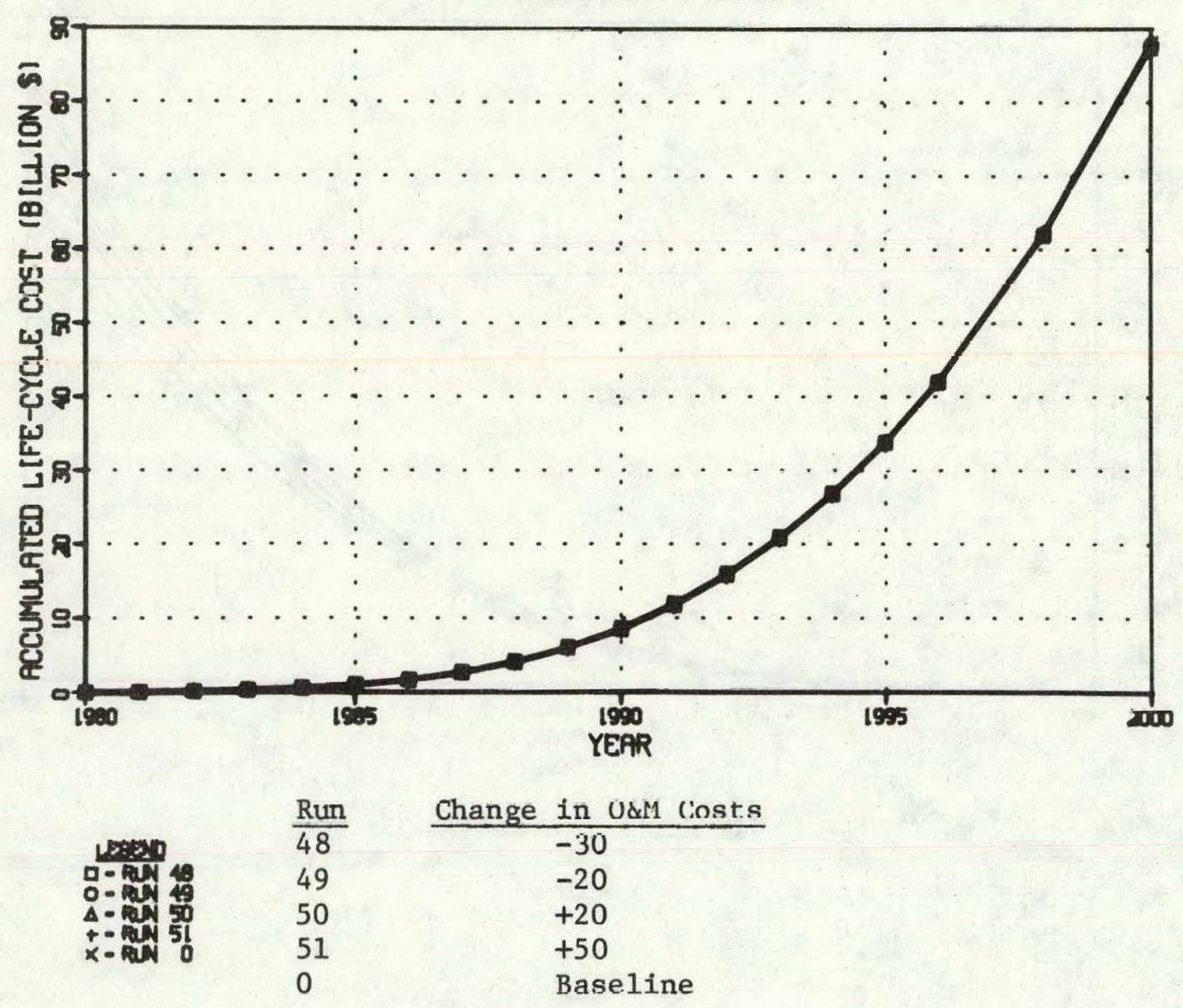

Figure 4-4. Process Heat, \% O\&M Costs Changé vs. Accumulated Life-Cycle Costs 


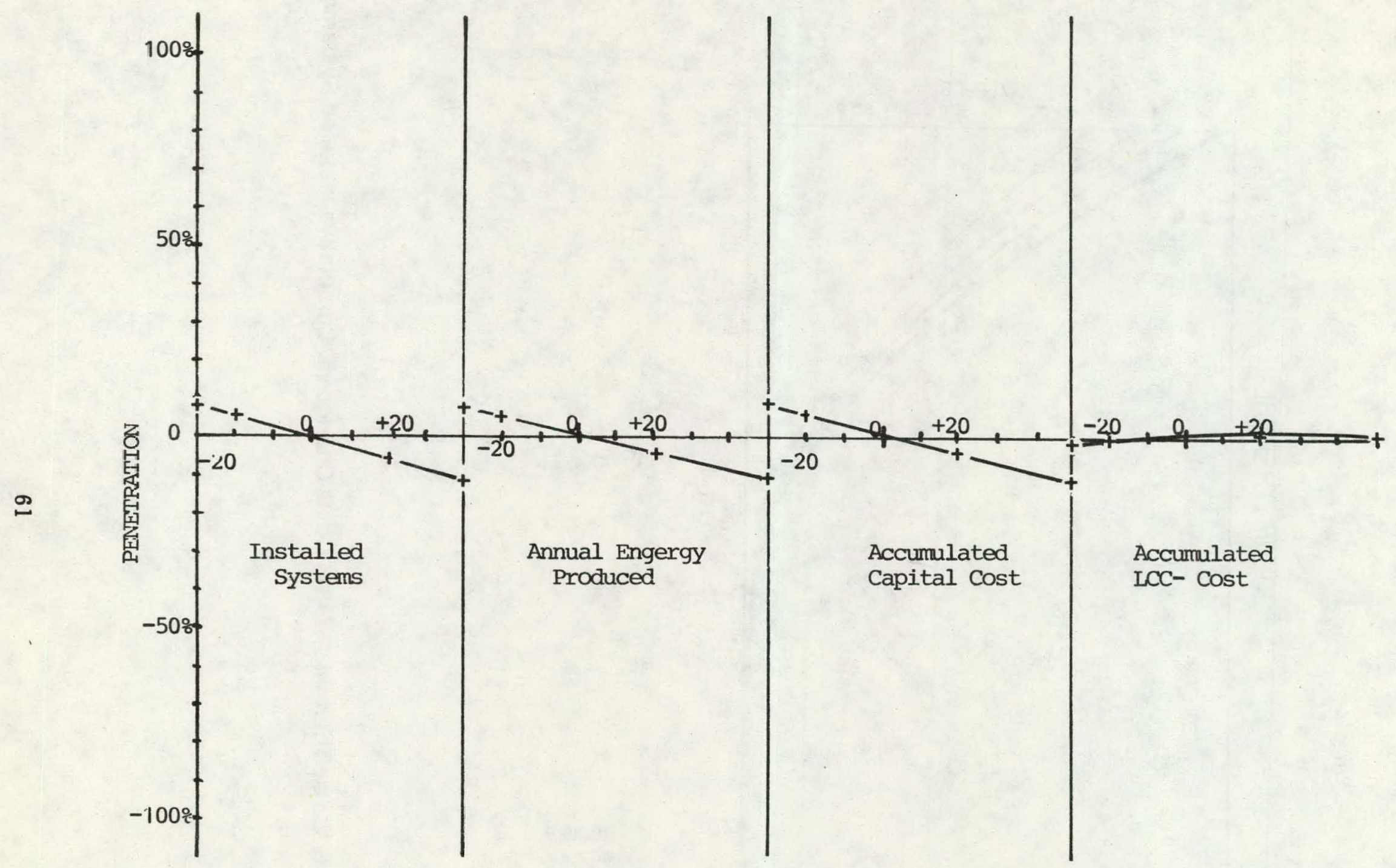

Figure 4-5. \% Change in Process Heat Variables vs. Change in System O\&M Cosț for Year 2000 
SOLAR THERMAL



Figure 4-6. Solar Thermal, \% O\&M Costs Change vs. Cumulative Installed Systems 
SOLAR THERMAL

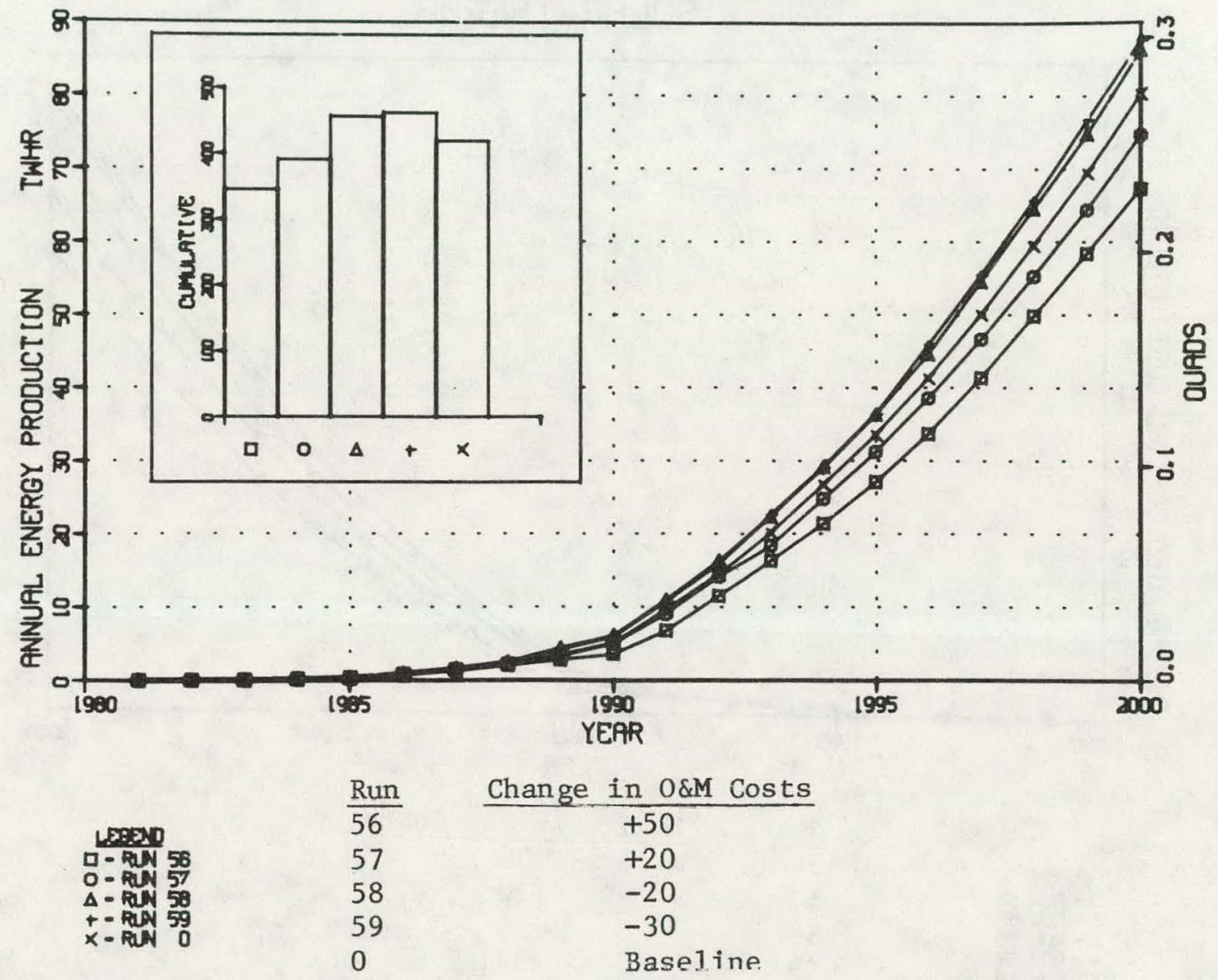

Figure 4-7. Solar Thermal, \% O\&M Costs Change vs. Annual Energy Production 
SOLAR THERMAL

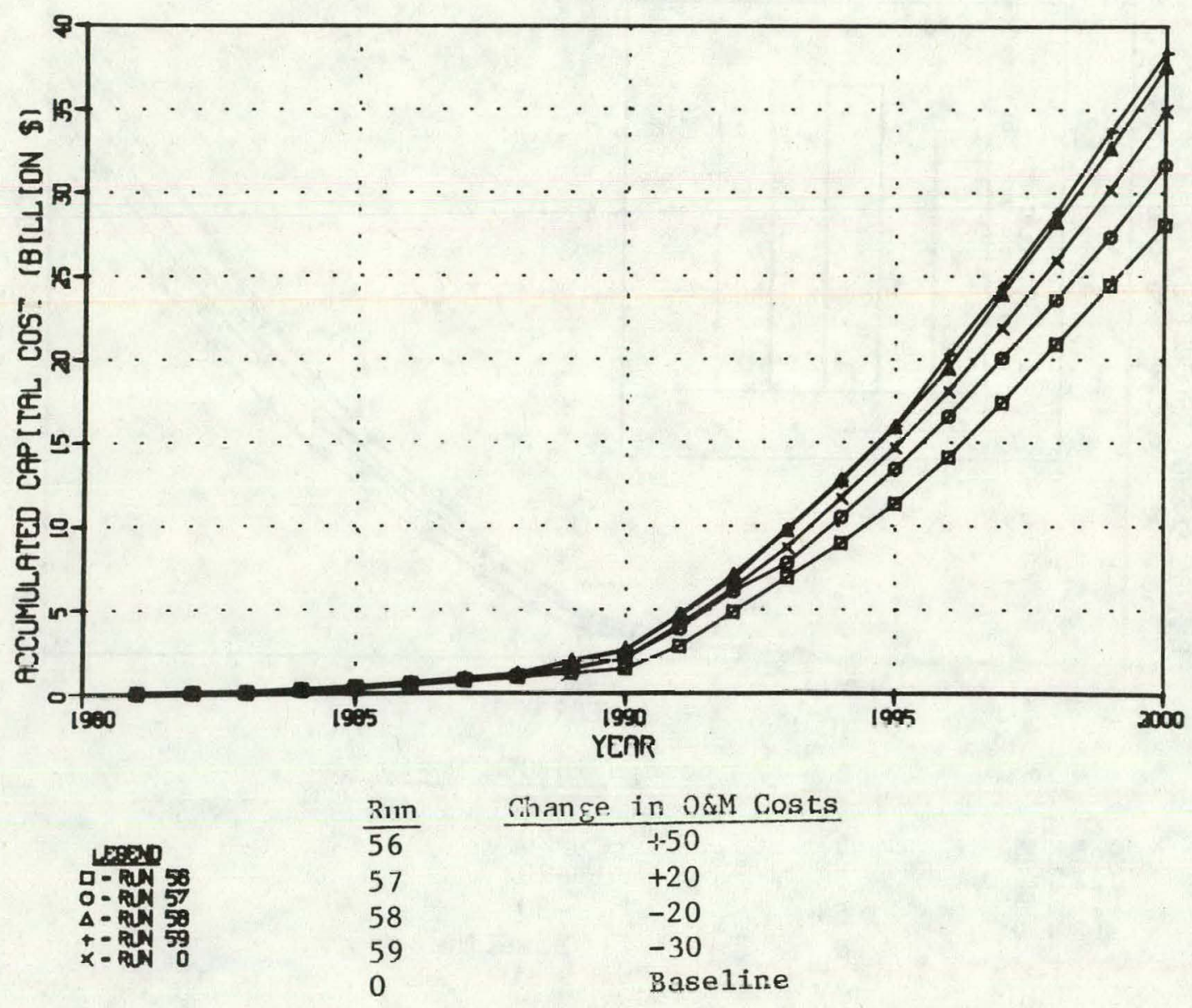

Figure 4-8. Solar Thermal, \% O\&M Costs Change vs. Accumulated Capital Costs 
SOLAR THERMAL

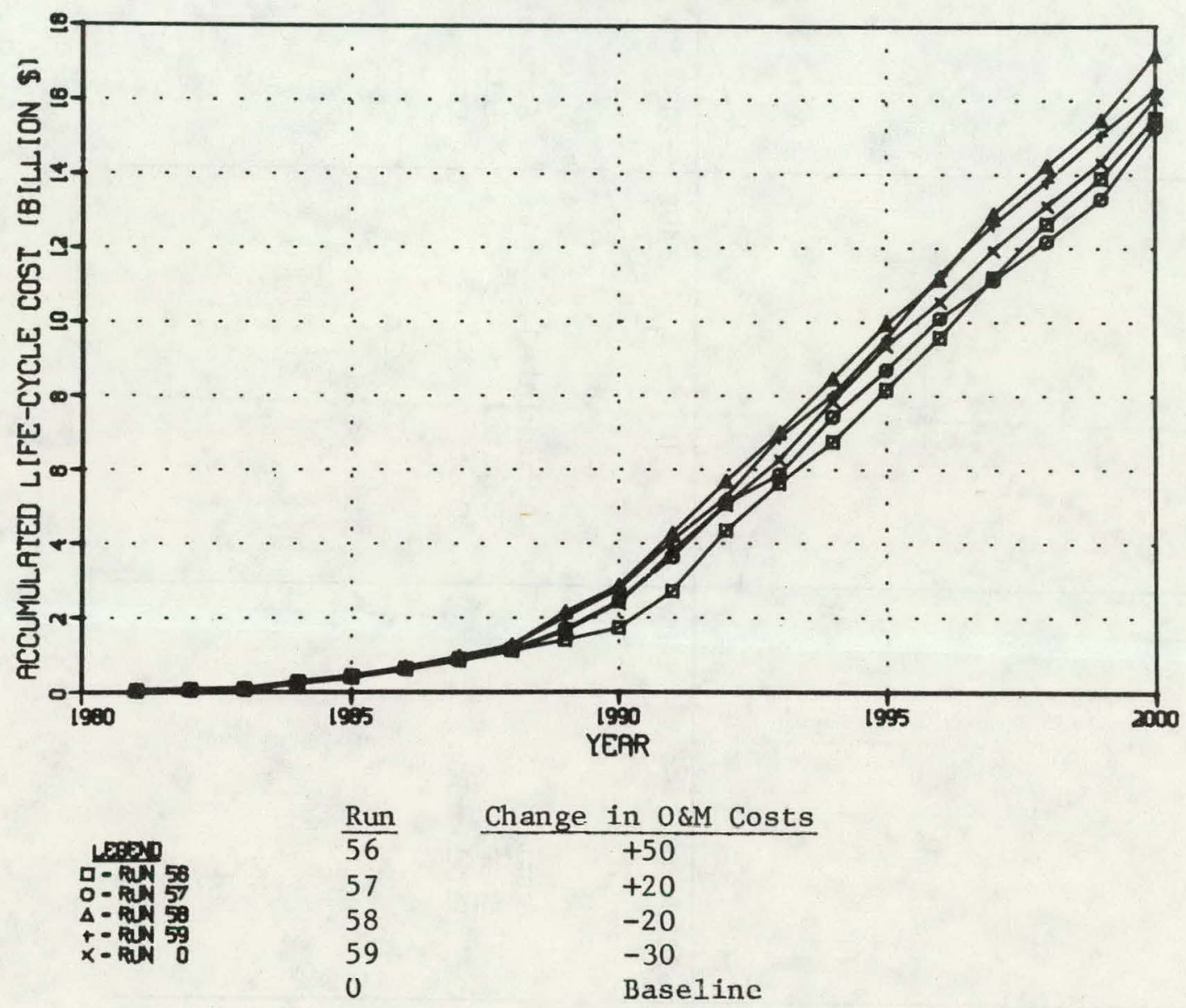

Figure 4-9. Solar Thermal, \% O\&M Costs Change vs. Accumulated Life-Cycle Costs 


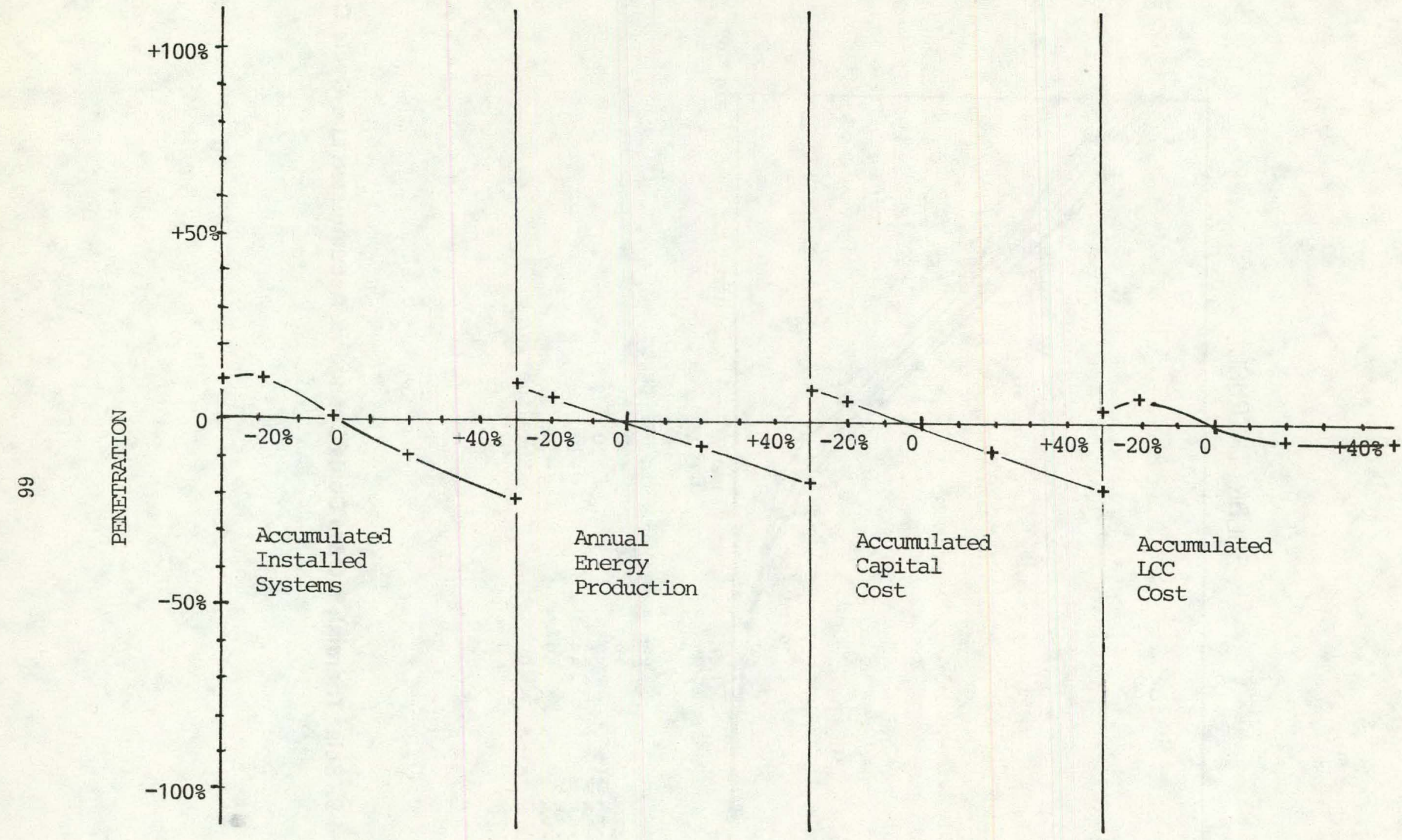

Figure 4-10. \% Change in Solar Thermal Utility Variables vs. $\%$ Change in System Annual O\&M for Year 2000 


\begin{tabular}{|c|c|c|c|c|}
\hline & $\begin{array}{c}\text { Acc. } \\
\text { Installed } \\
\text { Systems } \\
\end{array}$ & $\begin{array}{c}\text { Annual } \\
\text { Energy } \\
\text { Produced } \\
\end{array}$ & $\begin{array}{c}\text { Acc. } \\
\text { Capital } \\
\text { Cost }\end{array}$ & $\begin{array}{l}\text { Acc. } \\
\text { LCC } \\
\text { Cost } \\
\end{array}$ \\
\hline $\begin{array}{l}\text { Type of } \\
\text { relationship }\end{array}$ & $\begin{array}{l}\text { Linear, } \\
\text { inverse }\end{array}$ & $\begin{array}{l}\text { Linear, } \\
\text { inverse }\end{array}$ & $\begin{array}{l}\text { Linear, } \\
\text { inverse }\end{array}$ & $\begin{array}{l}\text { Linear, } \\
\text { inverse }\end{array}$ \\
\hline Sense & Proper & Proper & Proper & Proper \\
\hline Sensitivity & $\begin{array}{l}\text { Low } \\
0.3: 1\end{array}$ & $\begin{array}{l}\text { Low } \\
0.3: 1\end{array}$ & $\begin{array}{l}\text { Low } \\
0.3: 1\end{array}$ & - \\
\hline
\end{tabular}

In summary, the penetration of solar thermal utilities was relatively insensitive to changes in $O \& M$ cost.

\subsection{PHOTOVOLTAIC UTHITIES PENETRATION VS. ANNUAL O\&M COST}

The sensitivity of photovoltaic utility technologies (see Table 2-2) penetration as a function of time to variation in annual O\&M cost of $-30 \%$ to $+50 \%$ is shown in Figs. 4-11 through 4-14. Figure 4-15 shows the percentage variation in penetration of the SPURR output parameters for the year 2000. The changes in the photovoltaic utility technologies were done as a group in this analysis but could have been done individually; i.e., the changes were the same for each technology in this group as the technology entered the marketplace (see market entry dates in Table 2-1). The following is a summary of the resul ts:

\begin{tabular}{|c|c|c|c|c|}
\hline & $\begin{array}{l}\text { Acc. } \\
\text { Installed } \\
\text { Systems }\end{array}$ & $\begin{array}{c}\text { Annual } \\
\text { Energy } \\
\text { Produced } \\
\end{array}$ & $\begin{array}{c}\text { Acc. } \\
\text { Capital } \\
\text { Cost } \\
\end{array}$ & $\begin{array}{l}\text { Acc. } \\
\text { LCC } \\
\text { Cost } \\
\end{array}$ \\
\hline $\begin{array}{l}\text { Type of } \\
\text { relationship }\end{array}$ & $\begin{array}{l}\text { Linear, } \\
\text { inverse }\end{array}$ & $\begin{array}{l}\text { Linear, } \\
\text { inverse }\end{array}$ & $\begin{array}{l}\text { Linear, } \\
\text { inverse }\end{array}$ & Nonlinear \\
\hline Sense & Proper & Proper & Proper & Proper \\
\hline Sensi tivity & $\begin{array}{l}\text { Moderate } \\
1: 1\end{array}$ & $\begin{array}{l}\text { Moderate } \\
1.3: 1\end{array}$ & $\begin{array}{l}\text { Moderate } \\
1.1\end{array}$ & $\begin{array}{l}\text { Moderate } \\
2: 1\end{array}$ \\
\hline
\end{tabular}

The penetration of photovoltaic utilities is sensitive to O\&M cost and the effect is linear. In the penetration variables plotted, the effect is inverse (see Fig. 4-15) with the exception of accumulated life-cycle cost. In this case, the sensitivity to $O \& M$ is enough to reduce the accumulated life-cycle cost when O\&M is reduced. In solar thermal utilities the sensitivity to O\&M was not enough to show a reduction in accumulated life-cycle cost with reduced $O \& M$ cost. The nonlinear relationship (see Fig. 4-14) of accumulated life-cycle cost is due to the inclusion of photovoltaic fuel-saver systems in this group (as discussed in Section 3.0). 


\section{PHOTOVOLTAICS}

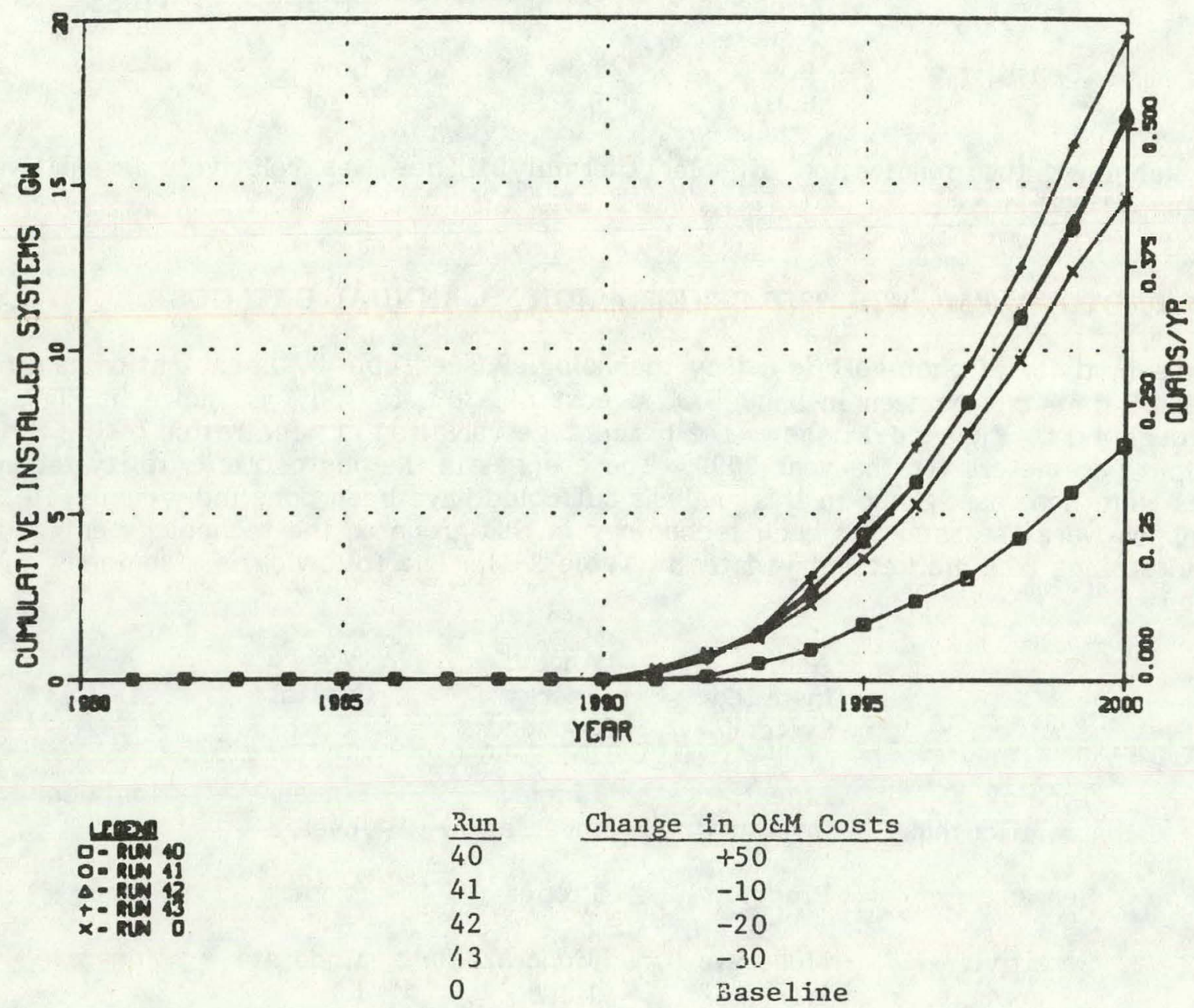

Figure 4-11. Photovoltaics, $\%$ O\&M Costs Change vs. Cumulative Installed Systems 


\section{PHOTOVOLTAICS}

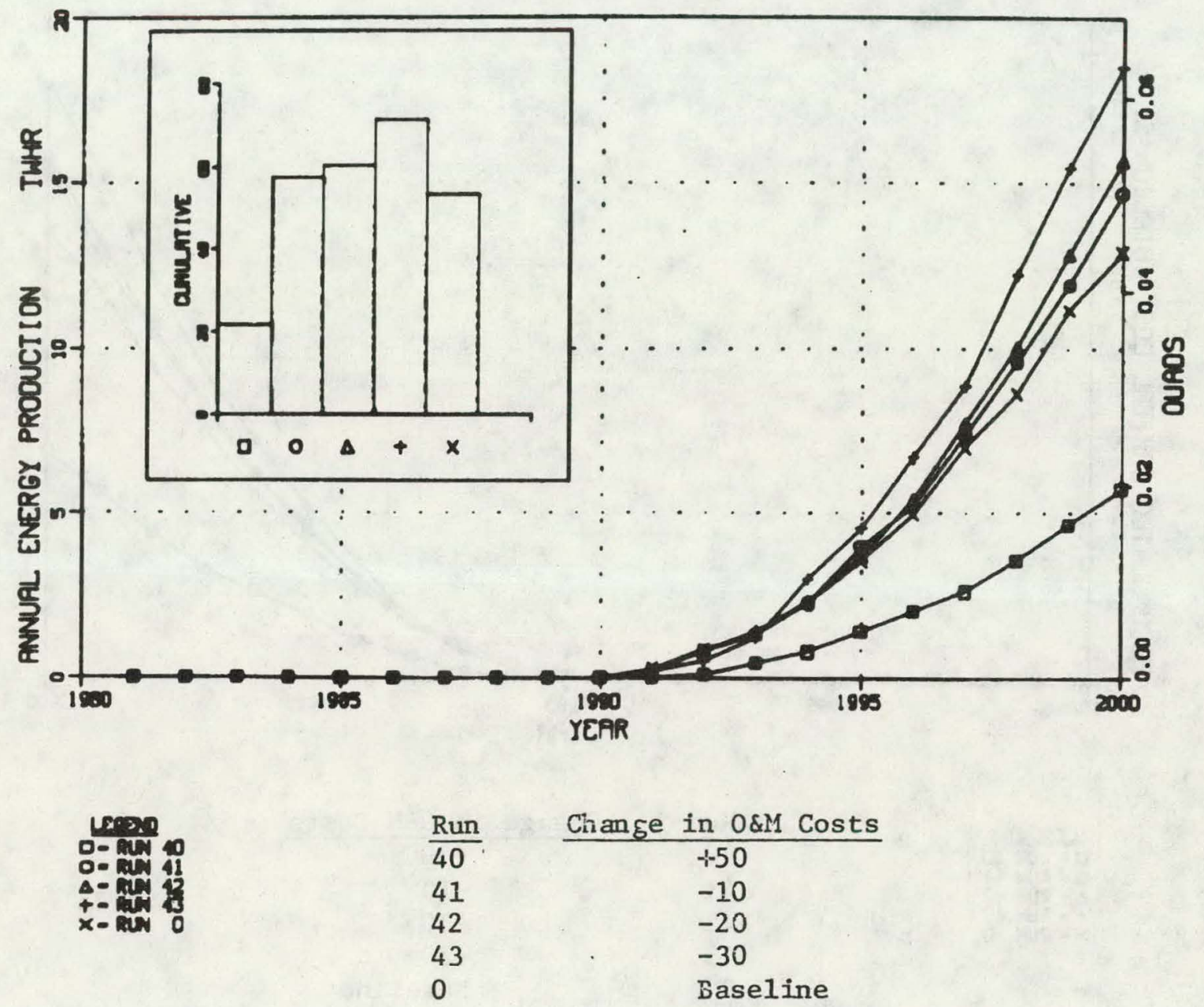

Figure 4-12. Photovoltaics, \% O\&M Costs Change vs. Annual Energy Production 
PHOTOVOLTAICS
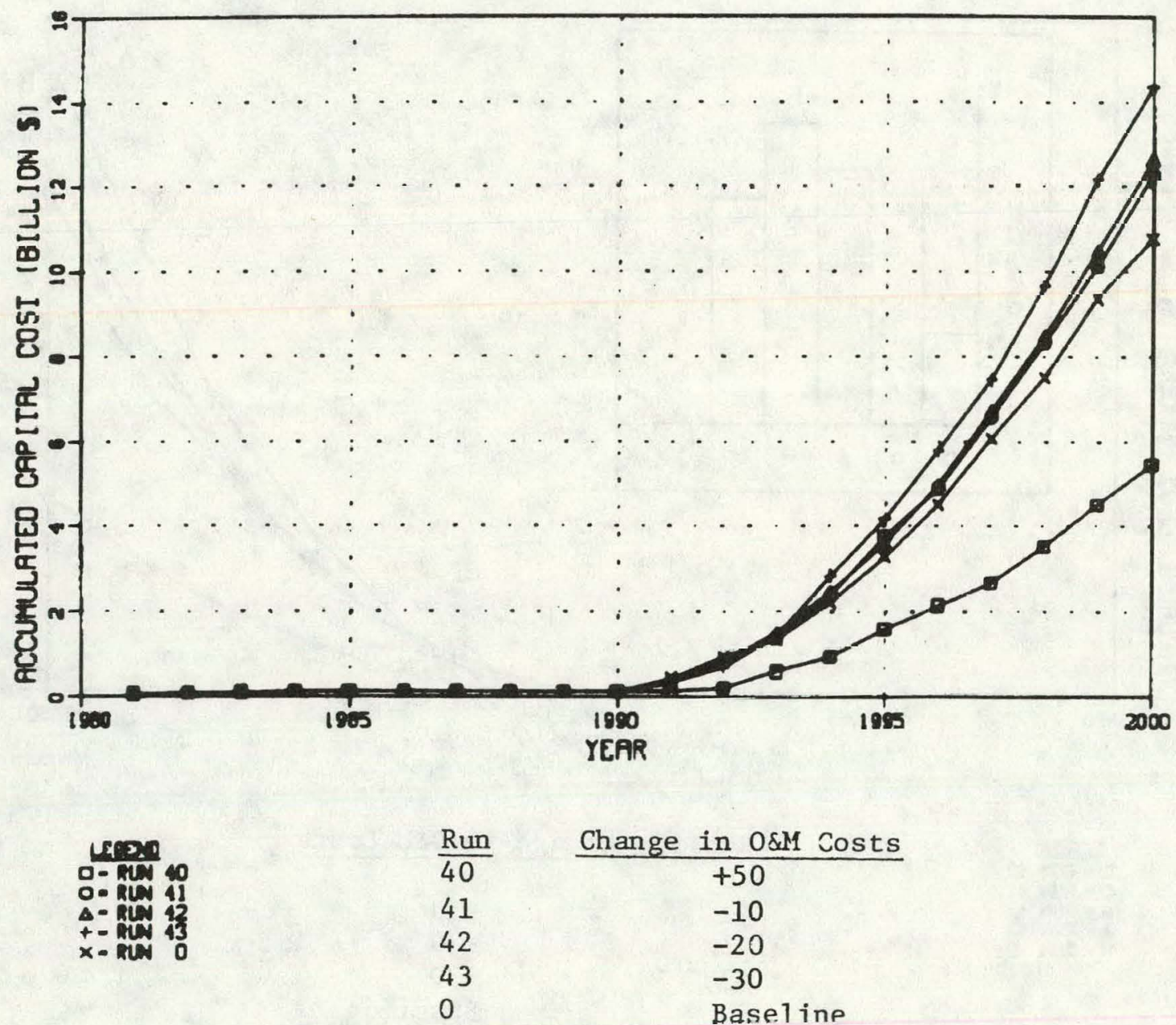

Figure 4-13. Photovoltaics, $\%$ O\&M Costs Change vs.Accumulated Capital Costs 

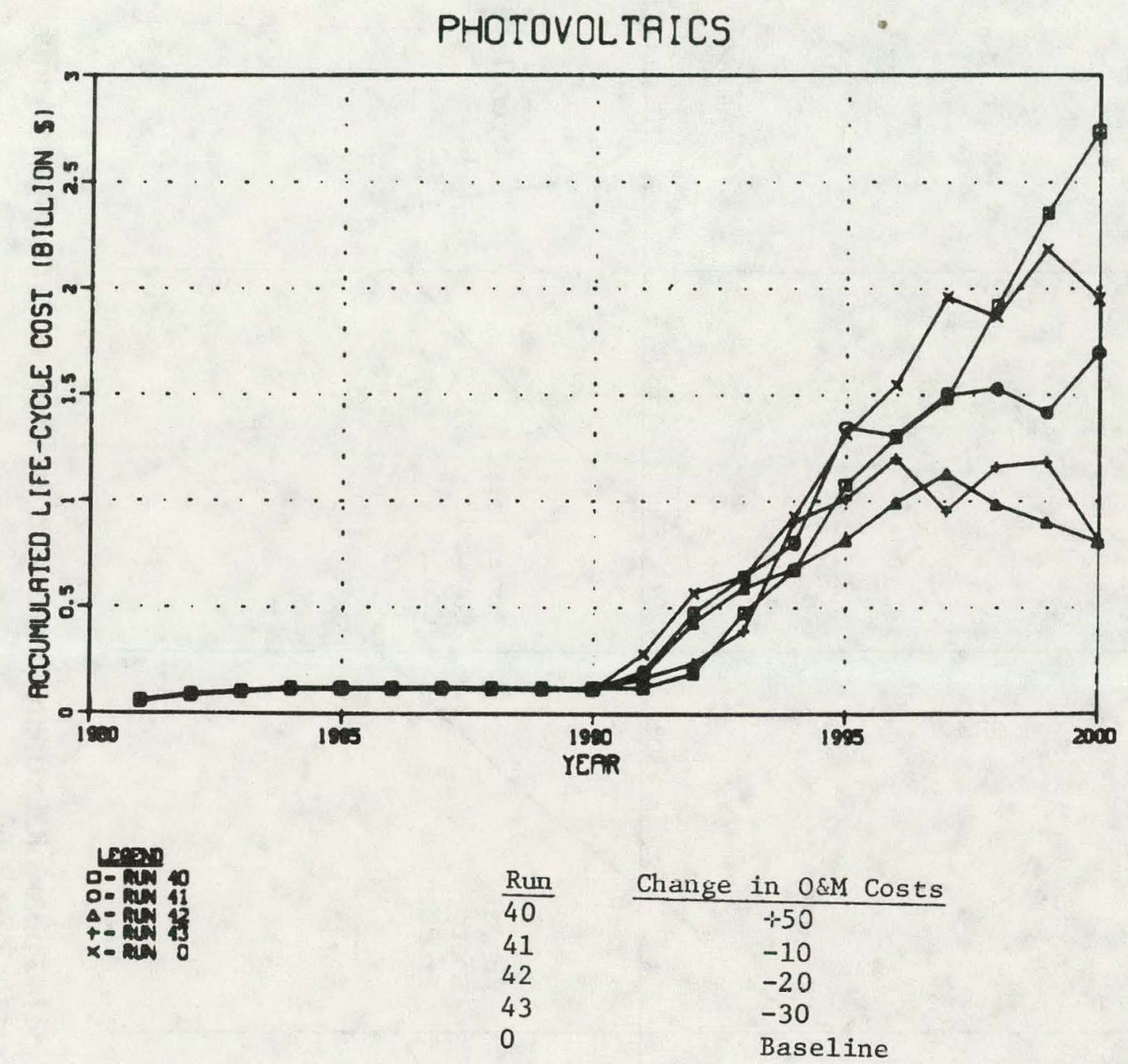

Figure 4-14. Photovoltaics, $\%$ O\&M Costs Change vs. Accumulated Life-Cycle Costs 


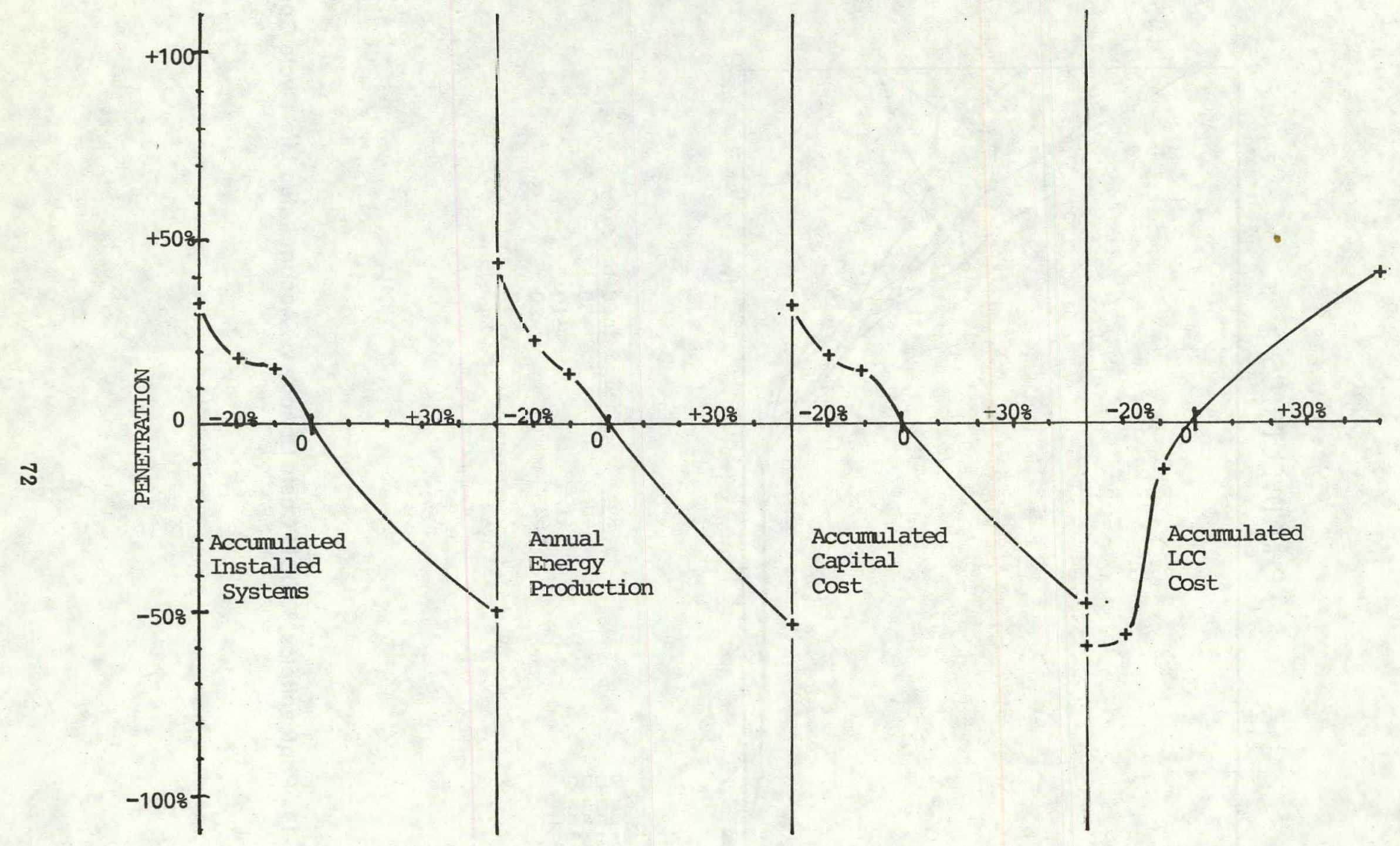

Figure 4-15. \% Change in Photovoltaic Utility Penetration Variables vs. $\%$ Change in Annual O\&M Cost for Year 2000 


\subsection{BIOMASS SYSTEMS* PENETRATION VS. ANNUAL O\&M COST}

The sensitivity of biomass systems* technologies (see Table 2-2) penetration as a function of time to variation in annual O\&M cost of $-30 \%$ to $+30 \%$ is shown in Figs. $4-16$ through 4-19. Figure 4-20 shows the percentage variation in penetration of the SPURR output parameters for the year 2000. The changes in the biomass system technologies were done as a group, but they could have been done individually; i.e., the changes were the same for each technology in this group as the technology entered the marketplace (see market entry dates in Table 2-1). The following is a summary of the results:

$\begin{array}{lllll} & \begin{array}{c}\text { Acc. } \\ \text { Installed } \\ \text { Systems }\end{array} & \begin{array}{c}\text { Annual } \\ \text { Energy } \\ \text { Produced }\end{array} & \begin{array}{c}\text { Acc. } \\ \text { Capital } \\ \text { Cost }\end{array} & \begin{array}{c}\text { Acc. } \\ \text { Type of } \\ \text { relationship }\end{array} \\ \begin{array}{lllll}\text { Linear, } \\ \text { Sense }\end{array} & \begin{array}{l}\text { Linear, } \\ \text { inverse }\end{array} & \begin{array}{c}\text { Linear, } \\ \text { inverse }\end{array} & \begin{array}{c}\text { Linear, } \\ \text { inverse }\end{array} \\ \text { Sensitivity } & \text { Proper } & \text { Proper } & \text { Proper } & \text { Proper } \\ & \text { Low } & \text { Low } & \text { Low } & \text { Low } \\ & 0.3: 1 & 0.3: 1 & 0.3: 1 & 0.3: 1\end{array}$

The biomass system technologies are relatively insensitive to changes in O\&M. The dominant factor in biomass cost are capital and fuel costs.

\subsection{WECS UTILITY PENETRATION VS. ANNUAL O\&M COST}

The sensitivity of WECS utility technology (see Table 2-2) penetration as a function of time to variation in annual O\&M cost of $-30 \%$ to $+50 \%$ is shown in Figs. $4-21$ through 4-25. Figure 4-26 shows the percentage variation in penetration of the SPURR output parameters for the year 2000. In addition to the standard four variables plotted as a function of time, annual fuel utilization was plotted also to show the fuel savings by WECS. The changes in the WECS utility technologies were done as a group in this analysis but could have been done individually; i.e., the changes were the same for each technology in this group as the technology entered the marketplace (see market entry dates in Table 2-1). The following is a summary of the results:

\begin{tabular}{|c|c|c|c|c|}
\hline & $\begin{array}{c}\text { Acc. } \\
\text { Installed } \\
\text { Systems }\end{array}$ & $\begin{array}{c}\text { Annual } \\
\text { Energy } \\
\text { Produced } \\
\end{array}$ & $\begin{array}{c}\text { Acc. } \\
\text { Capital } \\
\text { Cost }\end{array}$ & $\begin{array}{l}\text { Acc. } \\
\text { LCC } \\
\text { Cost } \\
\end{array}$ \\
\hline $\begin{array}{l}\text { Type of } \\
\text { relationship }\end{array}$ & $\begin{array}{l}\text { Linear, } \\
\text { inverse }\end{array}$ & $\begin{array}{l}\text { Linear, } \\
\text { inverse }\end{array}$ & $\begin{array}{l}\text { Linear, } \\
\text { inverse }\end{array}$ & Nonlinear \\
\hline Sense & Proper & Proper & Proper & Proper \\
\hline Sensitivity & $\begin{array}{l}\text { Low } \\
0.4: 1\end{array}$ & $\begin{array}{l}\text { Low } \\
0.5: 1\end{array}$ & $\begin{array}{l}\text { Low } \\
0.4: 1\end{array}$ & $\begin{array}{l}\text { Low } \\
0.2: 1\end{array}$ \\
\hline
\end{tabular}

*Includes utility and synthetic products technologies (see Table 2-2). 


\section{BIOMASS}

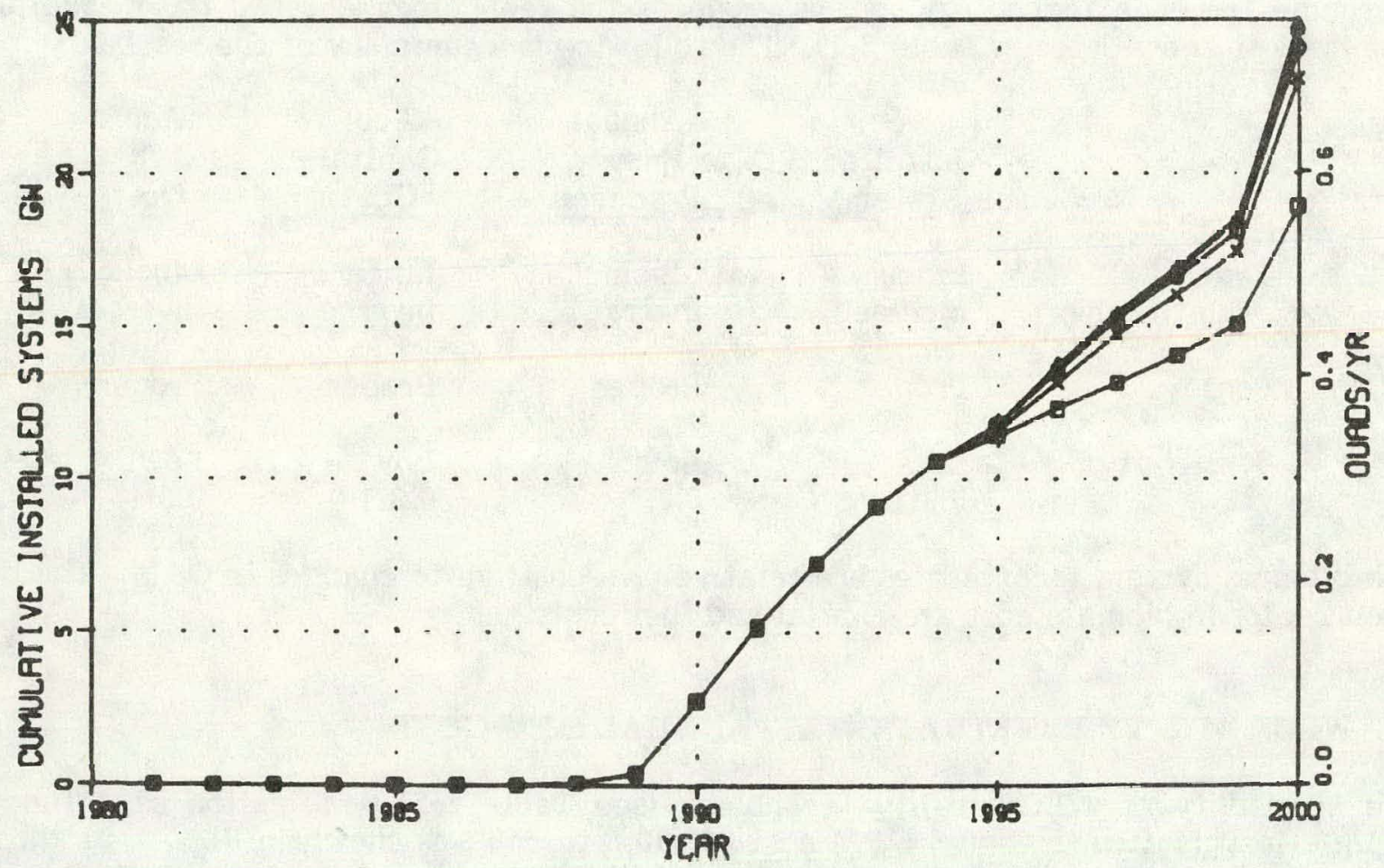

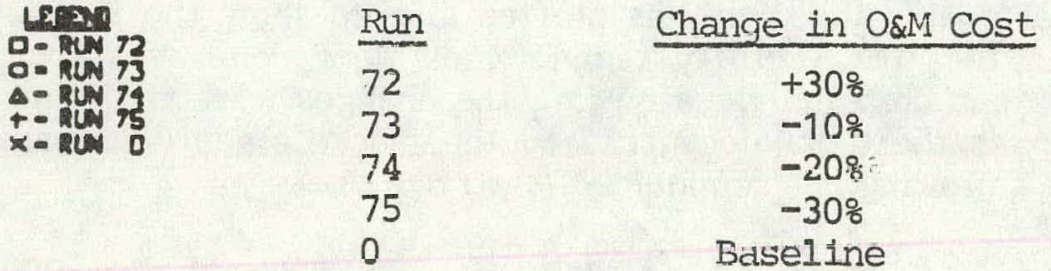

Figure 4-16. Biomass, \% O\&M Costs Change vs. Cumulative Installed Systems 


\section{BIOMASS}

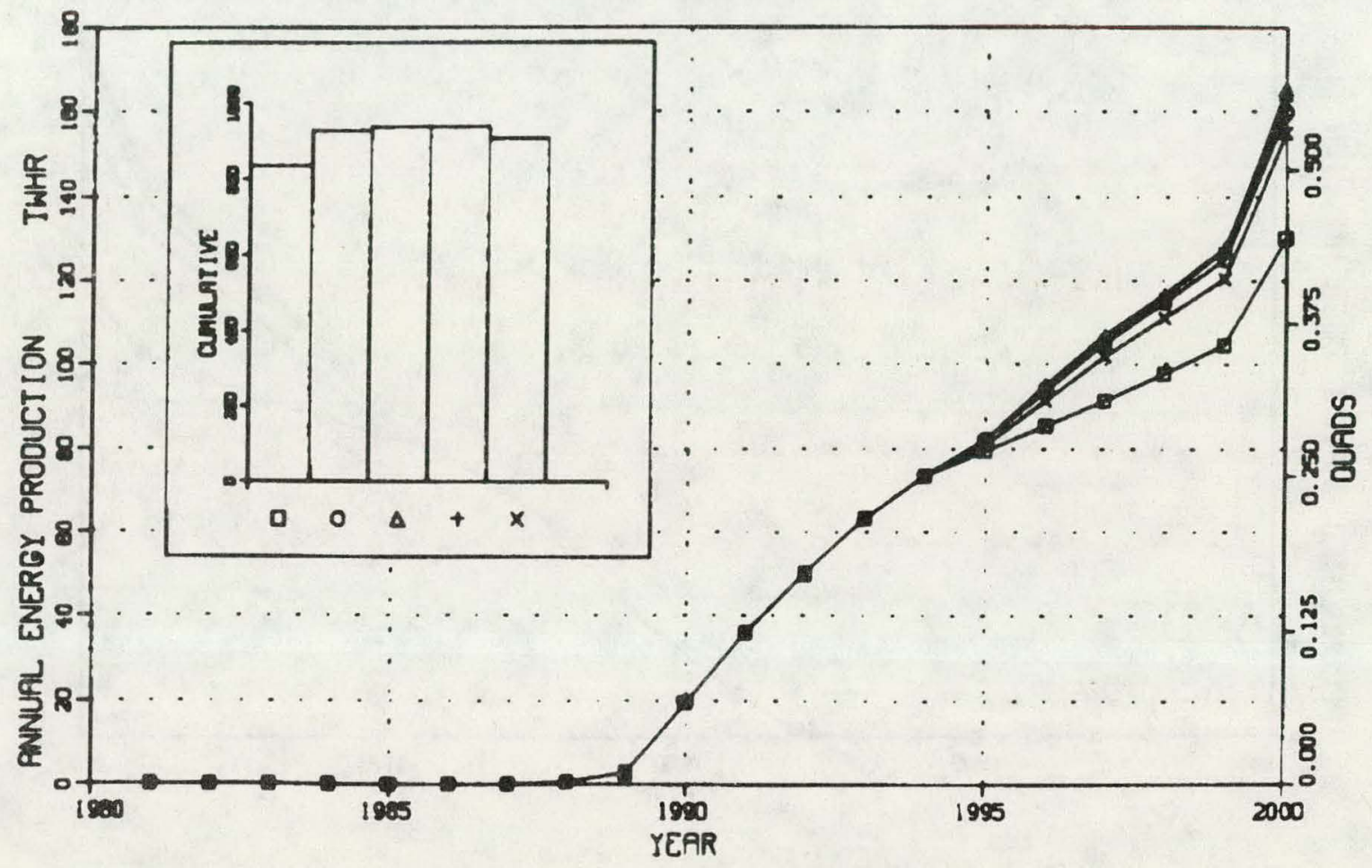

\begin{tabular}{|c|c|c|}
\hline 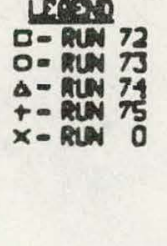 & $\begin{array}{l}\text { Run } \\
72 \\
73 \\
74 \\
75 \\
0\end{array}$ & $\begin{array}{c}\text { Change in O\&M Cost } \\
+30 \% \\
-10 \% \\
-20 \% \\
-30 \% \\
\text { Baseline }\end{array}$ \\
\hline
\end{tabular}

Figure 4-17. Biomass, \% O\&M Costs Change vs. Annual Energy Production 


\section{BIOMASS}

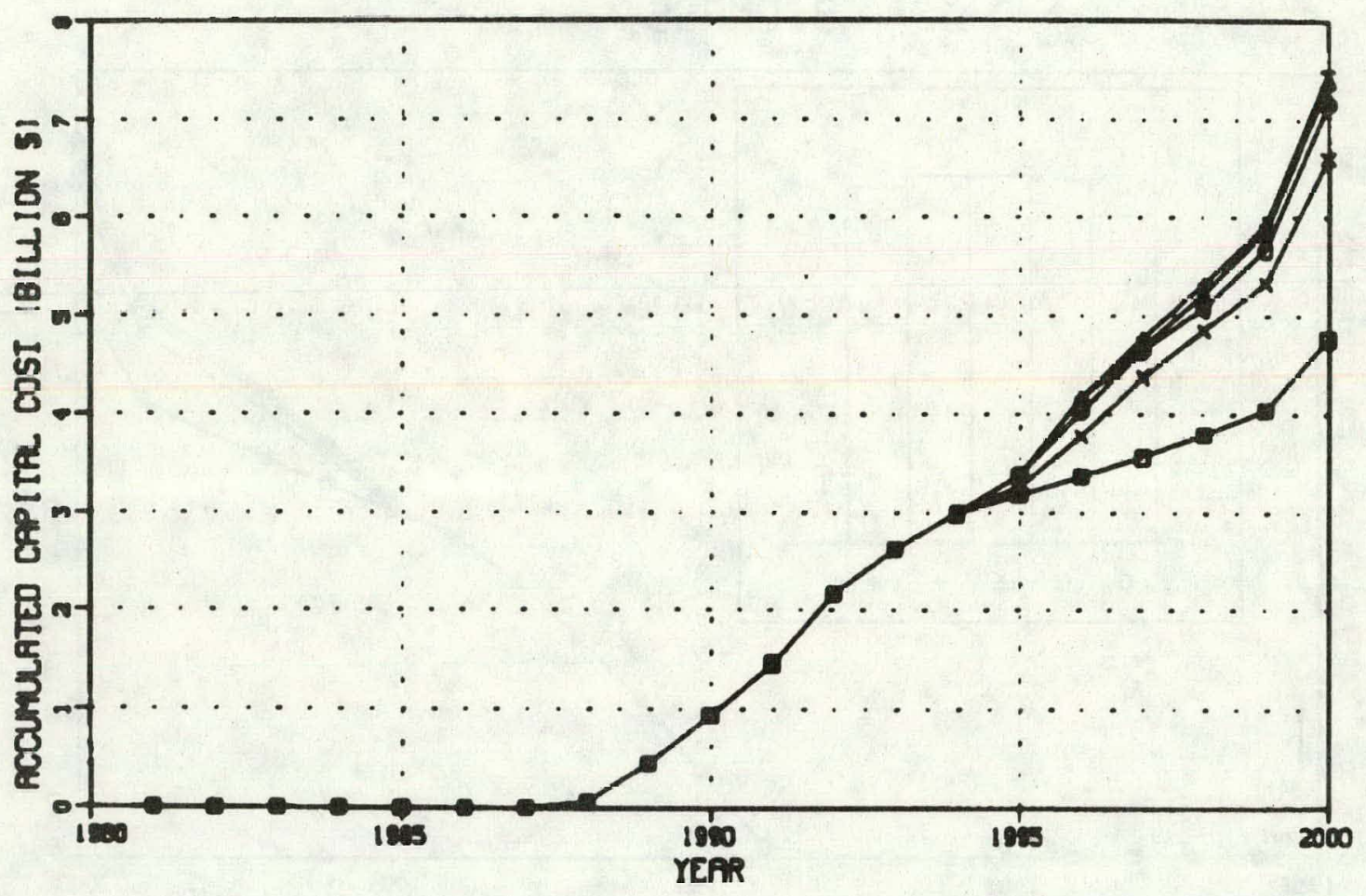

\begin{tabular}{|c|c|c|}
\hline $\operatorname{leg}_{0-\operatorname{lin}} 72$ & Run & Chenge in O\&M cost \\
\hline 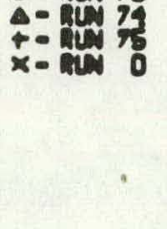 & $\begin{array}{l}72 \\
73 \\
74 \\
75 \\
0\end{array}$ & $\begin{array}{c}+30 \% \\
-10 \% \\
=20 \% \\
-30 \% \\
\text { Baseline }\end{array}$ \\
\hline
\end{tabular}

Figure 4-18. Biomass, \% O\&M Costs Change vs. Accumulated Capital Costs 


\section{BIOMASS}

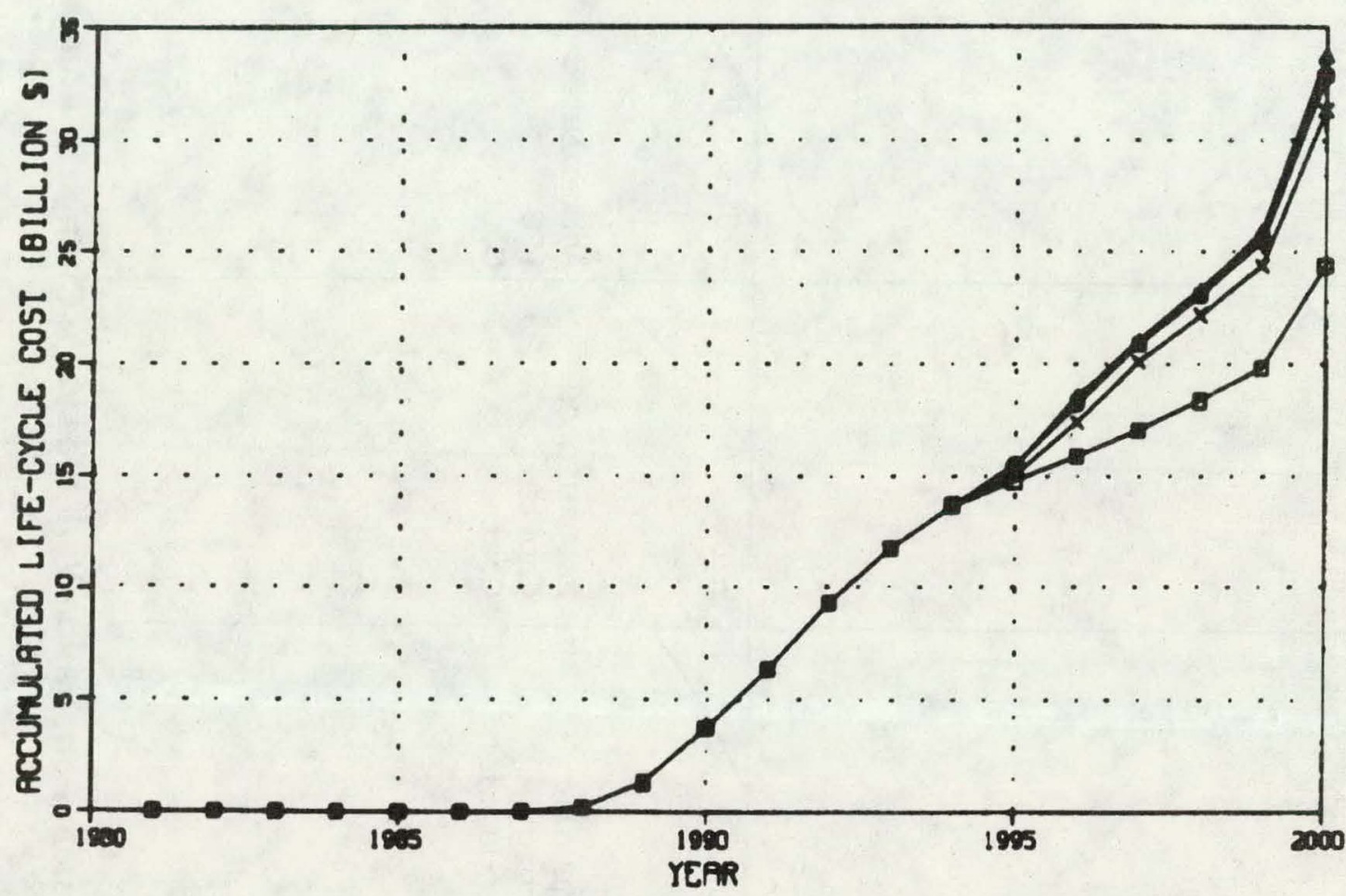

\begin{tabular}{|c|c|c|}
\hline 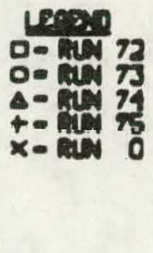 & $\begin{array}{l}\frac{\text { Run }}{72} \\
73 \\
74 \\
75 \\
0\end{array}$ & $\begin{array}{c}\text { Change in O\&M Cost } \\
+30 \% \\
-10 \% \\
-20 \% \\
-30 \% \\
\text { Baseline }\end{array}$ \\
\hline
\end{tabular}

Figure 4-19. Biomass, \% O\&M Costs Change vs. Accumulated Life-Cycle Costs 


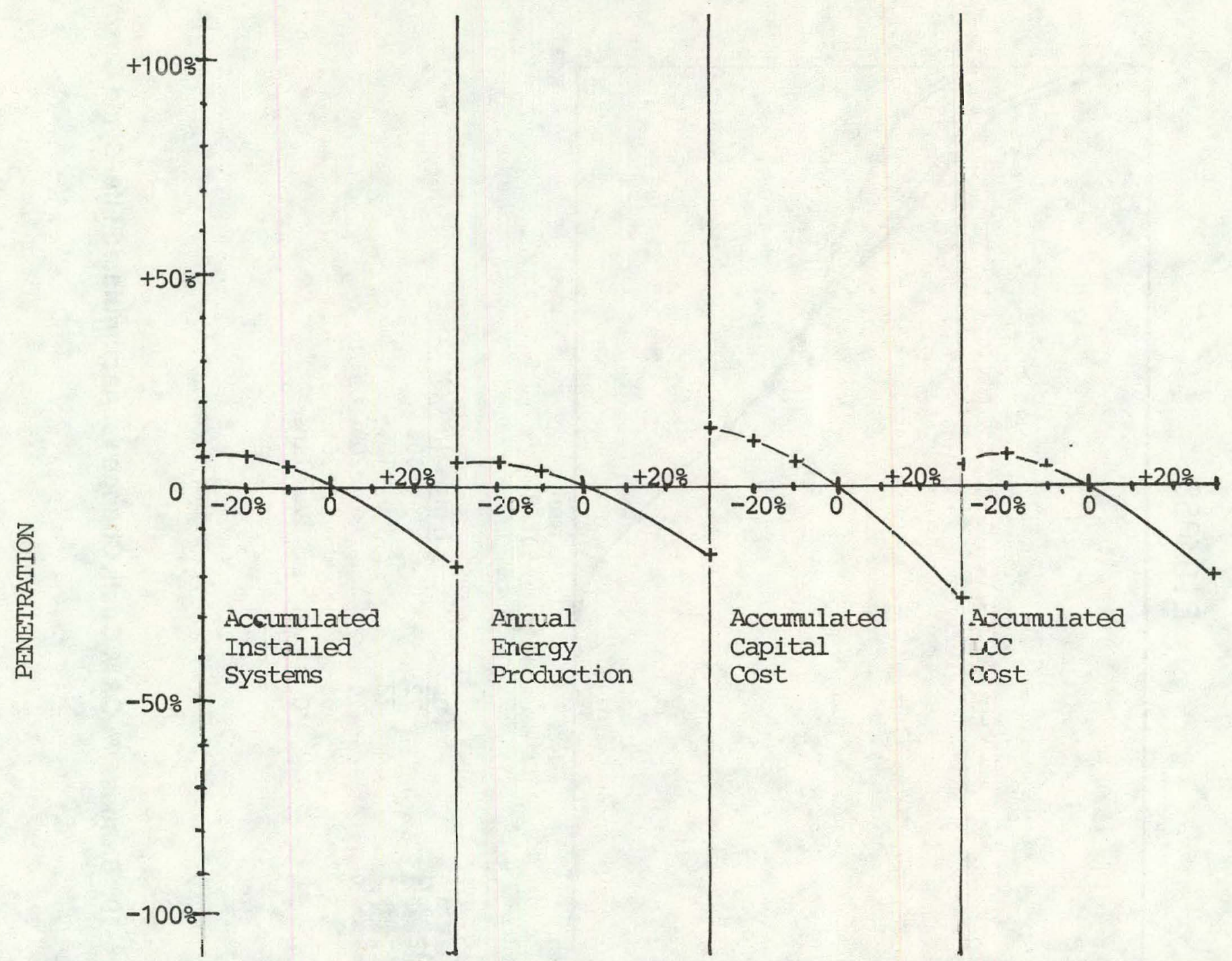

Figure 4-20. \% Change in Biomass System Penetration Variables vs. $\%$ Change in Annual O\&M Cost for Year 2000 


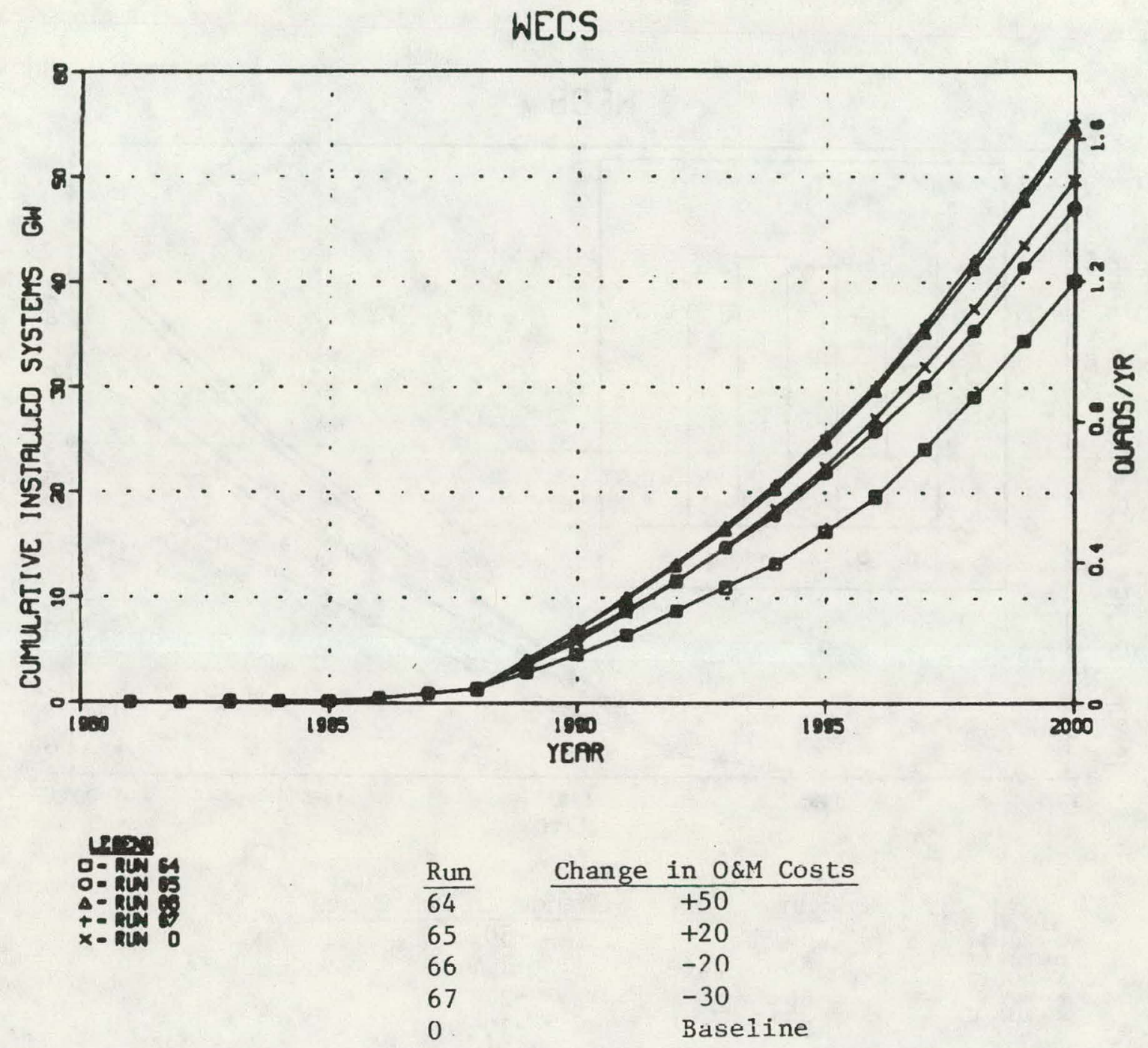

Figure 4-21. WECS, \% O\&M Costs Change vs. Cumulative Installed Systems 


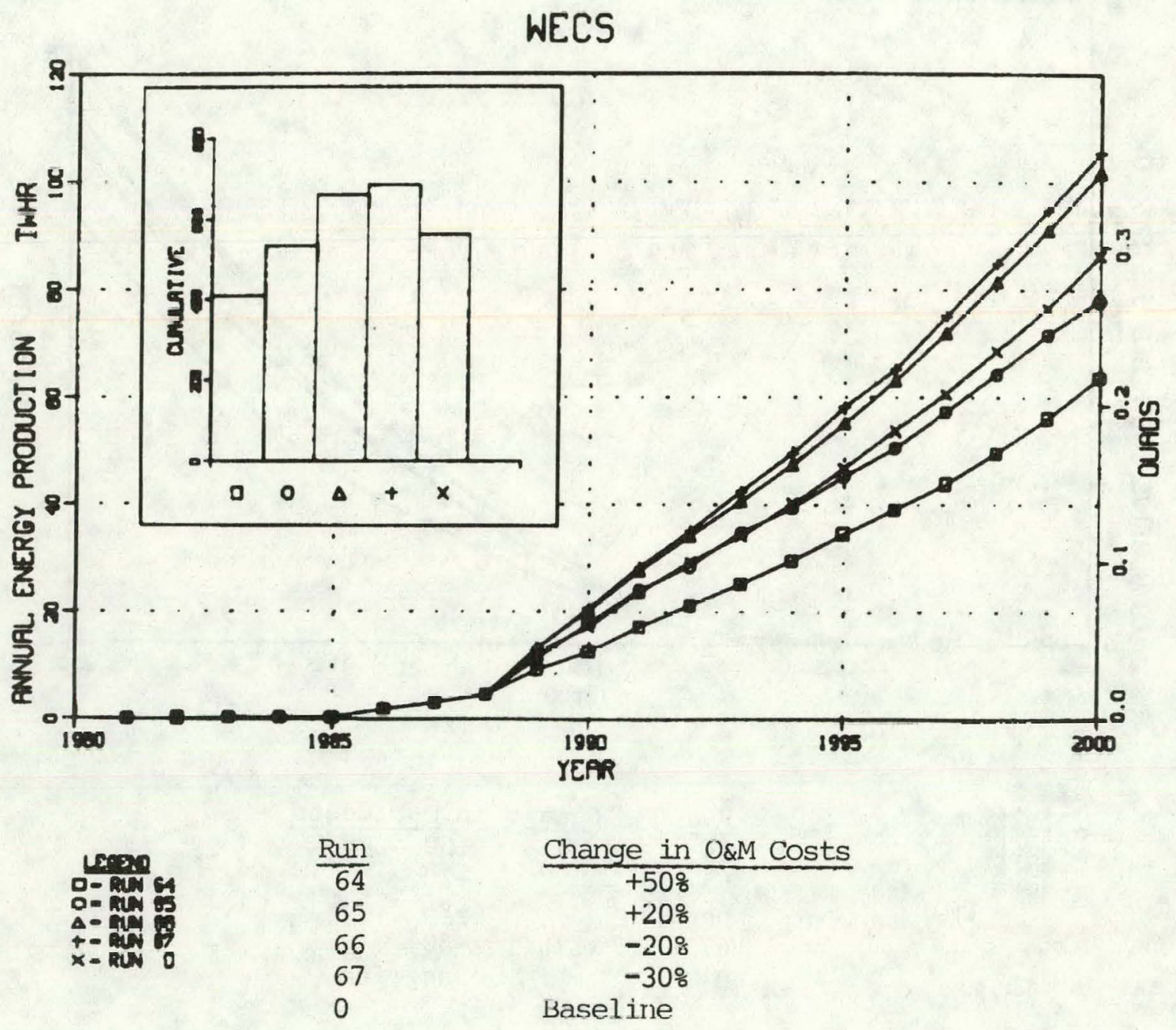

Figure 4-22. WECS, \% O\&M Costs Change vs. Annual Energy Production 


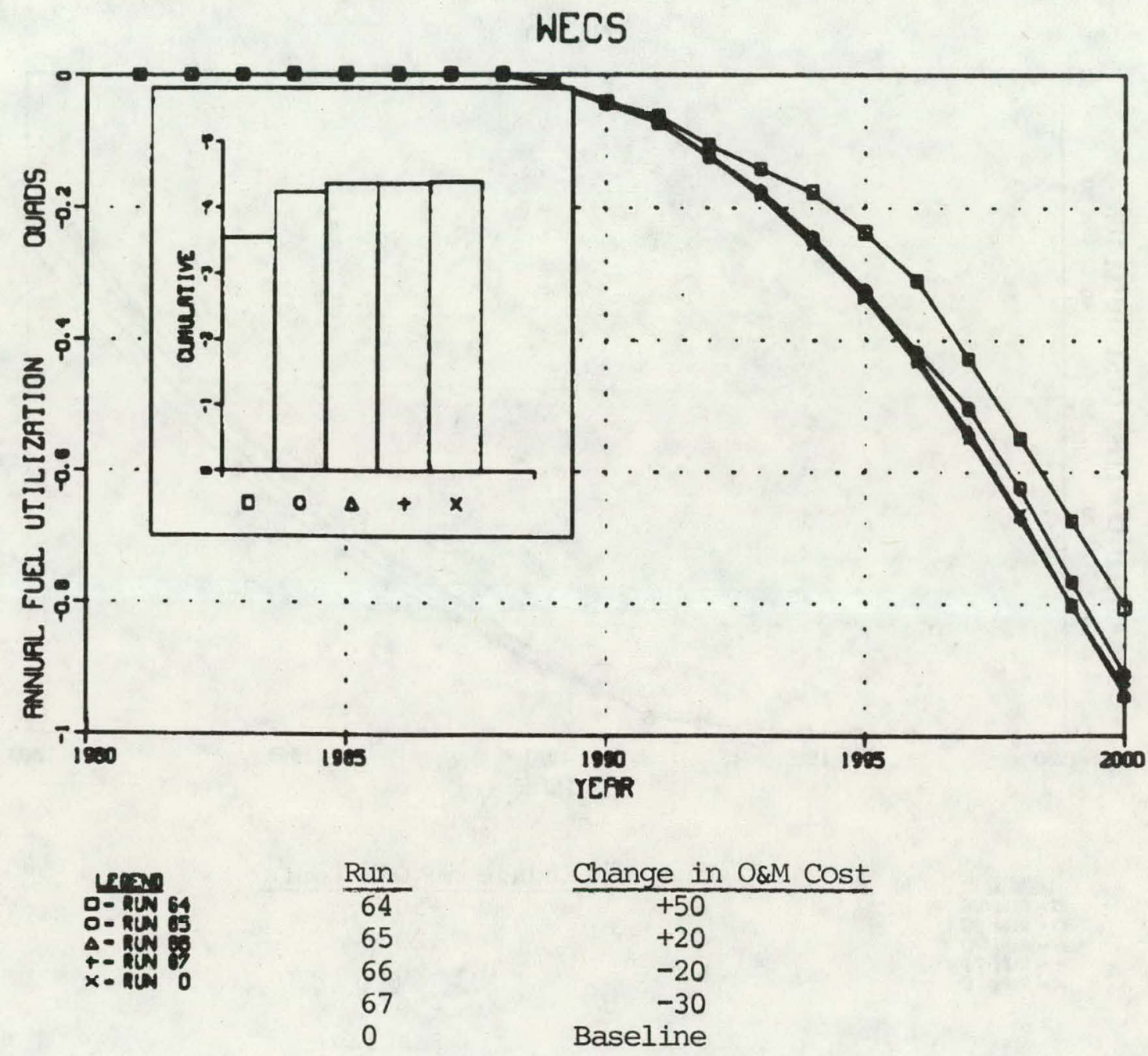

Figure 4-23. WECS, \% O\&M Costs Change vs. Annual Fuel Utilization 


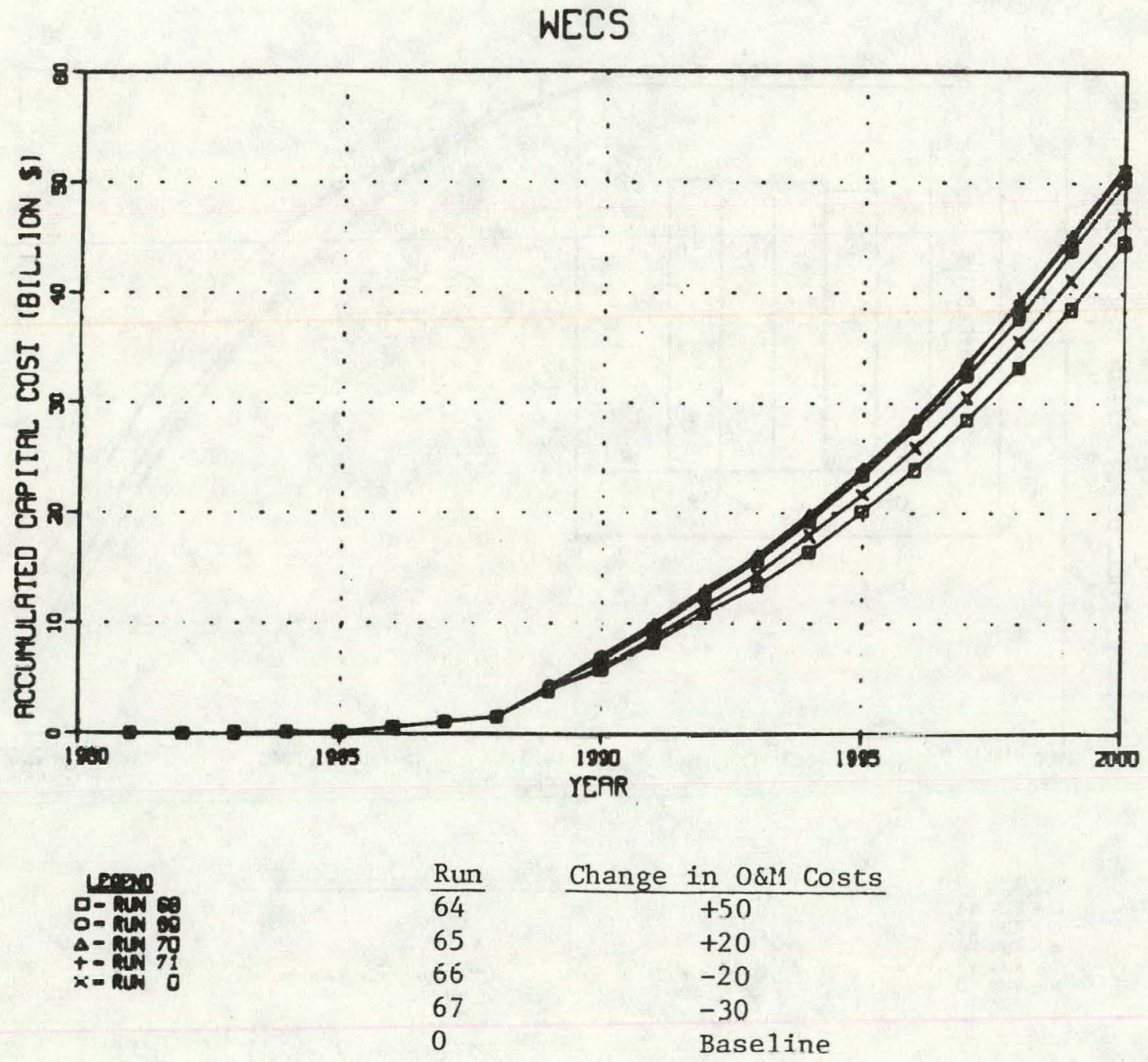

Figure 4-24. WECS, \% O\&M Costs Change vs. Accumulated Capital Costs 
WECS

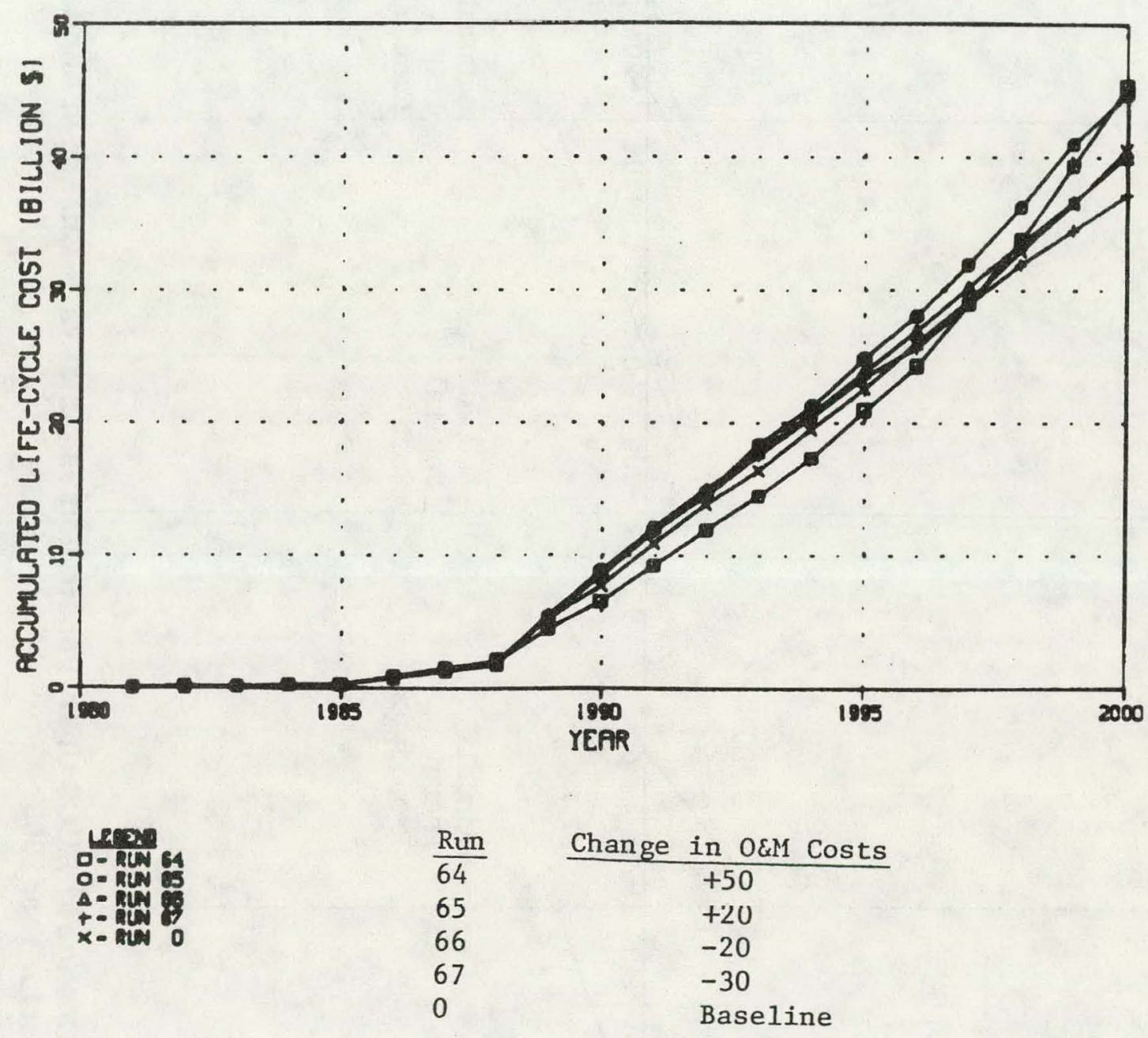

Figure 4-25. WECS, \% O\&M Costs Change vs. Accumulated Life-Cycle Cost 


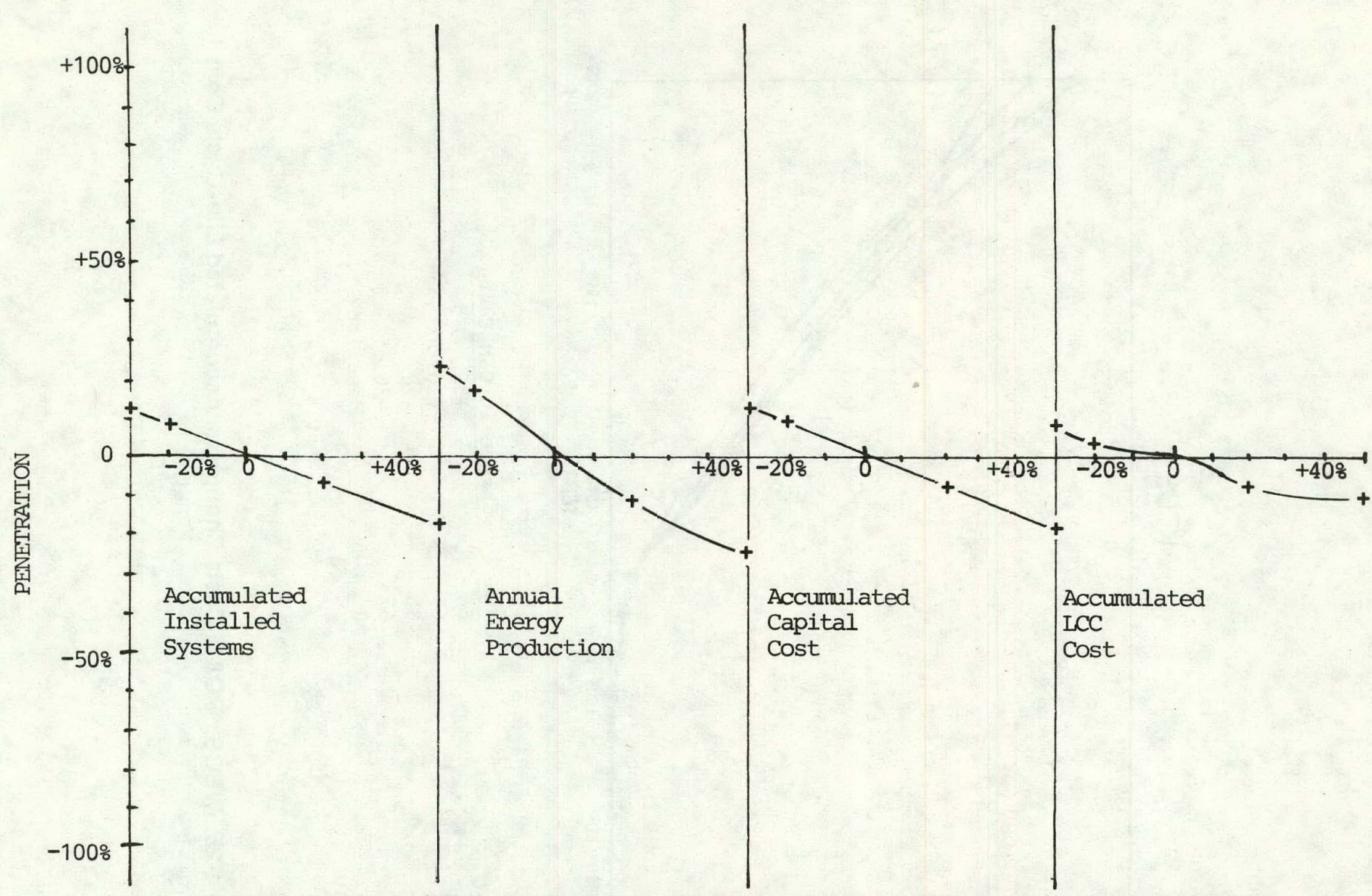


The WECS utility sensitivity to O\&M cost was relatively low; however, the nonlinear effect of including fuel savers in this group (see additional discussion of this effect in Section 3.5) are observable in Figs. 4-25 and 4-26.

\subsection{OTEC SYSTEM* PENETRATION VS. ANNUAL O\&M COST}

The sensitivity of OTEC system* technologies (see Table 2-2) penetration as a function of time to variation in annual O\&M cost of $-30 \%$ to $+50 \%$ is shown in Figs. 4-27 through 4-30. Figure 4-31 shows the percentage variation in penetration of the SPURR output parameters for the year 2000. The changes in the OTEC system technologies were done as a group in this analysis but could have been done individually; i.e., the changes were the same for each technology in this group as the technology entered the marketplace (see market entry dates in Table 2-1). The following is a summary of the resul ts:

\begin{tabular}{|c|c|c|c|c|}
\hline & $\begin{array}{c}\text { Acc. } \\
\text { Installed } \\
\text { Systems } \\
\end{array}$ & $\begin{array}{c}\text { Annual } \\
\text { Energy } \\
\text { Produced } \\
\end{array}$ & $\begin{array}{c}\text { Acc. } \\
\text { Capital } \\
\text { Cost }\end{array}$ & $\begin{array}{l}\text { Acc. } \\
\text { LCC } \\
\text { Cost } \\
\end{array}$ \\
\hline $\begin{array}{l}\text { Type of } \\
\text { relationship }\end{array}$ & Nonlinear & Nonlinear & Nonlinear & Nonlinear \\
\hline Sense & Proper & Proper & Proper & Proper \\
\hline Sensitivity & $\begin{array}{l}\text { High } \\
3: 1\end{array}$ & $\begin{array}{l}\text { High } \\
3: 1\end{array}$ & $\begin{array}{l}\text { High } \\
3: 1\end{array}$ & $\begin{array}{l}\text { High } \\
3: 1\end{array}$ \\
\hline
\end{tabular}

As shown by the variation in capital cost, the discrete (discontinuous) behavior of penetration variables is observed (see Fig. 4-31). It is due to the small number of large plants (400 MW) that were built since the market entry of OTEC (1995). In this case, a 20\% decrease in annual $O \& M$ cost was sufficient to have additional plants built but a change to $-30 \%$ did not al ter the number of plants built by year 2000. The same was true over the range from 0 to $+20 \%$; however, the life-cycle cost did reduce somewhat over this same range (see Fig. 4-31). Thus, the sensitivity to O\&M seems high (when viewed as a percentage change from baseline) due to the small number of large plants that have been built.

*Includes OTFC, electric generation and ammonia plants (see Table 2-2). 


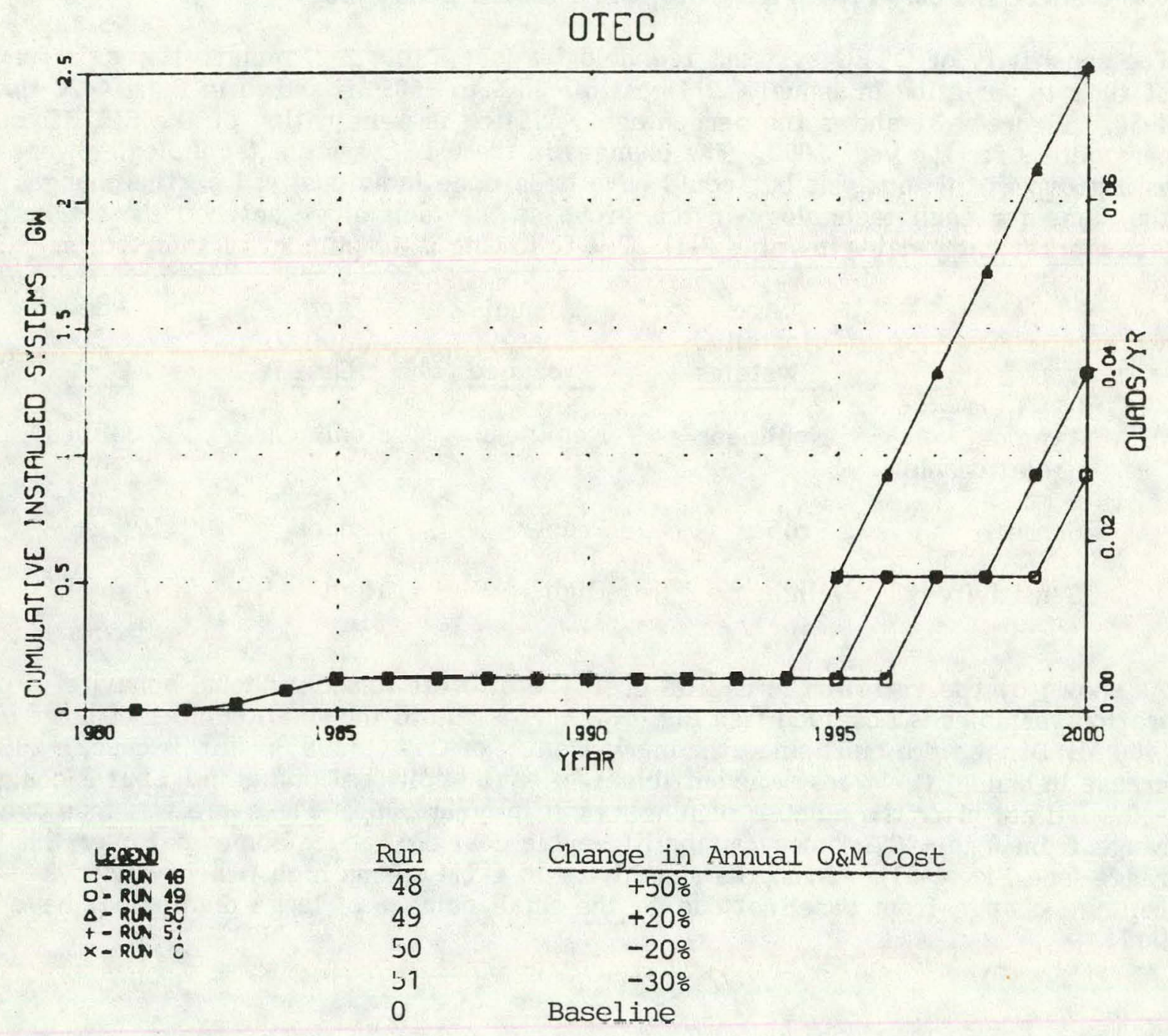

Figure 4-27. OTEC, \% Annual O\&M Costs Change vs. Cumulative Installed Cost 


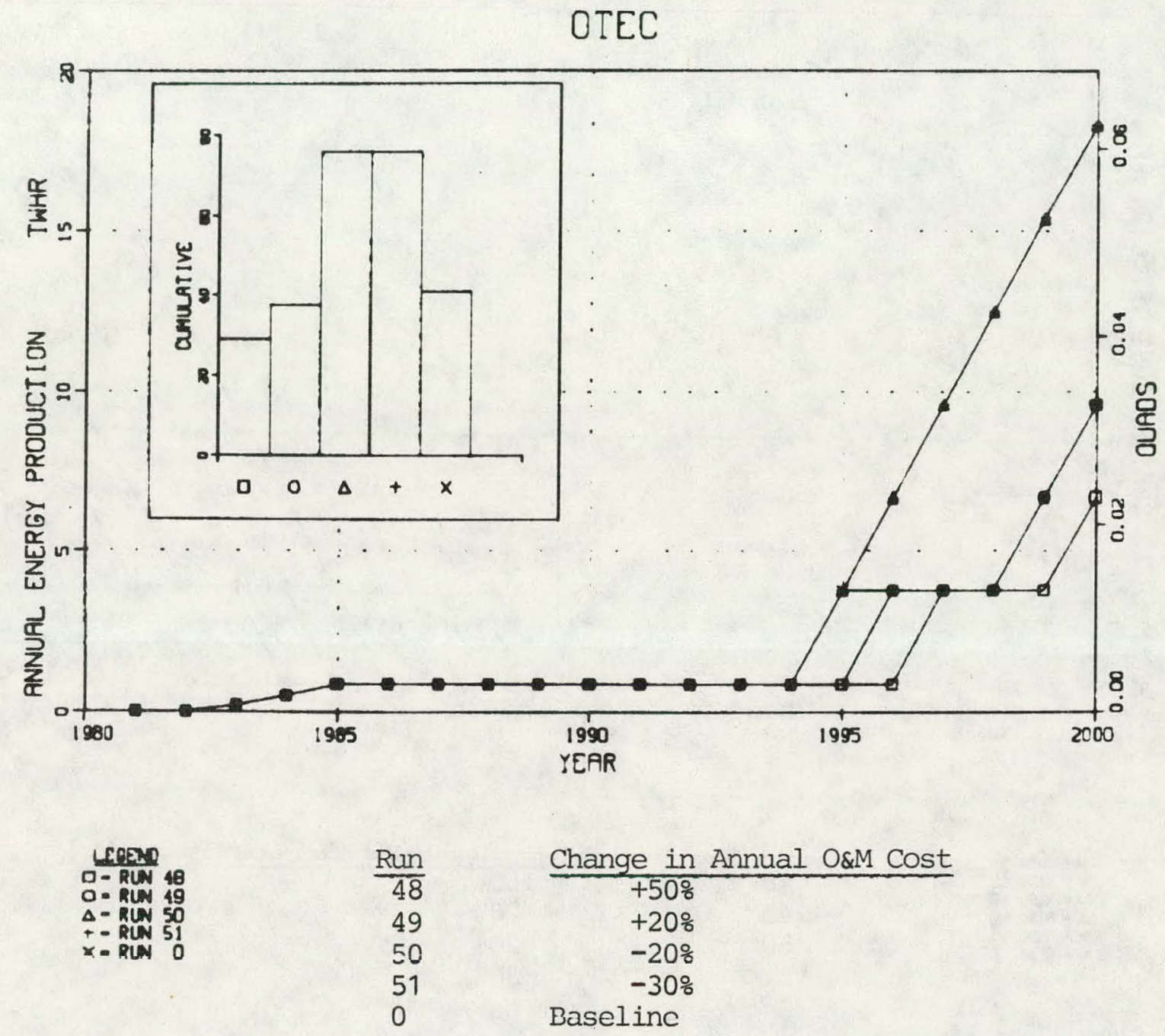

Figure 4-28. OTEC, \% Annual O\&M Costs Change vs. Annual Energy Production 


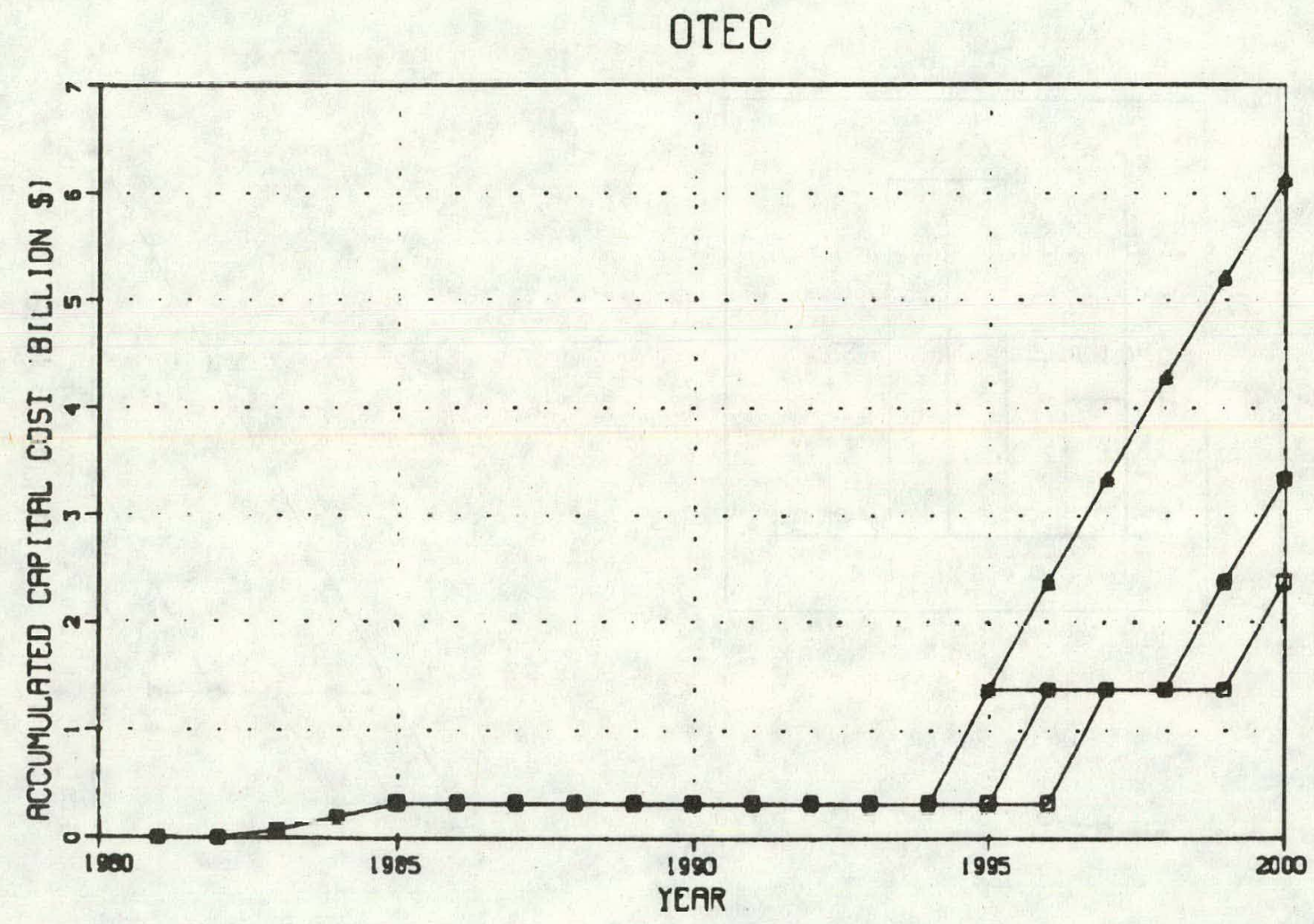

\begin{tabular}{|c|c|c|}
\hline 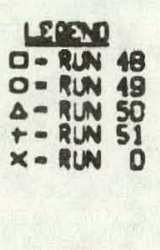 & $\begin{array}{l}\frac{R u n}{48} \\
49 \\
50 \\
51 \\
0\end{array}$ & $\begin{array}{l}\text { Change in Annual O\&M Cost } \\
+50 \% \\
+20 \% \\
-20 \% \\
-30 \% \\
\text { Baseline }\end{array}$ \\
\hline
\end{tabular}

Figure 4-29. OTEC, \% Annual O\&M Costs Change vs. Accumulated Capital Costs 
OTEC

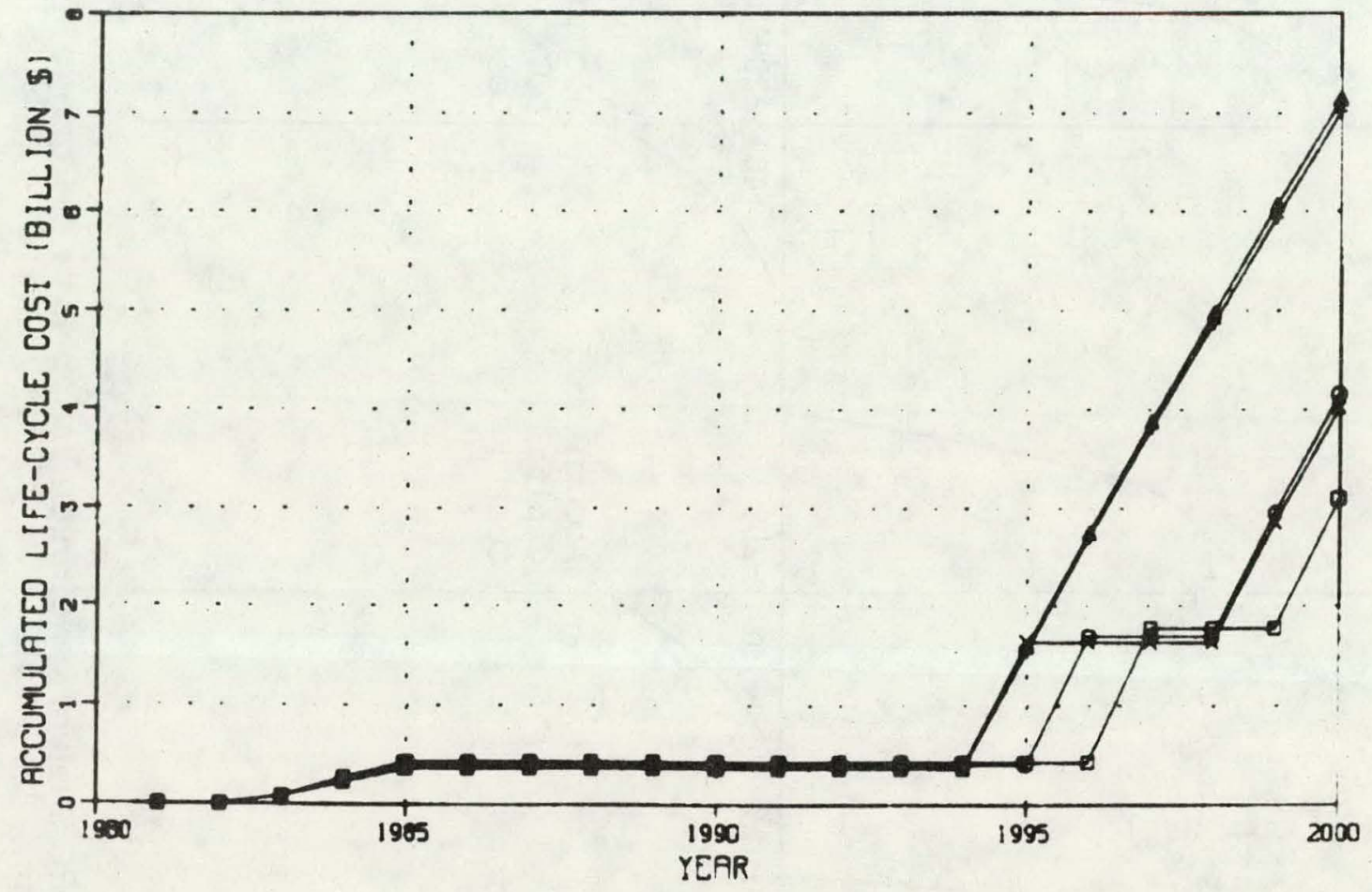

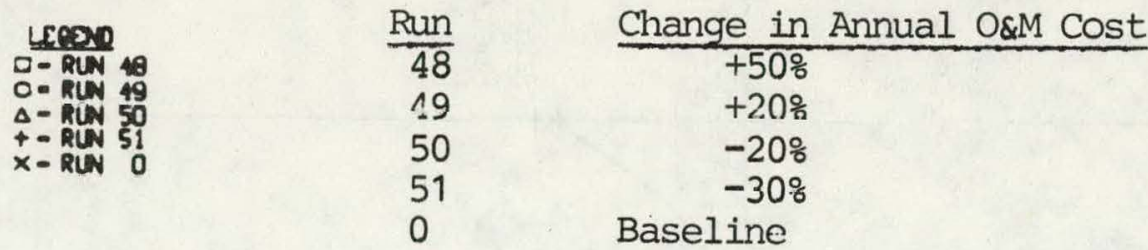

Flgure 4-30. OTEC, \% Annual O\&M Costs Change vs. Accumulated Life-Cycle Costs 


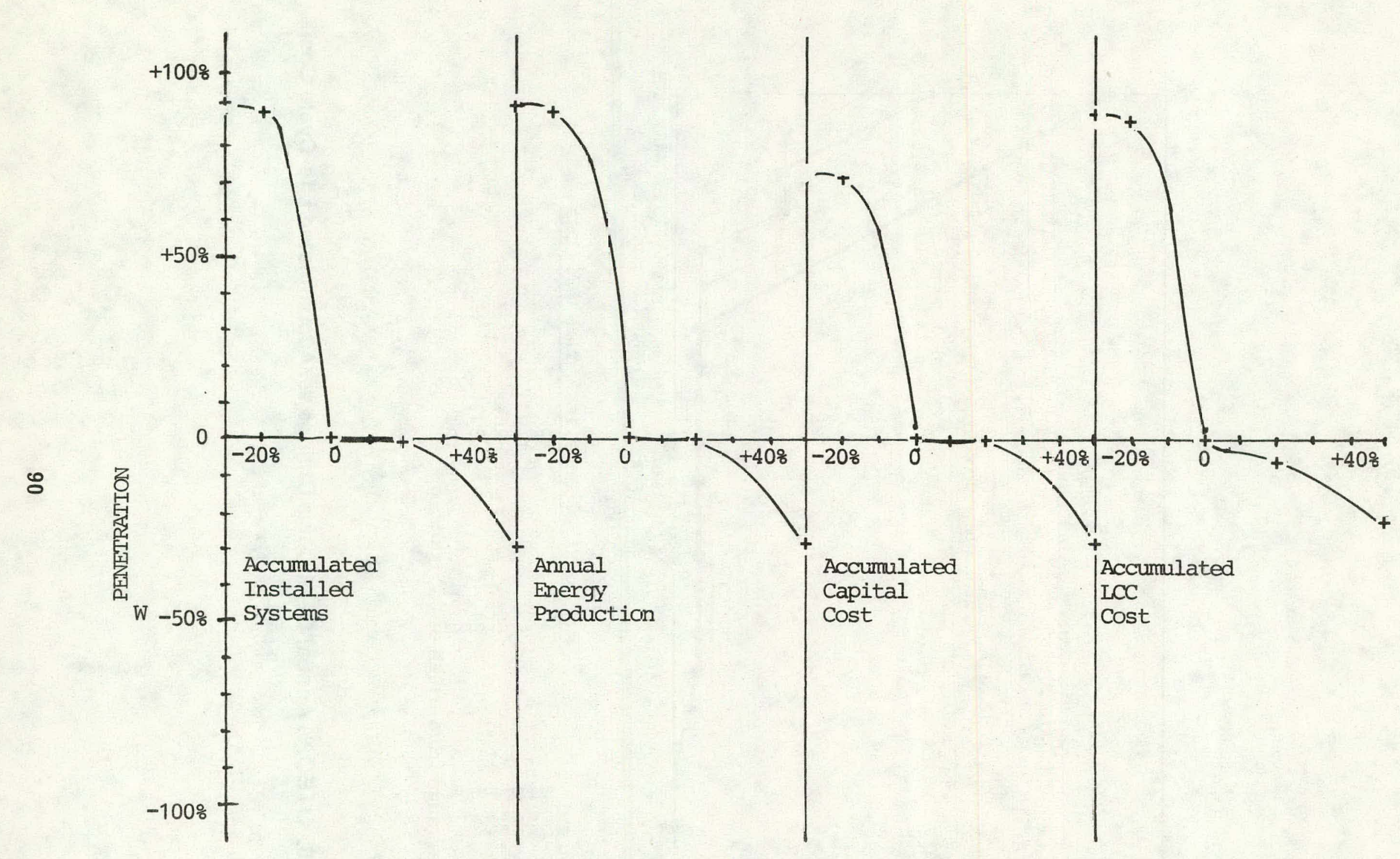

Figure 4-31. \% Change in OTEC System Penetration Variables vs. \% Change in Annual O\&M Cost for Year 2000 


\section{SECTION 5.0}

\section{BIOMASS FUEL COST SENSITTVITY ANALYSIS}

Biomass fuel cost was varied in each SPURR utility sector to evaluate the effects on the following SPURR output parameters:

- accumulated installed systems (million $\mathrm{ft}^{2}$ or $\mathrm{GW}$ ),

- annual energy production (TWh or quads/yr),

- accumulated capital cost (\$), and

- accumulated life-cycle cost (\$).

Accumulated installed systems is a measure of the number of systems installed. Annual energy production measures the total energy production of all plants in a specific year. Accumulated capital cost is the total capital cost of all plants built by a specific year. Accumulated federal expense is the amount of federal money lost due to tax credits. Annual fuel utilization measures the amount of fuel burned. Accumulated life-cycle cost is the total life-cycle cost of systems installed at that time and includes capital cost, O\&M, and fuel cost over the lifetime of the plant.

The data in this section are presented in two ways: (1) variation of penetration (in real units) as a function of time (1980 to 2000) and (2) percentage change from baseline scenario (penetration) versus percentage change in capital cost. Biomass systems showed low sensitivity (ratio of percentage change in penetration versus percentage change in capital cost) to changes in fuel cost.

In addition to displaying the data, a qualitative and quantitative analysis of the results is provided for three criteria: type of relationship, sense, and sensitivity. The type of relationship indicates whether the change in penetration was linear or nonlinear with respect to fuel cost. For biomass the change was linear. Sense attempts to evaluate the direction of change in penetration with respect to intuitive feel about penetration; i.e., if fuel cost increases, one feels that fewer systems should be built, or vice versa. This analysis of sense is looking for obvious errors in the SPURR methodology. For biomass the sense was "proper." The final evaluation uses sensitivity in a qualitative (high, low, moderate, none) and a quantitative sense (if change was linear) by reporting the approximate proportionality of the change in penetration with the change in fuel cost. The sensitivities range from a high of $0.7: 1$ to a low of $0.2: 1$.

\section{BIOMASS UTUITY AND SYNTHETIC FUELS PENETRATION VS. FUEL COST}

The sensitivity of biomass utility and synthetic fuels technology penetration as function of time to variation in feedstock cost of $-10 \%$ to $+20 \%$ is shown in Figs. $5-1$ through $5-4$. Figure 5-5 shows the percentage variation in penetration of the SPURR output parameters for the year 2000. The changes in the biomass technologies were done as a group in this analysis but could have been done individually; i.e., the changes were the same for each technology in this group as the technology entered the marketplace (see market entry dates in Table 2-1). The following is a summary of the results: 


\section{BIOMASS}

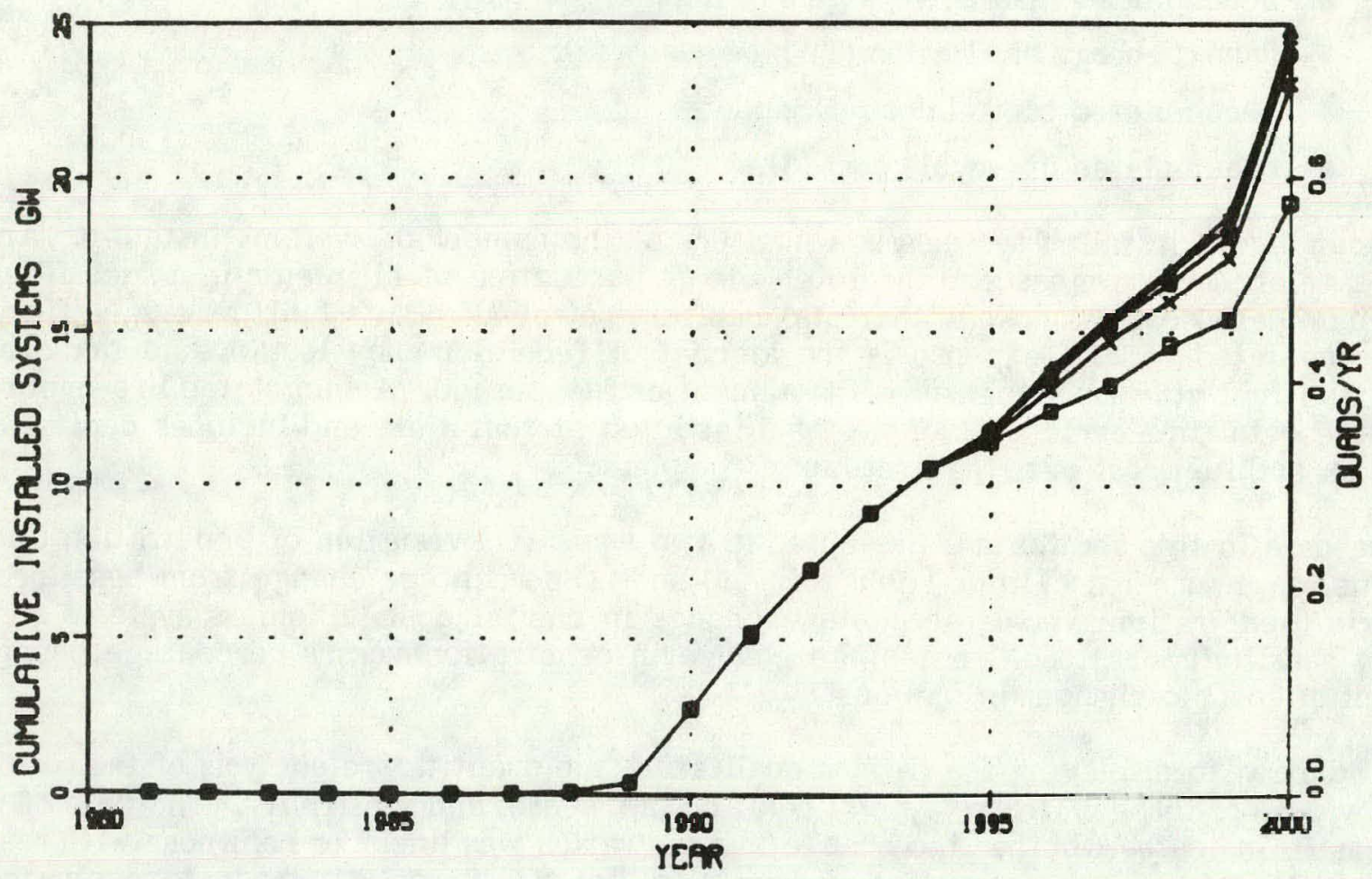

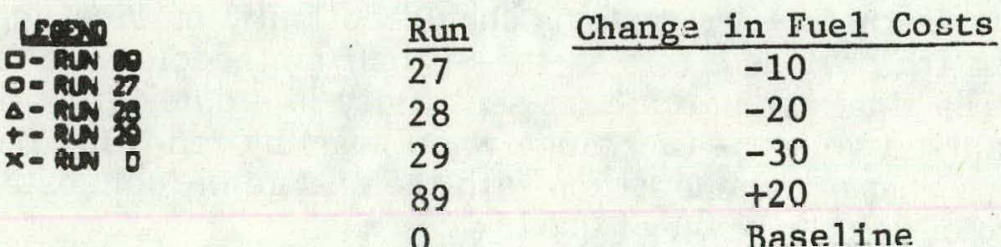

Figure 5-1. Biomass, \% Fuel Costs Change vs. Cumulative Installed Systems 
BIOMASS

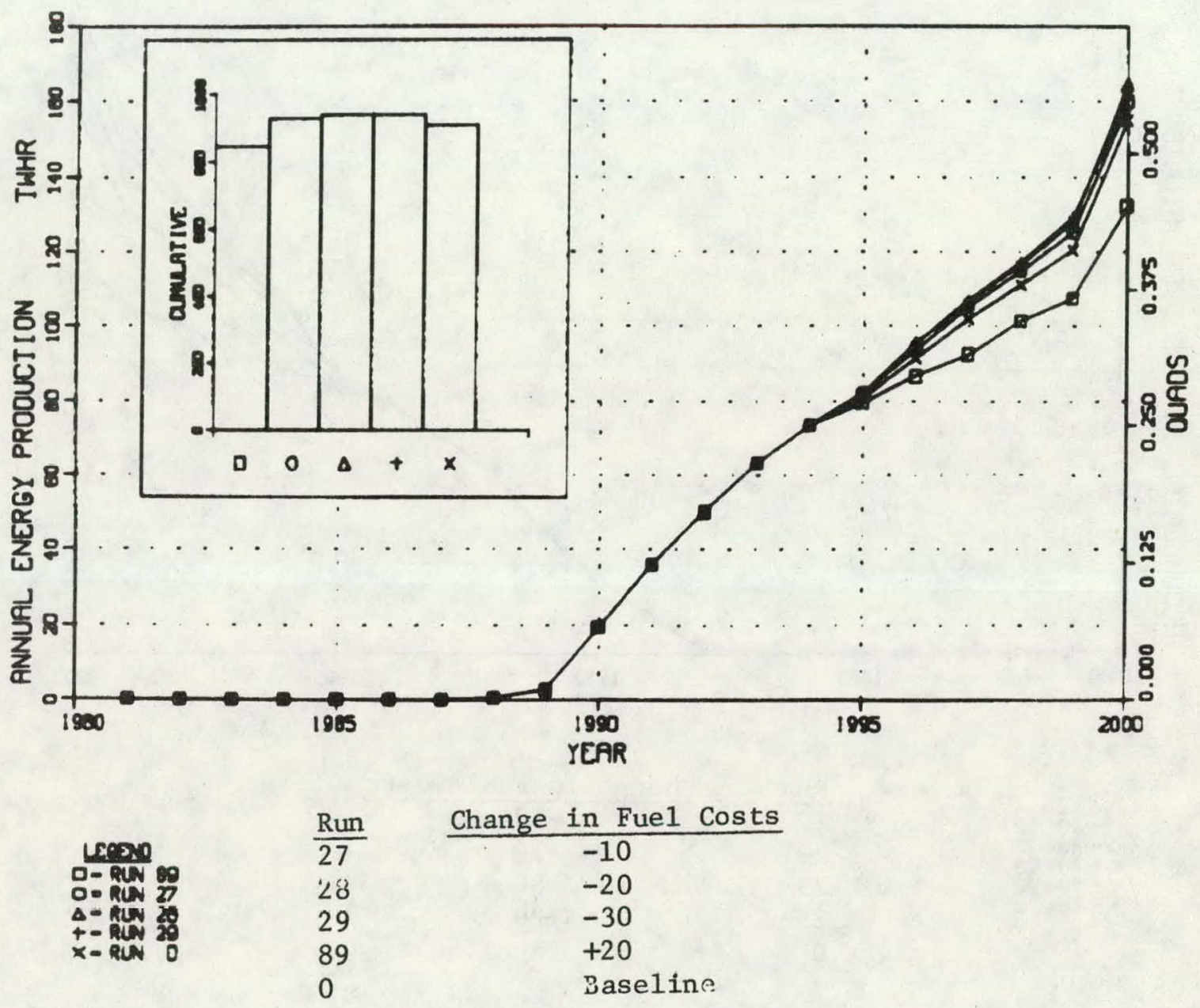

Figure 5-2. Biomass, \% Fuel Costs Change vs. Annual Energy Production 


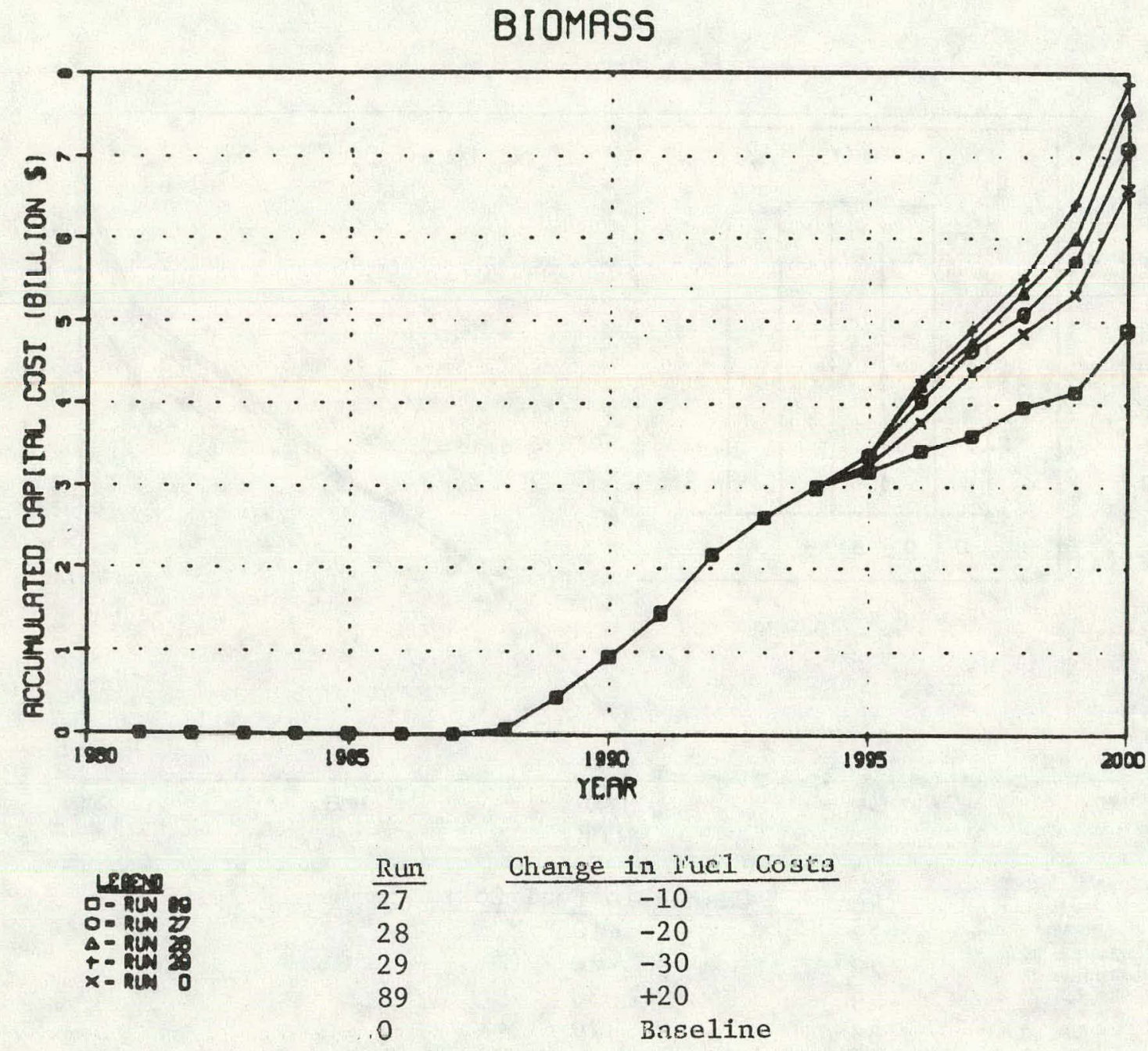

Figure 5-3. Biomass, $\%$ Fuel Costs Change vs. Accumulated Capital Cost 
BIOMASS
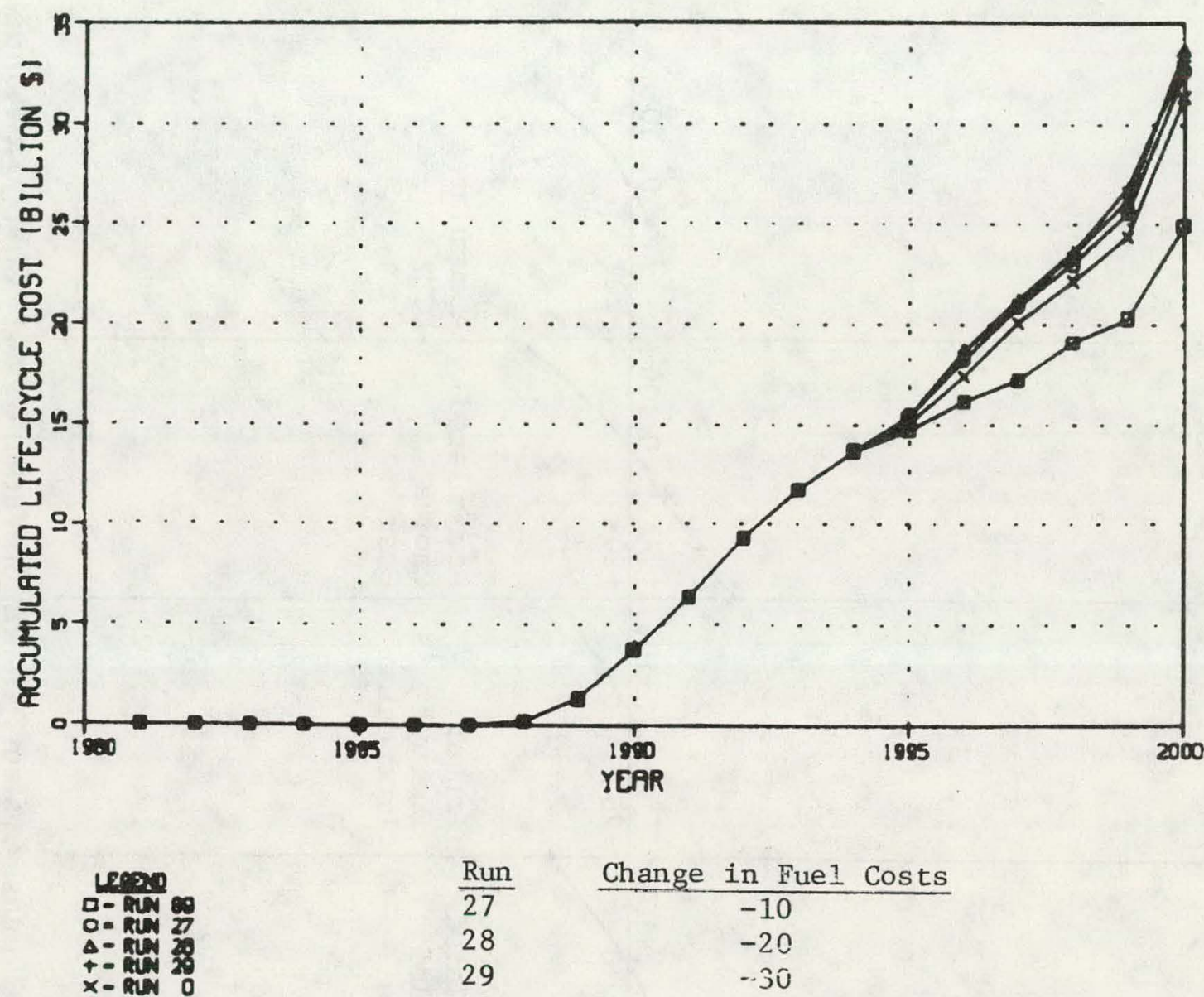

Run Change in Fue1 Costs

27

28

29

89

0

$-10$

$-20$

$-30$

$+20$

Baseline

Figure 5-4. Biomass, \% Fuel Costs Change vs. Accumulated Life-Cycle Cost 


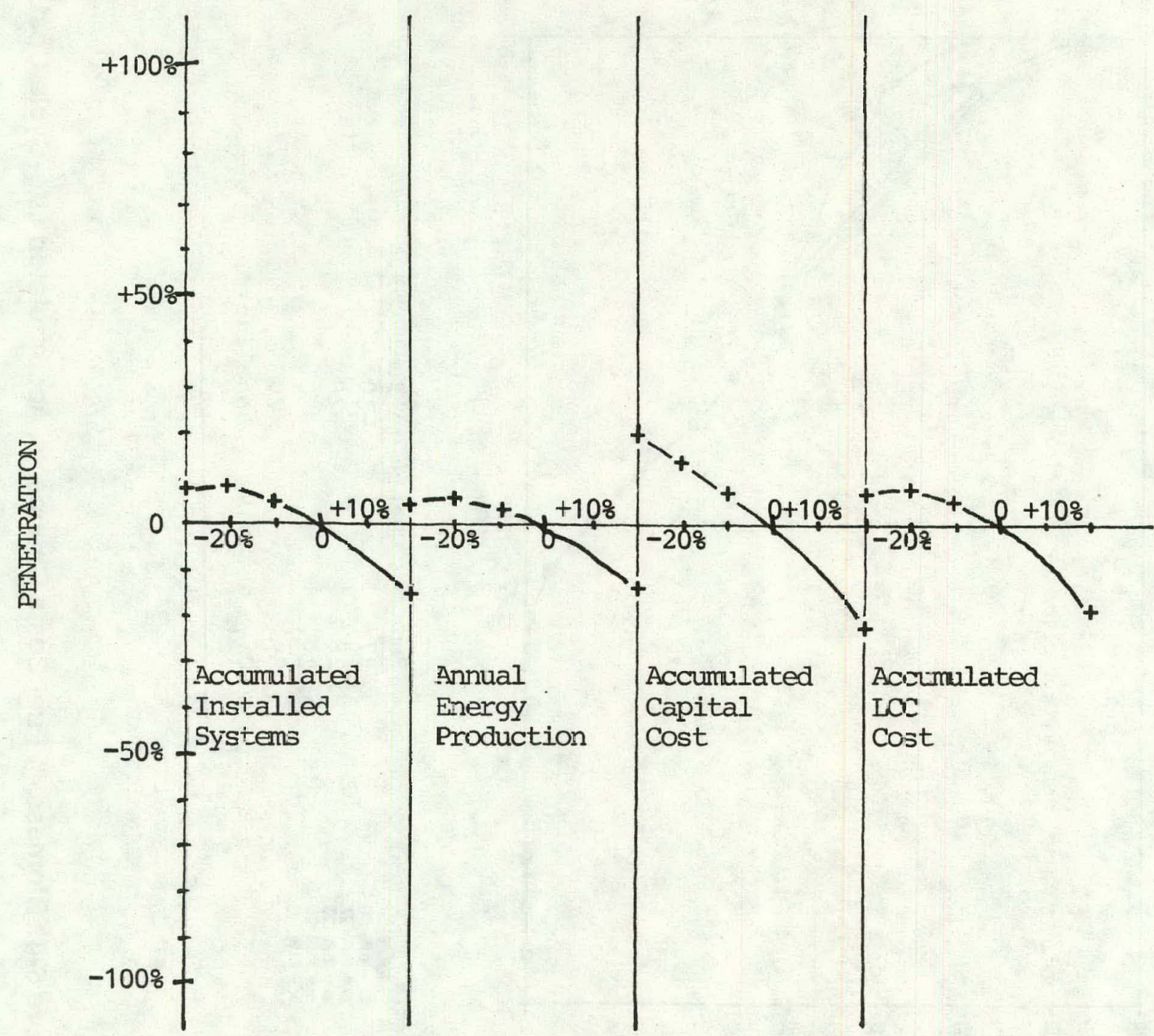

Figure 5-5. \% Change in Biomass System Penetration Variables vs. \% Change in Annual Fuel Cost for Year 2000 


$\begin{array}{lllll} & \begin{array}{c}\text { Acc. } \\ \text { Installed } \\ \text { Systems }\end{array} & \begin{array}{c}\text { Annual } \\ \text { Energy } \\ \text { Produced }\end{array} & \begin{array}{c}\text { Acc. } \\ \text { Capital } \\ \text { Cost }\end{array} & \begin{array}{r}\text { Acc. } \\ \text { LCC } \\ \text { Cost }\end{array} \\ \begin{array}{c}\text { Type of } \\ \text { relationship }\end{array} & \begin{array}{c}\text { Linear, } \\ \text { inverse }\end{array} & \begin{array}{c}\text { Linear, } \\ \text { inverse }\end{array} & \begin{array}{c}\text { Linear, } \\ \text { inverse }\end{array} & \text { Linear } \\ \text { Sense } & \text { Proper } & \text { Proper } & \text { Proper } & \text { Proper } \\ \text { Sensitivity } & \text { Low } & \text { Low } & \text { Low } & \text { Low } \\ & 0.3: 1 & 0.1: 1 & 0.6: 1 & 0.1: 1\end{array}$

Biomass sensitivity to fuel cost was relatively low. 
SEPI* 


\section{SECTION 6.0}

\section{CONCLUSIONS}

Sensitivity analysis was performed on the agricultural and industrial process heat and utility market sectors of the SPURR model which utilized the DPR baseline scenario. The objective of this sensitivity analysis is to determine if variations in solar system capital cost, operation and maintenance cost, and fuel cost (for biomass only) correlate with "common sense" and do not offend basic intuition. In general, this effort is part of a much larger issue: validation of SPURR.

Variations of the factors were evaluated for the following output parameters (others are available):

- accumulated installed systems,

- annual energy production,

- accumulated capital cost, and

- accumulated life-cycle cost.

An analysis of the results is presented for three criteria: (1) type of relationship, (2) sense, and (3) sensitivity.

The type of relationship indicates whether the change in penetration is linear or nonlinear with respect to a change in a given variable, while sense attemp ts to evaluate the direction of change with respect to an intuitive feeling about penetration. Sensitivity is the ratio of percentage change in penetration versus a percentage change in a given factor (e.g., capital cost).

\subsection{CAPITAL COST}

Capital cost was varied while all other parameters remained constant. The technologies showing high $(>1: 1)$ sensitivity were process heat (solar thermal), solar thermal (utilities), photovol taics, and OTEC.

An inverse linear variation affecting the accumulated installed systems and annual energy production was observed in process heat systems. As capital cost decreases, the number of solar units buil t increases. Consequently, the number of "installed systems" and "annual energy production" increase.

The nonlinear effect in accumulated capital cost and accumulated life-cycle cost is a result of two opposing functions: market share and capital cost. Accumulated capital cost increases due to higher market shares (when solar costs are reduced) but decreases due to the reduced capital cost of each solar unit.

Any change in capital costs over the study range $( \pm 60)$ reduces accumulated capital and accumulated life-cycle costs by the year 2000 .

A nonlinearity is observed in accumulated life-cycle cost of solar thermal utility technologies. This is due to the inclusion of fuel-saver systems. The life-cycle cost of a fuel-saver system is negative; i.e., it saves more fuel cost than the cost to build it. 
This effect is also predominant in photovoltaic utility technologies. Photovoltaic systems show a high, inverse proportional sensitivity to changes in capital cost.

Wind energy conversion systems (WECS) exhibit a low sensitivity to changes in capital cost but show significant effects of fuel savers in accumulated capital costs and accumulated life-cycle costs. Capital costs are the major cost in these systems. Fuel costs are zero and operating and maintenance costs are negligible.

The penetration of biomass systems is relatively insensitive to changes in capital costs. Consistent behavior (linear-inverse proportionality) is observed across all penetration variables.

Ocean Thermal Energy Conversion (OTEC) systems are extremely sensitive on a percentage hasis. This is due to the small number of plants built (a change of one plant when two are bull ( resul ts in a 50\%, change in capital cooto). SPURR OTEC plants also hrvo late market entry dates.

\subsection{OPERATING AND MANTTENANCE COSTS}

Annual operating and maintenance costs were varied in each SPURR sector to evaluate the effects on the stated parameters. The only technology exhibiting a high sensitivity was OTEC. This was attributed to the relatively small number of large plants that had been buil $t$ in the simulation.

Overall, the analysis of penetration of solar technologies shows a variation of less than $10 \%$ by the year 2000 . These resul ts should be qualified in light of the uncertainty surrounding estimates of O\&M cost for future technologies in the SPURR data base.

Process heat systems and solar thermal utility technologies are insensitive to changes in $O \& M$ costs and do not affect accumulated life-cycle costs.

Photovol taic utility technologies are moderately sensitive to O\&M cost and the effect is linear. The nonlinear nature of accumulated life-cycle costs is due to the inclusion of fuel savers.

O\&M costs are large enough to significantly reduce accumulated life-cycle costs when O\&M costs are reduced in photovoltaic systems.

WECS systems exhibit low sensitivity and nonlinear effects associated with fuel savers.

Biomass technologies are insensitive to changes in $0 \& M$ costs. The critical parameters in this case are capital and fuel costs.

\subsection{PUEL COST: BIOMASS}

The effects on penetration of varying biomass fuel cost are linear. Sensitivity ratios are low, ranging from $0.7: 1$ to $0.2: 1$. 


\subsection{SUMMARY.}

This study has practical applications for engineering improvements in solar technologies and is useful as a planning tool in the $R \& D$ allocation process. The resul ts of the analysis for the variables studied indicate that SPURR simulation is consistent with intuitive effects for these variables.

Further research efforts will be conducted after a coding problem encountered in the output reports of the SHACOB component is corrected. A similar analysis will be performed in this sector.

SPURR must also be modified so that variations in system lifetime can be included. Presently, sensitivity analysis of system lifetime will produce resul ts that are counterintuitive and are the result of the economic equations in the model that cannot handle systems with different lifetimes. Comparisons between systems require a common time basis, including a common year for cost comparison and a common operating period. "This is a consequence of the annualization of the energy cost into a stream of payments that is constant throughout the lifetime"[5] . 


\section{SEPI}


$i_{i=0}^{i}$

\section{SECTION 7.0}

\section{REPERENCES}

1. MITRE Corporation, METREK Division. A System for Projecting the Utilization of Renewable Resources, SPURR Methodology. ERHQ/2322-77/4. McLean, VA: MITRE Corporation; Sept. 1977.

2. Drescher, R. D.; Rebibo, K. 1978. SPURR Agricultural and Industrial Process Heat Component-Program Methodology and Documentation, Working Paper. Project No. 1585B. MeLean, VA: MITRE Corporation; March 10, 1978.

3. Coluzzi, M.; Rebibo, K. SPURR Utility Component Program Methodology and Documentation, Working Paper. Project No. 1585B. MeLean, VA: MITRE Corporation; May 1978.

4. MITRE Corporation, METREK Division. Solar Energy: A Comparative Analysis to the Year 2020. ERHQ/2322-78/1. McLean, VA: MITRE Corporation; Mar. 1978.

5. Doane, J. W.; OToole, R. P.; Chamberlain, R. G.; Bos, P. B.; Maycock, P. D. The Cost of Energy from Utility-Owned Solar Electric Systems, A Required Revenue Methodology for ERDA/EPRI Evaluations, ERDA/JPL-1012-76/3. Pasadena, CA: Jet Propulsion Laboratory; June 1976. 


\begin{tabular}{|c|c|c|}
\hline $\begin{array}{c}\text { Document Control } \\
\text { Page }\end{array}$ & \begin{tabular}{|l|l|}
$\begin{array}{c}\text { 1. SERI Report No. } \\
\text { TR-353-280 }\end{array}$ & 2. NTIS Accession No. \\
\end{tabular} & 3. Recipient's Accession No: \\
\hline \multirow{2}{*}{\multicolumn{2}{|c|}{$\begin{array}{l}\text { 4. Title and Subtitle } \\
\text { A Sensitivity Analysis of SPURR }\end{array}$}} & $\begin{array}{l}\text { 5. Publication Date } \\
\text { Aprif } 1980 \\
\end{array}$ \\
\hline & & 6. \\
\hline \multicolumn{2}{|c|}{$\begin{array}{l}\text { 7. Author(s) } \\
\text { Robert E. Witholder }\end{array}$} & 8. Performing Organization Rept. No. \\
\hline \multicolumn{2}{|c|}{$\begin{array}{l}\text { 9. Performing Organization Name and Address } \\
\text { Solar Energy Research Institute } \\
1617 \text { Cole Boulevard } \\
\text { Golden, Colorado }\end{array}$} & 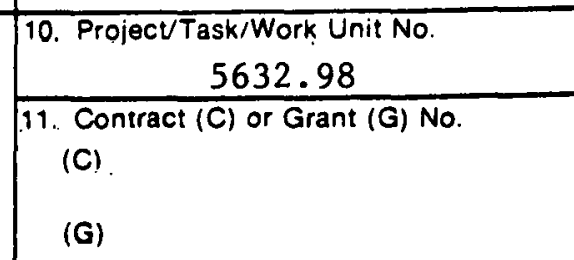 \\
\hline \multirow{2}{*}{\multicolumn{2}{|c|}{ 12. Sponsoring Organization Name and Address. }} & $\begin{array}{l}\text { 13. Type of Report \& Period Covered } \\
\text { Technical Report }\end{array}$ \\
\hline & & 14. \\
\hline \multicolumn{3}{|l|}{ 15. Supplementary Notes } \\
\hline \multicolumn{3}{|c|}{$\begin{array}{l}\text { 16. Abstract (Limit: } 200 \text { words) } \\
\text { The Solar Energy Research Institute has conducted a limited sensitivity analysis } \\
\text { on a "System for Projecting the Utilization of Renewable Resources" (SPURR) } \\
\text { developed by the MITRE Corporation. The study utilized the "Domestic Pollcy } \\
\text { Review" scenario for SPURR agricultural and industrial process heat and utility } \\
\text { market sectors. This sensitivity analysis determines whether variations in solar } \\
\text { system capital cost, operation and maintenance cost, and fuel cost (biomass only) } \\
\text { correlate with intuitive expectations. The results of this effort contribute to } \\
\text { a much larger issue: validation of SPURR. Such a study has practical applications } \\
\text { for engineering improvements in solar technologies and is useful as a planning } \\
\text { tool in the R\&D allocation process. }\end{array}$} \\
\hline \multicolumn{3}{|c|}{$\begin{array}{l}\text { a. Descriptors SPURR Mode1; Domestic Policy Review; Statistical Models; Cost; } \\
\text { Market Penetration; Biomass; Wind Energy Conversion Systems; Agricultural Pro- } \\
\text { cess Heat; Industrial Process Heat; Solar Heating; Solar Cooling; Public } \\
\text { b. Identifiers/Open-Ended Terms Utilities; Simulation; Ocean. Thermal Energy Conversion; } \\
\text { Photovoltaic Cells; Solar Thermal Power Systems } \\
\text { c. UC Categories } \\
58 \mathrm{~b}\end{array}$} \\
\hline \multirow{2}{*}{\multicolumn{2}{|c|}{$\begin{array}{l}\text { 18. Availability Statement } \\
\text { National Technical Information Service } \\
\text { U.S. Department of Commerce } \\
5285 \text { Port Royal Road } \\
\text { Springfield. Virginta } 22161\end{array}$}} & \begin{tabular}{r|r} 
19. No. of Pages \\
114
\end{tabular} \\
\hline & & $\begin{array}{r}\text { 20. Price } \\
\$ 6.50\end{array}$ \\
\hline
\end{tabular}

